\title{
ALTERAÇÃO DA ESPESSURA DA FASE LIVRE DA GASOLINA SOB AÇÃO CO-SOLVENTE DO ETANOL
}

MARIA ANISIA DE CASTRO PEREIRA

Orientador: Dr. Everton de Oliveira

DISSERTAÇÃO DE MESTRADO

COMISSÃO JULGADORA

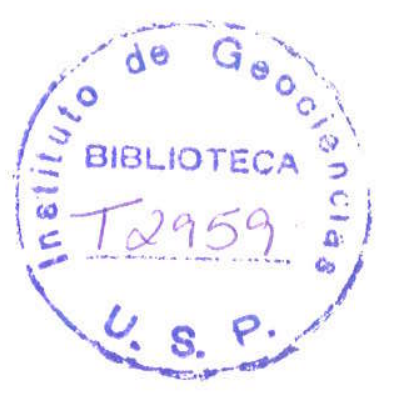

Nome

Presidente: Dr. Everton de Oliveira

Examinadores: Prof. Dr. Chang Hung Kiang

Prof. Dr. Uriel Duarte

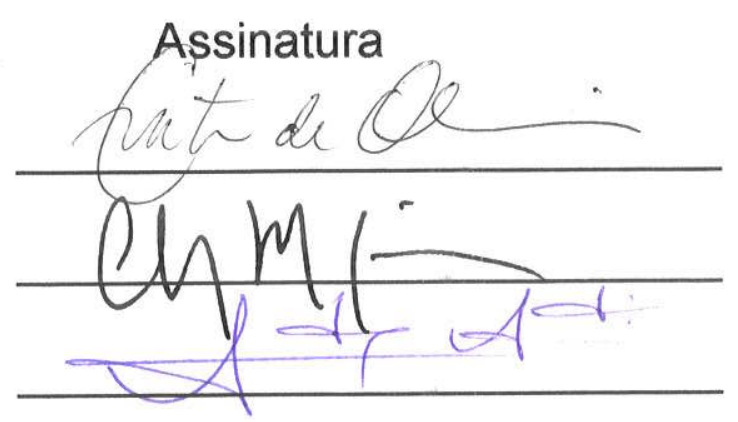

SÃO PAULO

2000 


\section{UNIVERSIDADE DE SÃO PAULO \\ INSTITUTO DE GEOCIÊNCIAS}

\section{ALTERAÇÃO DA ESPESSURA DA FASE LIVRE DA GASOLINA SOB AÇÃO CO-SOLVENTE DO ETANOL}
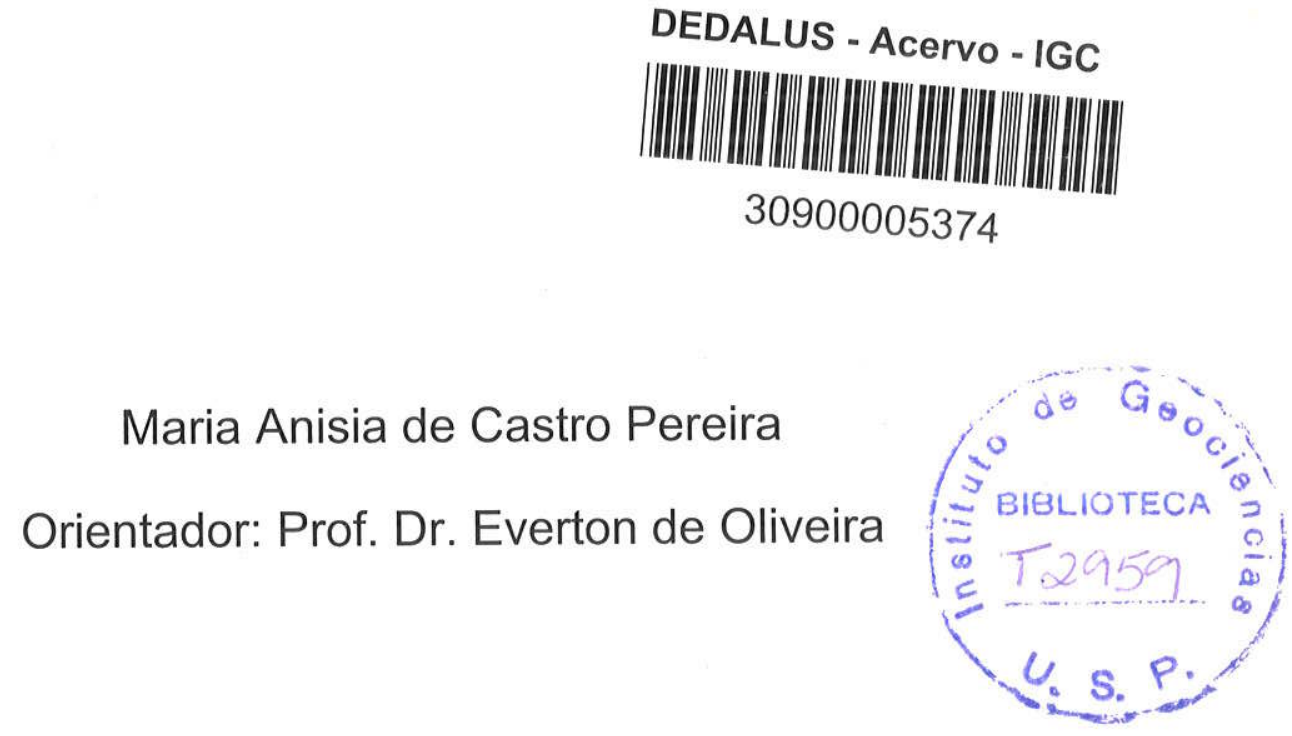

DISSERTAÇÃO DE MESTRADO

Programa de Pós-Graduação em Recursos Minerais e Hidrogeologia 
Para a melhor família do mundo, Epifânio, Helena, Fabinha, Nanda e Rui 
INDICE

AGRADECIMENTOS

RESUMO

ABSTRACT

INTRODUÇÃO

OBJETIVOS

Capítulo 1 - Elementos em Estudo

1.1 - Composição da gasolina.................................................................

1.1 .1 - Propriedades físico-químicas .............................................. 2

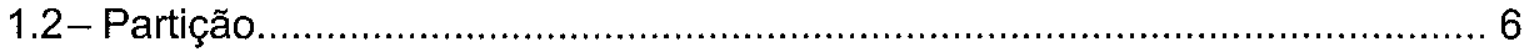

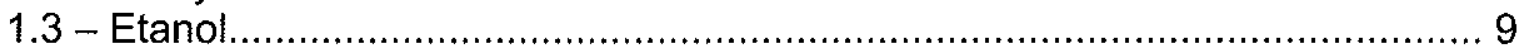

1.3.1- Co-solvência.................................................................. 9

1.4 - Diagrama pseudoternário............................................................. 11

Capítulo 2 - Material e Métodos ......................................................................... 13

2.1 - Montagem das Colunas .................................................................. 13

2.2 - Determinação das Zonas Saturada e Não Saturada ................................17

2.2.1 - Saturação por água ............................................................ 17

2.3 - Estimativa do nível de combustivel ............................................... 24

Capítulo 3 - Relações Microscópicas e Macroscópicas..............................................27

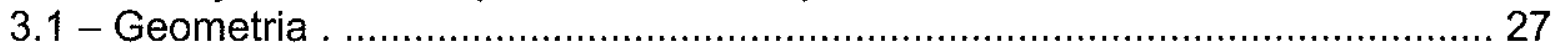

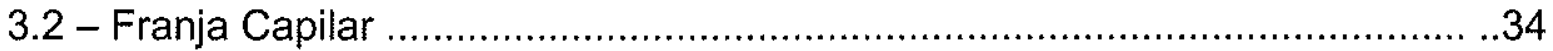

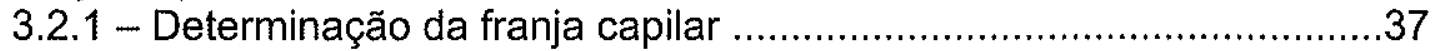

3.3 - Interação entre fluidos e franja capilar ..................................................38

3.3.1 - Gasolina no sistema monofásico ............................................38

3.3.2 - Gasolina no sistema plurifásico .........................................42

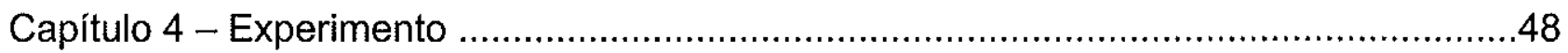

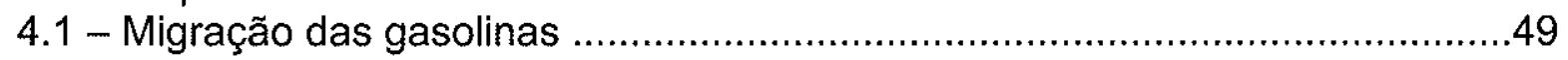

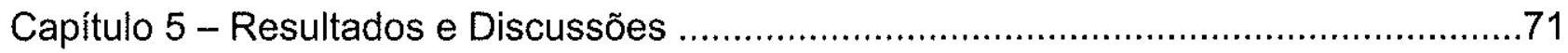

Capítulo 6 - Conclusões e Recomendações .........................................................79

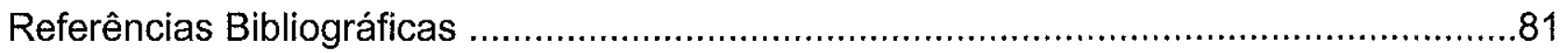




\section{Capítulo 1}

Figura 1.1 Distribuição de densidade para o sistema pseudo-ternário gasolina/água/etanol

(Oliveira, 1997)

Figura 1.2 Fases da gasolina no subsolo (modificado de Mackey e Cherry, 1989)

Figura 1.3 Diagrama pseudo-ternário para o sistema gasolina/água/etanol (Oliveira, 1997) 12

Capítulo 2

Figura 2.1 Esquema de montagem de uma coluna

Figura 2.2 Montagem completa dos sistemas, Coluna A e Coluna B 16

Figura 2.3 Acompanhamento da frente molhante e nivel d'água 16

Figura 2.4 Colunas com saturação completa $\quad 19$

Figura 2.5 Frente molhante uniforme $\quad 19$

Figura 2.6 Configuração microscópica no processo de drenagem (Gillham, 1984, adaptado) 22

Figura 2.7a) Definição de tensão interfacial

b) Equilibrio capilar em superfície esférica (Prigogine e Defay, 1996, in Dullien, 1992)

Figura 2.8 Rebaixamento do nível d'água devido a injeção de gasolina pura, Coluna $A$

Figura 2.9 Rebaixamento do nível d'água devido a injeção de E-24, Coluna B

\section{Capítulo 3}

Figura 3.1 a) Forma de anel pendular e b) ponte pendular para água (Dullien, 1992)

Figura 3.2 a) Fluido não molhante, e b) fluido molhante

Figura 3.3 Contato entre dois fluidos e o sólido (Bear, 1979)

Figura 3.4 Mudança de molhabilidade pela influência do etanol (Oliveira, 1997)

Figura 3.5 Contato entre três fluidos e o sólido (Dullien, 1992)

Figura 3.6 Efeito da franja capilar na descarga de água subterrânea para águas superficiais a) 35

antes da chuva, e b) imediatamente após a chuva (Gillhan, 1984)

Figura 3.7 Efeito da franja capilar em resposta ao nivel d'água em áreas de topografia irregular

(Gillhan, 1984)

Figura 3.8 a) tensões entre dois fluidos e o sólido, e b) entre três fluidos e o sólido (Wilson, 1992) 39

Figura 3.9 Efeito da posição do menisco em poros de diferentes tamanhos (Mod. de Dullien, 1992) 43

Figura 3.10 Decomposição de tensões no ponto $P$ (Dullien, 1992)

Figura 3.11 Redução da tensão interfacial da gasolina (Oliveira, 1997)

Figura 3.12 Redução da tensão interfacial da E-24 para o experimento

\section{Capítulo 4}

Figura 4.1 Sistema de injeção de combustíveis a) gasolina pura e, b) gasolina pura e E-24

Figura 4.2 Trapeamento de água (Chatzis e Dullien, 1983)

Figura 4.3 Considerações de van Genutchen e Brooks-Corey para Pressão capilar X saturação (Marinelli e Durford, 1996)

Figura 4.4 Conceito de Brooks-Corey para volume de combustível por espessura do poço (Marinelli e Durford, 1996).

Figura 4.5 a) relações entre pressões no meio poroso e no poço de monitoramento.

b) relações entre pressões nas Colunas

Figura 4.6 Detalhe do equilibrio da gasolina no meio poroso (Wilson, 1992) 56

Figura 4.7 Sequência de infiltração para gasolina pura

Figura 4.8 Formação da fase livre da E-24

Figura 4.9 Diferenças de espessuras entre a Coluna A e Coluna B

Figura 4.10 Relações de espessuras no meio poroso e poço de monitoramento (Abdul et al, 1989)

Figura 4.11 Elevação de combustivel, a) simultâneo à formação da fase livre, b) após formação

Figura 4.12 Elevação da fase livre ao redor do poço de monitoramento

Figura 4.13 Os niveis de combustíveis não obedecem o mesmo patamar

Figura 4.14a) Gráficos de acompanhamento da migração de gasolina pura

Figura 4.14b) Gráficos de acompanhamento da migração de gasolina pura

Figura 4.15 Diferença entre as espessuras dos combustiveis no PM e meio poroso

\section{Capítulo 5}

Figura 5.1 Ângulo de contato entre a gasolina pura e água $(\theta)$ no tubo capilar. Ângulo de contato 


\section{AGRADECIMENTOS}

Costumo dizer que esta dissertação valeria mais outras dez. Uma, sem dúvida, dedicada somente à amizade e pessoas incriveis que conhecí. Para todos os colegas e amigos, meu Axé. Que Deus os ilumine e guarde.

Ao Prof. Everton de Oliveira, meu orientador, no sentido expresso da palavra, meus agradecimentos.

Ao Departamento de Geologia Sedimentar e Ambiental do IGc/USP pelo ingresso no seu corpo discente.

A CAPES, fundação de fomento à minha bolsa de pesquisa.

Prof. Uriel Duarte pelo espaço do laboratório do CEPAS para montagem do experimento.

Cia. Brasileira de Petróleo Ipiranga nas pessoas dos Srs. Miguel di Ciurcio e Paulo Sérgio Bernardo pela oferta das gasolinas.

Hidroplan e todo corpo de geólogos pelo aprendizado prático.

Ao incentivo inicial: Profs. UFBA - Olivar de Lima e Lima, Joaquim Júlio e Ovídio Valadão e Prof. Alberto Pacheco (USP).

Obrigada a minha família postiça: Ricardo Ivan Trindade, Silvia Ferreira, Miguel Mané e Simone André, meus irmãozinhos queridos.

Valeu Valdeneide Silva e José Luiz Zoby pelas palavras doces naqueles momentos amargos.

Pela salvação nos momentos em que o word brigou comigo, Marcelo Rocha e Iraldo Jr.

Obrigada pela FORÇA: Fernando Saraiva, Fernando Oliveira, Carlos Araújo, Carbeny Capote, Eurélio Jr e aos técnicos Sílvio Luiz e Serginho Martins. Weber Werner, defensor dos pós-graduandos atrasados.

Toda a beleza das Figuras, à minha iniciação no Corel e pelo coração enorme, Mika Saito.

Todo o pessoal do apoio, sempre mais do que cordiais, Ana Paula Cabanal, Magali Rizzo, Nilva Souza, Tadeu Caggiano, João Vítor Maschi e ao pessoal da gráfica (Edmir, Claudionor, Henrique, Seu Zé).

Amigos maravilhosos e ótimos conselheiros também para assuntos extra acadêmicos, Douglas Bastianon, Jamile Dehaini, Francis Hager, Alejandra Penalosa, Carla Tolosa e Ana Berretta.

Aos companheiros de noitadas, sábados e domingos na Geo: Claudia Varnier e Vanderiei Vieira (segurança), Gaston Enrich e Lucelene Martins.

Agradecimentos mais que especiais a quatro pessoas maravilhosas: Cláudio dos Santos (Biotita), Artur (Geocron), Prof. Rafael Hipólyto e Prof. Fábio Taioli.

Profs. Amilton Sinatora (Poli-Mecânica), Caetano Juliani e Lilia Sant'Agostino ao apoio instrumental.

Sempre prestativos, Marquinhos, Clodoaldo e Manuel de Jesus Sousa da manutenção e Maurício da seção de compras. Janaína Ferreira e Lúcia Helena na arte do manejo da parte laboratoria!.

Aos queridissimos Arqueano-amigos: José George Silva, Eliane Almeida, loná Cunha, Rosemeire Bento, Patricia Santana, Clarini Fahel, Andreia Sanches e Walter de Araújo.

Ao Robson Luiz Góes Fonseca, meu anjo.

Amiga de sempre e sempre, Lília Pereira Lima e a família mais calorosa do mundo, Tios: Janete dos Santos, Emília de Castro, Nilson e Margarida Crusoé (e sua turma), Sara Machat e João de Castro.

Para a grande surpresa desta dissertação, um monte de carinho, George de Barros. 


\section{I - RESUMO}

A busca de soluções para poluição do ar conduziu a adição de álcool na composição da gasolina. Com esta medida além da redução da emissão de monóxido de carbono para atmosfera o uso de etanol diminui a fração de produtos derivados de petróleo no combustível. Entretanto quando estende-se o tema para o efeito desta mistura ao meio ambiente (solo e águas subterrâneas) algumas propriedades ainda são desconhecidas.

$\mathrm{Na}$ década de 90 a ciência mundial se voltou ao estudo do etanol devido a descoberta, por parte dos cientistas americanos dos danos causados pelo MTBE (methil tert-buthyl ether). Entretanto poucos trabalhos têm o etanol como alvo de pesquisas e formas de detecção no subsolo. O poço de monitoramento (PM) é uma das ferramentas aplicadas na verificação e quantificação da presença de gasolina no aqüífero. No entanto, os dados oriundos dos poços têm limitações, pois as condições de pressão, tensões e forças a que estão sujeitos os fluidos no meio poroso não são rebatidos para o interior do poço.

No experimento desenvolvido neste trabalho, há demonstração visual da diferença entre os ambientes de acumulação de gasolina em termos de espessuras entre as lâminas de gasolina no poço e meio contíguo, e a validade das equações aplicadas a correção desta diferença.

O experimento consistiu na simulação de vazamento de gasolina diretamente na franja capilar em 2 (duas) colunas de laboratório. A utilização de duas misturas diferentes, gasolina pura e E-24 (24\% em volume de etanol), em colunas distintas teve o propósito de verificar as mudanças nas propriedades da gasolina pela adição do álcool. A gasolina pura funcionou como parâmetro, e todas as modificações ocorridas no "outro" meio foram atribuídas ao álcool.

Verificou-se que com o mesmo volume injetado, as duas gasolinas comportaram-se de maneiras diferentes. Os efeitos percebidos com a adição de etanol à gasolina resumem-se:

- diminuição da espessura da fase livre devido a ação co-solvente do etanol na tensão interfacial água-gasolina;

- a E-24 move-se mais rápido que a gasolina pura;

- a relação de espessura da fase livre no poço de monitoramento e sua espessura no aqüifero foi de 4 , para a E-24, e 2.6, para gasolina pura. Isto indica que o programa de remediação aplicado para a E-24 baseado nos dados para gasolina pura podem super estimar o volume de produto a ser recuperado. 


\section{II - ABSTRACT}

The use of ethanol as a gasoline oxygenate has been suggested to substitute MTBE. Several countries such as Canada and Brazil use ethanol as gasoline enhancer. Brazil has been using $22 \%$ by volume for over 20 years and increased to $24 \%$ in the last year. Free-phase gasoline remedial schemes are based on the thickness of the gasoline layer measured on monitoring wells. The relationship of the thickness within the well and in the aquifer depends on the elevation of the water table. Since ethanol acts as a cosolvent, reducing the interfacial tension (IFT) between pure gasoline and water, the elevation of the capillary fringe is affected.

This work presents the effects of E24 compared to pure gasoline on the elevation of the capillary fringe and the correspondent thickness of free phase within the monitoring well and in the aquifer. Two plexiglass columns filled with glass beads were used to perform visualization experiments and to produce an appropriate relationship that can be applied to the field situations.

The results indicated that:

1) the elevation of the capillary fringe was lower for E24 compared to pure gasoline, as expected from the ethanol cosolvent effects on the IFT

2) using the same injection rate, E24 established a free phase layer faster than that of the pure gasoline. This indicates that during an E24 spill the product would move faster to greater distances compared to pure gasoline.

3) the migration of E24 to the well was faster than that of the pure gasoline, indicating that a subsurface spill could be detected earlier by monitoring wells installed within the gas station limits.

4) the relationship of the thickness of the free phase product within the well to thickness in the aquifer for E24 was 4 and for gasoline was 2.6. This indicates that a remedial scheme for E24 based on pure gasoline relationship would overstimate the volume of product to be extracted from the aquifer by $20 \%$. 


\section{III - INTRODUÇÃO}

O Congresso dos EUA em 1990 aprovou o Clean Air Act Amendments, movimento ambiental onde a gasolina foi um dos alvos de controle. A lei obrigou companhias de distribuição a adicionar oxigenados à composição da gasolina como meio de diminuir os componentes tóxicos emitidos para o ar. $O$ aditivo escolhido na época foi o MTBE (methil tert-buthyl ether). Tempo depois descobriram que enquanto reduz a poluição do ar, esta substância causa também poluição das águas e solo em dose crítica. Além de ser carcinogênica.

A solução encontrada no governo Clinton-Gore foi a substituição do MTBE por etanol. Com esta medida prevêem a proteção das águas, o ar limpo e promovem a utilização de um combustível renovável. Esta última estratégia agradou fazendeiros, através da criação de empregos rurais e promoção de energia alternativa, eliminando a dependência do petróleo importado.

O etanol foi apresentado ao mundo durante o embargo de petróleo árabe em 1970. Desde esta época o preço por galão de etanol oscilou até alcançar um valor competitivo ao da gasolina atualmente.

$O$ interesse econômico na utilização do etanol favoreceu pesquisas para caracterização dos efeitos deste álcool no meio ambiente. É importante conhecer o destino no solo e mecanismos de transportes para cada fase de desagregação do combustível no intuito de caracterizar o local e as dimensões da plumas. E assim aplicar-se o tratamento mais eficaz à remediação.

Os poços de monitoramento (PMs) são a base de todo estudo que envolve as técnicas de remediação de uma área. Informações como volume aproximado de combustível vazado, litologia local e anisotropia do terreno, profundidade de alcance do combustivel, potenciometria local são informações decorrentes da locação de poços de monitoramento. As análises de água subterrânea, subsídio da delimitação da pluma, são coletadas a partir destes, também ponto de arranque às medidas mitigadoras e contentoras da migração de contaminantes.

Uma das informações derivadas dos PMs diz respeito ao volume de combustivel vazado. Este trabalho pretende mostrar visualmente a diferença entre espessura de gasolina nos poços e a espessura no meio adjacente e interpretará a migração do contaminante da franja capilar. A super ou sub estimativa de volume implica em custos elevados na aplicação de técnicas de remediação. 


\section{IV - OBJETIVOS}

- Descrever alguns processos pelos quais passa a gasolina na franja capilar e suas interações até formar a fase livre

- Distinção do comportamento da gasolina pura e gasolina com etanol em meio poroso

- Mostrar visualmente a diferença de espessura entre a lâmina de combustível formada no interior dos poços de monitoramento e seu prolongamento no meio contíguo. 
Capitulo 1

\section{ELEMENTOS EM ESTUDO}

Os compostos orgânicos possuem algumas designações empregadas em referência a uma determinada propriedade físico-química. Deste modo tem-se NAPL (non aqueous phase liquids), líquidos em fase não aquosa, com referência à densidade dos compostos imisciveis. Possui a subclassificação de LNAPL (light non aqueous phase liquids), liquidos em fase não aquosa leve, e DNAPL (dense non aqueous phase liquids), liquidos em fase não aquosa densa, para produtos mais leves e mais densos que a água, respectivamente. As fases livres dos combustiveis, geradas com o vazamento, ocupam posições distintas para cada NAPL, 0 LNAPL permanece sobre o nivel d'água e o DNAPL afunda para a base do aquífero.

Outra designação para compostos orgânicos foi sugerida por Pinal et al (1990), CMOS (completely miscible organics solubility), solvente orgânico completamente miscivel, e PMOS (partially miscible organics solubility), solvente orgânico parcialmente miscivel, são os termos empregados para ênfase a miscibilidade dos orgânicos. Schiegg and Schwille (1989) recomendaram os termos HIL (heavy immiscible liquid), liquidos imisciveis pesados, e LIL (light immiscible liquid), líquidos imisciveis leves em substituição às outras siglas citadas.

A gasolina utilizada neste trabalho pertence ao grupo dos LNAPL e PMOS, líquido imiscivel menos denso que a água, ou orgânico parcialmente miscível em água. O segundo combustivel em estudo, o E-24, tem na composição a gasolina com as propriedades descritas e o etanol classificado como CMOS.

\section{1 - COMPOSIÇÃO DA GASOLINA}

A gasolina pontice a clico compostos orgânicos que apenas possuem hidrogênio e carbono na estuhura meculk, os hidrocarbonetos. Sua composição varia com origem/tipo de petróleo que a gerou, o grau de refino a que foi submetido o petróleo bruto e a presença de aditivos acrescidos ao produto final. Assim, no produto final há uma distribuição de mais de 200 compostos em uma rede de ligações químicas diversas, fazem parte deste conjunto os alcanos (cadeia ramificada e simples), alcenos, hidrocarbonetos monoaromáticos e os diaromáticos (naftaleno).

Cada processo do refino de petróleo gera gasolina possui os mesmos compostos, mas com alguma alteração de concentrações. Essas variantes de composição diferenciam as 
gasolinas quanto as propriedades físico-químicas. Por exemplo a volatilidade é atribuída a porcentagem composicional de butanos e pentanos em razão proporcional entre estes orgânicos (Anderson,1987 in Oliveira,1992). A volatilidade e solubilidade em água dos produtos de petróleo geralmente diminuem com o aumento do número de átomos de carbono na molécula.

A diferença composicional tem pouca variação. $O$ benzeno, por exemplo, tem concentração nas gasolinas de 2 a $8 \%$ nos padrões internacionais e $1 \%$ pela legislação brasileira. A mesma variação ocorre com os demais componentes do BTEX (benzeno, tolueno, etil-benzeno e os três isômeros do xileno), compostos da gasolina que têm a maior taxa de solubilidade, mobilidade e tempo de permanência em subsuperfície. Neste trabalho, no entanto, a gasolina será tratada como uma substância simples, sem referência aos comportamentos distintos de seus compostos.

\subsection{1 - Propriedades físico-químicas}

Oliveira (1995) mostrou em seu trabalho que as três propriedades da água e gasolina necessárias e suficientes para o entendimento da migração destes fluidos no meio poroso, quando o fluxo é unifásico, são a solubilidade, viscosidade e densidade.

\section{Solubilidade (mg/L e ppm)}

Valor referente à concentração de soluto que dissolve-se em água, a solubilidade de químicos orgânicos varia de concentrações máximas de cada elemento puro a índices mais baixos função da fração molar destes em misturas. Valores mais altos revelam que o determinado composto tem maior tendência a migrar para água quando submetido a ambientes aquosos.

$\mathrm{Na}$ composição da gasolina, os compostos de maior solubilidade são o BTEX, a Tabela 1.1 mostra a relação dos valores. A solubilidade em água dos produtos de petróleo geralmente diminuem com o aumento do número de átomo de carbono na molécula (Mackay e Cherry, 1989). Como mostrado na tabela, a solubilidade pode mudar com a forma e tipo de átomos que compõe a estrutura molecular do hidrocarboneto. Por exemplo, o benzeno é 141 vezes mais solúvel em água que o n-hexano. Esta é parte da razão pela qual muitas pesquisas se concentram nos aromáticos. 
Tabela 1.1 - Propriedades de hidrocarbonetos presentes na gasolina.

\begin{tabular}{|c|c|c|c|}
\hline Composto & Fórmula & Peso Molecular $(\mathrm{g} / \mathrm{mol})$ & Solubilidade $(\mathrm{mg} / \mathrm{L})$ \\
\hline Benzeno & $\mathrm{C}_{6} \mathrm{H}_{6}$ & 78,1 & 1790 \\
\hline Tolueno & $\mathrm{C}_{7} \mathrm{H}_{9}$ & 93 & 515 \\
\hline Etilbenzeno & $\mathrm{C}_{8} \mathrm{H}_{11}$ & 107 & 230 \\
\hline p-Xileno & $\mathrm{C}_{8} \mathrm{H}_{12}$ & 106,2 & 180 \\
\hline n-hexano & $\mathrm{C}_{6} \mathrm{H}_{5}$ & 86,2 & 12,7 \\
\hline
\end{tabular}

O valor da solubilidade de um composto puro é maior que a solubilidade deste mesmo composto quando este faz parte de uma mistura. Baseado na lei de Raoult,

$$
S i=S p i \quad x \quad M f i
$$

onde,

$S_{i}$ é a solubilidade efetiva do componente na mistura $\left[{\left.\mathrm{M} . \mathrm{L}^{-1}\right]}^{-1}\right.$

$S_{p i}$ solubilidade efetiva do componente i na forma pura $\left[M . L^{-1}\right]$

$M_{f i}$ é a fração molar do componente na mistura (gasolina).

Ainda que a solubilidade varie com a fração molar do hidrocarboneto os compostos . Normalmente presente na composição da gasolina brasileira a índices de $1 \%$, a máxima solubilidade efetiva alcançada é aproximadamente $18 \mathrm{mg} / \mathrm{L}$. Apesar da redução, este valor está acima do padrão brasileiro (CETESB, 1990) de tolerância de benzeno em água potável, $10 \mu \mathrm{g} / \mathrm{L}$.

Na relação da solubilidade e outras propriedades, como por exemplo a mobilidade, tem-se que quanto mais solúvel o composto maior mobilidade possui, traduzindo no poder de extensão da pluma de contaminação.

A solubilidade do elemento puro diminui em decorrência da fração molar deste em uma mistura e aumenta com adição de oxigenados na mistura. Este aumento deve-se a quebra de ligações entre os compostos na solução original.

O etanol adicionado à gasolina tem o poder de aumentar a solubilidade do BTEX, promovendo maior mobilidade destes compostos na água. 


\section{Viscosidade $(\mu)$}

Habilidade do fluido de resistir à deformação. Em termos de mecânica de fluidos esta deformação é decorrente do fluxo. A medida da viscosidade é desta forma a relutância do fluido ao stress quando submetido a movimento (Bear, 1972). O aumento da viscosidade implica em menor mobilidade dos combustíveis líquidos.

Para os hidrocarbonetos a viscosidade varia com as condições ambientais, é altamente dependente da temperatura. Clima quente diminui a viscosidade, resultando em escoamento mais rápido. Clima frio resultará em maior viscosidade, escoamento retardado e consequentemente maior perda de massa devido ao maior tempo de contato do combustível com o solo. Em líquidos, geralmente a viscosidade aumenta com a pressão a temperaturas constantes, mas a água é uma exceção, a viscosidade diminui com a pressão a temperatura constante.

Para este trabalho, o efeito da pressão e temperatura na viscosidade será desprezado. Para haver uma baixa mudança na viscosidade o sistema deve ser submetido a um grande aumento de pressão. Isto equivale Um grande aumento na pressão produz uma baixa mudança na viscosidade equivalente para produzir uma baixa redução na temperatura (Popovich and Hering, in Bear, 1972). Como as variações de pressão nas colunas são internas e de baixa intensidade.

O efeito do etanol sobre a viscosidade será o único fator relevante neste trabalho. A viscosidade é reduzida com a adição do álcool a gasolina. A gasolina menos viscosa tem maior mobilidade. Fluidos viscosos tendem a impedir que a ação da gravidade faça o produto infiltrar a maiores profundidades. Esta barreira inibe a adsorção pelo solventes enquanto o combustível forma um coágulo.

A viscosidade como parâmetro único não determina mobilidade de fluidos. Observa-se o exemplo do $\mathrm{CCl}_{4}$, cuja viscosidade, 0,97 centipoise, é aproximadamente igual a da água, 1,00 centipoise. O fluxo de cada substância seria o mesmo se não fosse a diferença entre a tensão superficial dos dois fluidos. $\mathrm{A} 20^{\circ} \mathrm{C}$ a tensão superficial da água é $73,05 \mathrm{dina} / \mathrm{cm}$ e do tetracloreto de carbono é $26,95 \mathrm{dina} / \mathrm{cm}$. Assim a água estará mais presa no meio poroso não saturado devido a maior tensão superficial. $\mathrm{O} \mathrm{CCl}_{4}$ tem maior mobilidade. 


\section{Densidade $(\rho)$}

A densidade é a propriedade mais importante, junto a viscosidade, no controle do fluxo em subsuperfície. É definida como massa do material por unidade de volume.

Gravidade específica ou densidade relativa de um composto é a razão da massa do composto pela massa de água, ambos com o mesmo volume.

Os combustíveis utilizados no experimento possuem as seguintes especificações:

Tabela 1.2 - Densidades da gasolina pura e E-24

\begin{tabular}{|c|c|c|}
\hline Gasolina pura & Densidade relativa a $20 / 4^{\circ} \mathrm{C}$ & $0,7365 \mathrm{~g} / \mathrm{cm}^{3}$ \\
\hline Álcool anidro & Massa específica a $20^{\circ} \mathrm{C}$ & $0,7897 \mathrm{~g} / \mathrm{cm}^{3}$ \\
\hline E-24 & Densidade (Oliveira, 1997) & $0,7241 \mathrm{~g} / \mathrm{mL}$ \\
\hline
\end{tabular}

Os valores das densidades foram fornecidos pela empresa fornecedora dos combustíveis, Companhia Brasileira de Petróleo Ipiranga (CBPI), com exceção da E-24, cujo cálculo baseou-se no experimento de Oliveira (1997).

A Figura 1.1 representa a correlação entre as densidades do etanol, água e gasolina apresentado por Oliveira (1997). As densidades da água e gasolina são importantes para determinação da estabilidade no processo de drenagem. Ao variar as composições das fases de gasolina ou aquosa, com a presença do etanol, as densidades também modificam-se afetando o volume final da mistura. O volume final da mistura sofre redução. A região de duas fases é a área onde as mudanças de volume são maiores.

A mistura etanol-água possui volume e densidade diferentes da soma dos valores de cada substância em separado. $O$ volume da mistura sofre redução ocasionado pelo aumento da densidade. Este mesmo cálculo para a mistura etanol-gasolina revela uma diferença inferior do apresentado para mistura etanol-água. A mudança de volume máxima $(-3,4 \%)$ ocorre no eixo água-etanol do diagrama, onde há somente água pura e etanol puro.

A variação grada do valor mais alto (tom mais escuro), correspondendo à água pura, ao valor mais baixo, correspondendo à gasolina (tom mais claro). A Figura 1.1 indica que (i) ao longo da curva de solubilidade a fase gasolina é menos densa que a fase aquosa; (ii) a mistura etanol-água, com o conteúdo mínimo para deslocamento miscivel $(88 \%$ do peso do etanol), terá densidade mais alta que a fase gasolina e menor densidade que a água. 


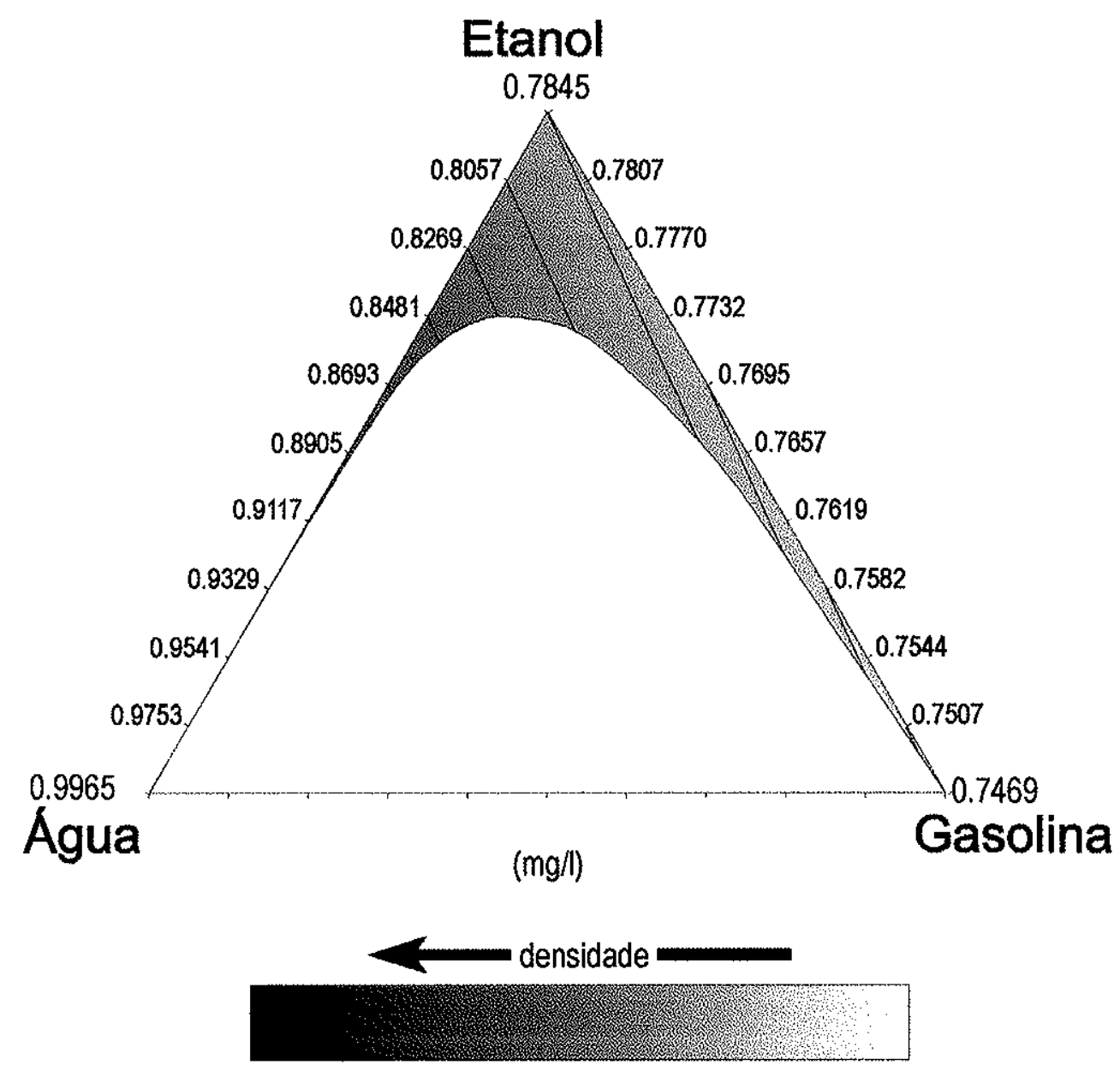

Figura 1.1 - Distribuição de densidade para o sistema pseudo-ternário gasolina-água-etanol (Oliveira, 1997)

As mudanças no volume devido as interações moleculares entre água e etanol criam uma região de baixa pressão, com a consequente formação de fase vapor. A degasificação da água ocorre devido a mistura com o etanol. As mudanças na estrutura interna da fase aquosa resulta na formação de fase gasosa.

\section{2 - PARTIÇÃO}

A característica polifásica da gasolina está associada às quatro fases em que o combustivel se desagrega após vazamento no solo. Partição é o termo empregado para a divisão da gasolina nas quatro fases. A Figura 1.2 mostra ilustra os locais no subsolo e formas adquiridas pela gasolina após vazamento, fases dissolvida, vapor, livre e residual. 


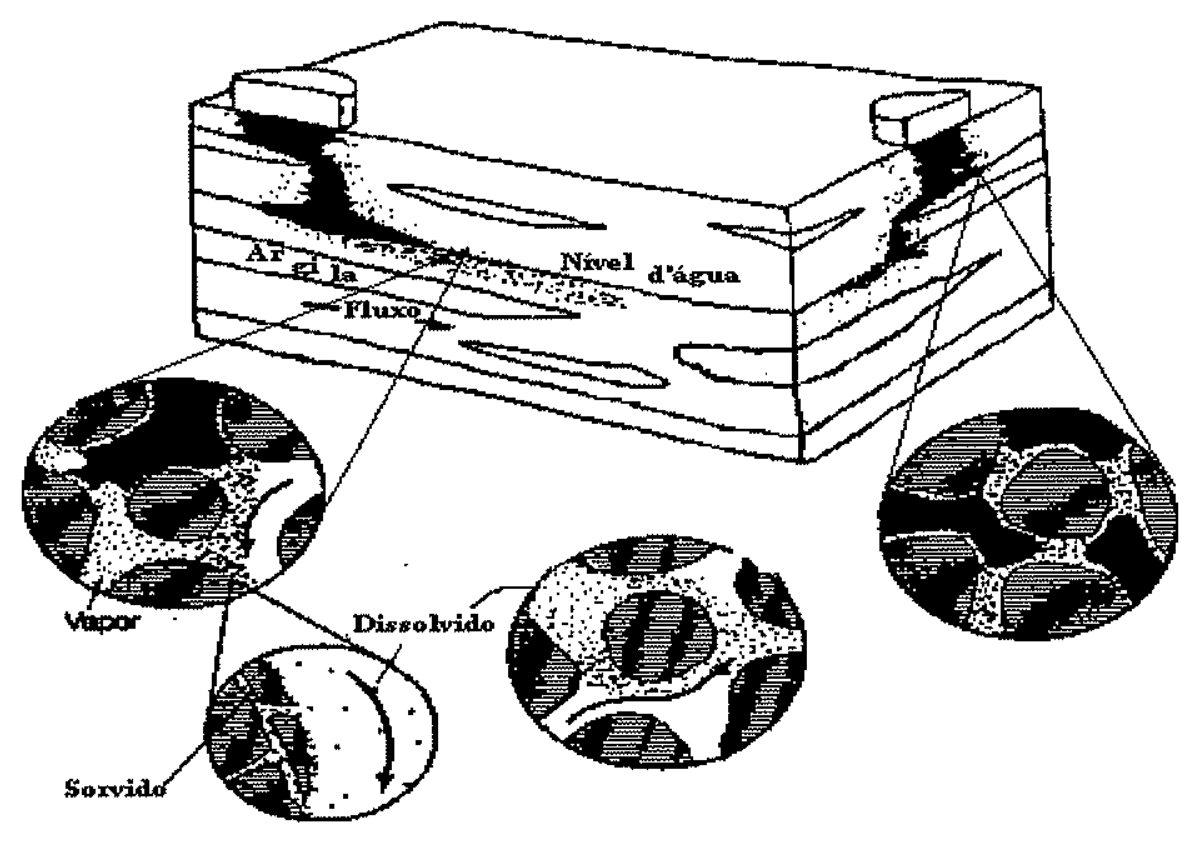

Figura 1.2 - Fases da gasolina no subsolo (modificado de Mackay e Cherry ,1989)

A complexa composição química da gasolina faz com que os compostos partam-se para cada fase de acordo com suas propriedades físico-químicas. Os compostos alifáticos são voláteis partindo-se para fase vapor, os elementos aromáticos voláteis e solúveis e partem-se para fase dissolvida e gasosa.

Oliveira (1992) reuniu estas fases em grau de volume e teor contaminante:

\begin{tabular}{|c|c|c|c|c|}
\hline Fase & $\begin{array}{c}\text { Volume contaminado } \\
\text { de solo }\left(\mathrm{m}^{3}\right)\end{array}$ & $\begin{array}{c}\% \text { total } \\
\text { Livre }\end{array}$ & $\begin{array}{c}\text { Volume de contaminante } \\
\left(\mathrm{m}^{3}\right)\end{array}$ & $\%$ total \\
\hline Residual & 250.100 & 1 & 18.500 & 62 \\
\hline Dissolvida & 960.000 & 79 & 10.000 & 33 \\
\hline
\end{tabular}

Groundwater Technology Inc., 1983 in Oliveira, 1992

Apesar da fase livre conter a maior concentração de contaminante, também concentra a menor taxa de contaminação de solo em relação às outras fases. A maior complexidade está na zona saturada onde o fluxo d'água é o responsável pelo aumento da área de contaminação da fase dissolvida, embora com menor concentração de elementos tóxicos que as outras duas fases. 
A gasolina, ao vazar para o meio, disassocia-se em fases distintas a depender do meio e do contato com outros fluidos constituintes deste ambiente. Assim tem-se:

\section{Gasolina pura em estado líquido}

Representa a fase da gasolina imiscivel em água e que por ação das forças capilares e da gravidade têm diferentes disposições:

1) Bolsões - lentes de gasolina dispostas na zona não saturada, presas por diferença de condutividade hidráulica no meio, mas que podem fluir para os poços se tiver uma massa suficiente para tanto.

2) Saturação Residual - glóbulos (bolhas) de gasolina presas aos poros sob ação de forças capilares. Característica: (i)mobilidade, a mobilidade (transiente) pode ser induzida por precipitação ou variação do nível d'água.

3) Fase Livre - lente de gasolina sobre a franja capilar difere da fase residual quanto ao volume despreendido/conectado e mobilidade.

\section{Fase Dissolvìda}

Apesar de classificada como fluido imiscivel a gasolina possui em sua estrutura compostos solúveis em água, que formam a fase dissolvida de uma contaminação. O transporte e a extensão da pluma formada pelos elementos solúveis são função da solubilidade dos compostos e da velocidade da água subterrânea. Como neste experimento não há fluxo de água que configure a advecção, e por conseguinte a dispersão, toda a fase dissolvida será função da solubilidade dos compostos.

\section{Fase vapor}

A fase vapor pode ser o resultado da volatilização da gasolina na fase livre, residual ou dissolvida. Compõe o estado gasoso do solo, mas podem se condensar e ser adsorvidos pelos sedimentos ou dissolver na água subterrânea.

A dissolução do contaminante começa no poro preenchido por água da zona não saturada e continua quando o poluente alcança o aquífero.

Sob condições naturais, o transporte de vapor ocorre principalmente por difusão, que é primariamente o resultado do gradiente de concentração. Barreiras naturais como lentes de argila impermeáveis, camadas subterrâneas de solo resfriado, fratura selante, ou ainda materiais artificiais como concreto e polietileno podem desviar ou trapear a fase vapor. Seu 
fluxo não está completamente relacionada com a posição espacial da fonte, pode estar a margem da fase livre.

\section{3 - ETANOL}

O etanol pode ser encontrado em postos de serviços das seguintes maneiras,

- álcool combustível

- o álcool aditivo, álcool anidro

Estes possuem a mesma composição química diferem-se quanto ao teor alcoólico ou hidratação. O álcool utilizado como combustivel puro possui o teor alcoólico de 92 ${ }^{\circ}$ INPM, enquanto o álcool na mistura com gasolina o teor é de >99,5 INPM (CBPI, 2000).

O funcionamento de um carro tem como sistema de ignição os motores de explosão, a gasolina e o ar são comprimidos e em seguida ocorre a detonação promovida pela faísca produzida pela vela. A qualidade de uma gasolina é medida pelo índice de octanos que varia de zero a 100. Gasolina de índice de octanos zero é aquela que explode prematuramente por compressão. Gasolina de índice de octanos 100 resiste à compressão. Uma gasolina de péssima qualidade explode por simples compressão, enquanto a gasolina de boa qualidade, resiste a compressão sem sofrer detonação prematura.

Normalmente muitos oxigenados como álcools e éters são adicionados a gasolina para aumentar o índice de octanagem e reduzir a poluição do ar devido à combustão. $O$ etanol impulsiona a pressão na gasolina, implementa a octanagem e permite a compressão na ignição do cilindro.

\subsection{1 - Co-solvência}

Oxigenados são substâncias que contém oxigênio com a função de permitir a queima mais eficiente de gasolina. Minimiza a emissão de poluentes como monóxido de carbono e benzeno para a atmosfera.

Os efeitos produzidos pelo etanol na gasolina como combustivel já foram vistos. Esses benefícios não são projetados quando a situação envolve a relação do combustivel aditivado e o meio ambiente.

Em primeira análise, a adição de etanol à composição de gasolina diminui a fração molar de compostos da gasolina, principalmente o BTEX, aromáticos mais tóxicos e de maior 
persistência no aquífero. A partir disso, tem-se que a diminuição da fração molar do BTEX na gasolina, diminuiria sua participação também no meio, mas o efeito cosolvente dos aditivos interfere nas propriedades do BTEX levando-o a maior partição destes para água.

Conceituando o efeito, tem-se que aos compostos orgânicos que possuem o elemento oxigênio em sua estrutura são chamados oxigenados. Classe que inclui eteres e álcools. $O$ caráter co-solvente destes compostos diz respeito ao poder que possuem de dissolverem-se em água (polar) e em gasolina (apolar), provocando diminuição da tensão interfacial entre a água e a gasolina no meio poroso; modificação dos volumes, densidades e composição molar da gasolina e água envolvida na interação.

A solubilidade é uma das propriedades físico-quimicas afetadas com a cosolvência. Para combustíveis com alto conteúdo de oxigenados, o teor de BTEX será reduzido. Da Equação (1.1) tem-se que a diminuição do conteúdo de BTEX na gasolina tenderá a diminuir sua concentração nas águas subterrâneas. Entretanto, o efeito cosolvente do aditivo altera a solubilidade da fase pura do composto de petróleo tornando-o mais solúvel e ocupando maior extensão das águas subterrâneas.

A interação de etanol irá modificar a molhabilidade, que é frequentemente definida com base no ângulo de contato entre os fluidos em relação ao sólido. Oliveira (1997), explica que o etanol presente na mistura E-20,80\% gasolina e $20 \%$ etanol, apresenta tendência a particionar-se para a água do meio poroso, seu efeito cosolvente reduz a tensão interfacial entre a gasolina e a água, facilitando a entrada do $\mathrm{E}-20 \mathrm{em}$ poros cujos diâmetros seriam muito pequenos para a gasolina pura penetrar.

No experimento de Barker (1991), os efeitos do metanol incluem aumento da solubilidade do BTEX, produzindo uma alta concentração inicial de benzeno quando a concentração de metanol também era alta. Por sua completa miscibilidade em água o metanol participa em maiores proporções que o BTEX nas águas subterrâneas afetadas por vazamento de oxigenados/gasolina. Compostos altamente solúveis têm baixo potencial de adsorção, por conseguinte o metanol possui maior mobilidade em água subterrânea que a gasolina.

Altas concentrações do álcool reduzem a retardação do BTEX. O efeito co-solvente aumenta a solubilidade do BTEX e induz consequentemente a maior mobilidade destes compostos na água subterrânea.

Outro efeito destacado por Barker (1991) diz respeito a biodegradação. O álcool será biodegradado antes do BTEX e consumirá o oxigênio necessário a degradação biológica do 
BTEX. Ainda o oxigenado poderá ser tóxico e inibidor das bactérias que promovem a degradação dos compostos da gasolina. É associado também ao metanol, em alta concentração, produzir menor retardação do BTEX.

\section{4 - Diagrama Pseudoternário}

Os efeitos provocados pelo etanol em ambiente microscópico e macroscópico contendo inicialmente água e/ou gasolina foram estudados por Oliveira (1997). Agora será transcrito resumidamente o comportamento do etanol como substância única injetado no protótipo de meio poroso descrito por Oliveira (1997). Após estas considerações será feita analogia ao caso deste experimento, onde o etanol já faz parte da mistura (E-24) e passa a integrar um meio composto por ar e água.

Os parâmetros de medidas foram a densidade, volume e concentração de cada fase envolvida, a fase aquosa e a fase gasolina e de cada substância envolvida, etanol, gasolina e água.

Inicialmente, os três elementos foram conduzidos como substâncias simples, apesar da gasolina ser uma mistura, e agrupados no diagrama (pseudo)ternário, Figura 1.3. A composição dos pontos ao longo da curva binodal foram determinadas em porcentagem em volume e transformadas em percentual em peso utilizando as densidades dos componentes de cada vértice.

As retas que compõem o diagrama são formadas por pontos que representam estágios de composição das misturas. As linhas de equilibrio, na região de duas fases, unem pontos que representam concentrações da fase água e da fase gasolina. O ponto de coexistência representa o ponto onde a concentração das duas fases se igualam e o sistema de duas fases passa a ter fase única.

Os pontos a serem observados no diagrama, Figura 1.3, dizem respeito:

- a grande área da região de duas fases;

- a proximidade entre a fração rica em água e a curva binodal do lado água-etanol do diagrama, indicando baixa solubilidade da gasolina em baixo conteúdo de etanol (menor que $50 \%$ ). Acima de $50 \%$ do etanol a solubilidade da gasolina aumenta gradualmente como sugere o desvio progressivo da curva do eixo etanol-água do diagrama. Oliveira (1997) 
ressalta que baixas solubilidades de gasolina em água no contexto são ordens de magnitude mais altas que a solubilidade original da gasolina;

- pouca gasolina é incorporada à fase aquosa que contém etanol dissolvido. Após acréscimo de $88 \%$ de etanol a gasolina passa a ter maior concentração na mistura;

- ao longo das linhas de equilibrio, nos extremos os dois elementos têm composição própria e as duas fases têm composições mista. À medida que mais etanol é adicionado, as duas fases tendem composição única;

- a inclinação das linhas de equilíbrio, tendendo para o ponto único à direita, caracteriza o sistema onde o etanol particiona-se preferencialmente para fase aquosa;

- o topo da curva binodal coincide com a marca de $~ 70 \%$ do peso do etanol, ou seja, com este conteúdo de álcool qualquer composição passa a ser fase única. Os fluidos residuais (água e gasolina) misturam-se no fluxo.

Para o caso do experimento aqui desenvolvido o etanol na mistura (E-24) passa a integrar o meio poroso composto por ar e água. Lembrando que o etanol tem tendência a partir-se para água, o álcool contido na E-24 migrará para a água carreando os hidrocarbonetos da gasolina mais solúveis em água.

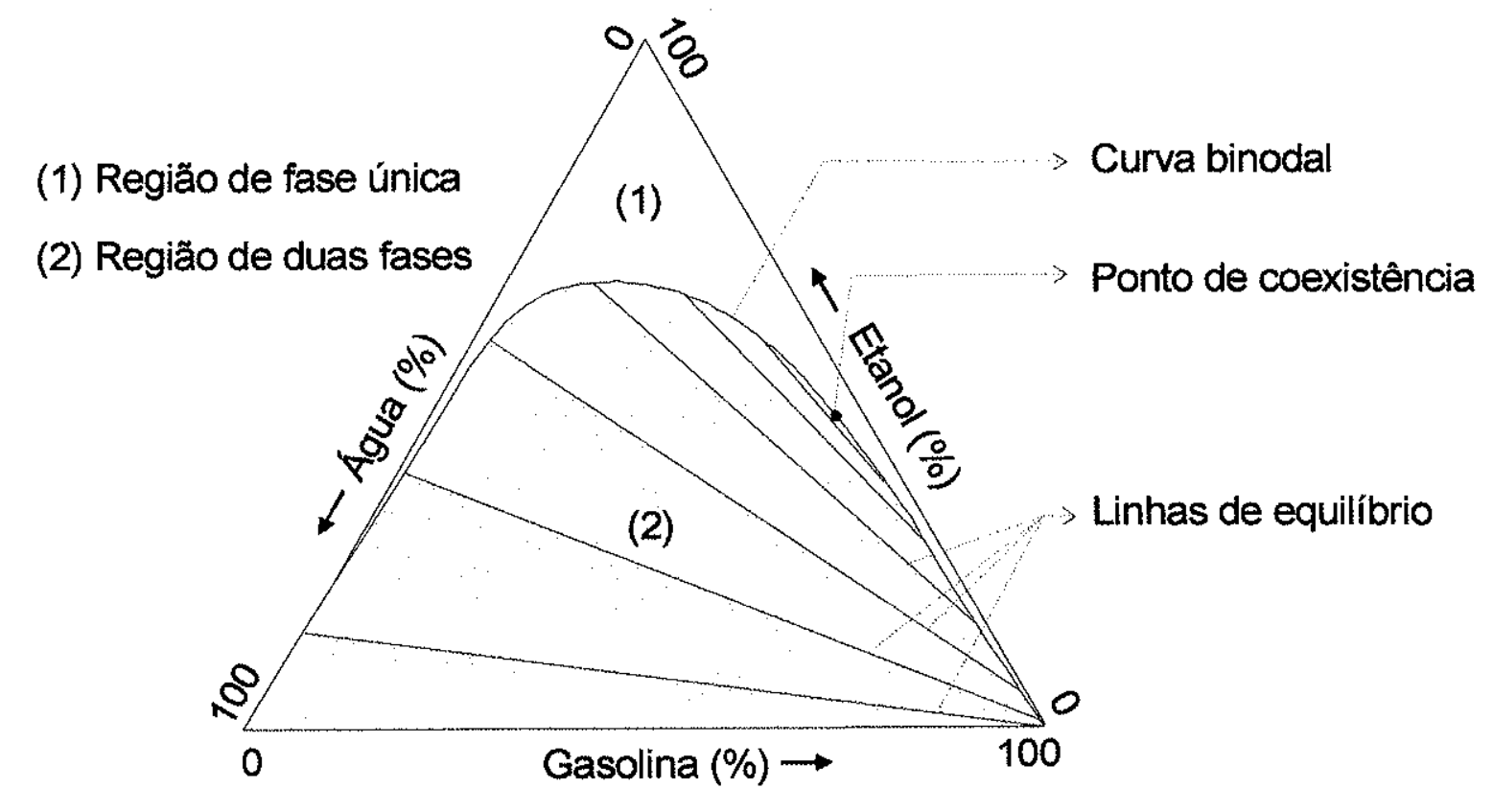

Figura 1.3 - Diagrama pseudo-ternário para o sistema gasolina-etanol-água (Oliveira, 1997) 


\section{Capítulo 2 \\ MATERIAL E MÉTODOS}

\section{1 - Montagem das Colunas}

O princípio do experimento baseou-se no desenvolvimento de condições laboratoriais que descrevessem, o mais próximo do real, a relação água subterrânea- gasolina, observada em campo. Desta maneira dois sistemas foram construídos caracterizando, cada um, um aquífero freático, montado segundo os mesmos procedimentos e diferindo conforme 0 combustivel disposto no meio. Um dos sistemas simulou um vazamento de gasolina pura e o outro de gasolina comum, E-24, com $24 \%$ de etanol e $76 \%$ de gasolina.

Segundo Lal et al (1970) a situação de campo pode ser razoavelmente aproximada em laboratório utilizando uma coluna de solo, com correção apropriada, envolvendo a densidade e distribuição granulométrica, que permita uma expansão vertical livre do solo argiloso. Isto pode ser parcialmente alcançado com a correta análise do diâmetro da coluna,

granulometria dos sedimentos e contato deste com a parede da coluna preenchida. A partir destas características para solos expandidos, observadas por Lal et al (1970), baseou-se as dimensões para o experimento de migração livre da gasolina.

Dois cilindros de diâmetros distintos foram ajustados para configurar um aquífero freático. A coluna de maior diâmetro, manufaturada em acrílico transparente com $100 \mathrm{~cm}$ de comprimento e $23 \mathrm{~cm}$ de diâmetro interno, foi objeto de acondicionamento do meio poroso para posterior disposição de gasolina. Outro cilindro, desta vez de PVC cristal rígido com dimensões de $100 \times 3 \mathrm{~cm}$, foi secionado ao longo do comprimento, ranhurado ao longo de sua superfície e pressionado à parede interna do cilindro maior com função de poço de monitoramento (PM), Figura 2.1.

A fim de evitar o efeito de paredes (migração preferencial do fluido pelas paredes internas da coluna em vez de percórrerem o meio) Schiegg e McBride (1987) propuseram uma largura mínima de $15 \mathrm{~cm}$ para a coluna comportar sedimentos de granulometria inferior a $0,35 \mathrm{~mm}$. Esta relação propicia o aumento de porosidade nas proximidades das paredes da coluna e impele a água a propagar-se no meio poroso. Com este mesmo propósito, além de proporcionar uma precisão dos processos de infiltração e avanço da frente molhante, Lal et al (1970) fizeram testes com diferentes diâmetros de colunas e granulometria de sedimentos 
e estimou em $10 \mathrm{~cm}$ o diâmetro mínimo e fração granulométrica entre $0,5-1 \mathrm{~mm}$ como as medidas mais favoráveis a verificação das relações de campo para laboratório.

As dimensões escolhidas seguem também o padrão utilizado por Adams e Hampton (1992) e Abdul et al (1989) onde foi obedecida a proporção de volume entre os cilindros de 5:1. Estas medidas foram adotadas para propiciar migração vertical de gasolina e inibir o transporte horizontal a longa distância.

Adotou-se, a partir das considerações citadas, $23 \mathrm{~cm}$ para o diâmetro interno da coluna maior para comportar grãos de $850 \mu \mathrm{m}$ e $3 \mathrm{~cm}$ de diâmetro interno para o cilindro menor. Esta relação minimiza os efeitos da parede, em que o fluxo da água nas proximidades das paredes internas não prevalece sobre o meio poroso, e condiciona a migração horizontal da gasolina em direção ao poço de monitoramento.

Quanto ao meio poroso, este não foi representado por material geológico natural, em seu lugar, micro esferas de vidro de $850 \mu \mathrm{m}$ de diâmetro efetivo preencheram o espaço entre a coluna de diâmetro maior e a seção do cilindro interno. Sua composição compreende $97,5 \%$ de quartzo, bem selecionado, densidade de $2,75 \mathrm{~g} \cdot \mathrm{m} / \mathrm{cm}^{3}$ e baixa umidade. Na classificação sedimentar da M.I.T \& B.S., Dullien (1992), estas esferas estão inseridas na escala de areia média a grossa:

A escolha de material não natural teve o objetivo de desprezar a perda de massa proveniente da adsorção e do efeito de microorganismos pertencentes a estrutura do solo real. Além de proporcionar transparência e homogeneidade requeridas aos objetivos do experimento. Simmons et al (1992) afirmam que simulações utilizando esferas de vidro oferecem dados confiáveis para experimentos com infiltração de orgânicos e suas derivações.

No processo de preenchimento da coluna pelas esferas houve atenção para garantir a homogeneidade do meio. Para tanto houve seleção da fração dos "sedimentos" que garantissem o padrão dos $850 \mu \mathrm{m}$ e, durante a compactação, as esferas foram arranjadas de tal modo que se impedisse a formação de lentes ou camadas.

Visto que a meta deste trabalho é mostrar visualmente a diferença de espessuras entre a gasolina no poço e no meio poroso, o vidro e o acrílico foram os materiais escolhidos para proporcionar uma melhor percepção desta relação. Além de satisfazer o critério da transparência, trabalhar com as esferas propiciou um ajuste a homogeneidade e isotropia utilizados nas equações e pesquisas desenvolvidas. Adams e Hampton (1992) testaram 
materiais como teflon, acrílico, aço inoxidável e fibra de vidro em experimento semelhante a fim de verificar a alteração causada na utilização de materiais diferentes. Nenhum efeito adverso foi notado.

A injeção de água no sistema (coluna e esferas) foi realizada por uma válvula instalada na parte inferior da coluna e ajustada a esta por uma flange selada internamente para o diâmetro das micro esferas. A borracha de vedação da flange foi substituída por um anel O-Ring de viton, material escolhido para vedar a conexão, pois tem alta resistência à gasolina. As conexões têm $15 \mathrm{~cm}$ de comprimento e o flange $3 / 4$ de polegada.

O mecanismo para injeção de água no sistema consistiu em um tambor de 21L, elevado até o nível superior da borda da coluna, de onde uma mangueira fez conexão e a água iniciou a migração no meio poroso, Figura 2.2. Análogo a um sistema de manômetro, nesta montagem a água terminou seu trajeto após os níveis da coluna e do tambor se equipararem. A elevação do nível d'água foi visualizada através do poço de monitoramento e a frente molhante, no meio poroso, pela parede da coluna, Figura 2.3.

A gasolina foi injetada no sistema diretamente sobre a franja capilar. Após o cálculo para definição da posição da franja, um conduto foi posicionado nesta altura e por meio deste a gasolina penetrou no meio.

A parte superior da coluna foi coberta com uma placa horizontal lisa a fim de evitar escape de voláteis após a simulação do vazamento de gasolina.

Os experimentos foram conduzidos utilizando nas duas colunas gasolinas pigmentadas. Os dois tipos de soluções utilizados no experimento, gasolina pura e E-24, passaram por produto corante oleofílico com a finalidade de fornecer contraste visual entre os fluidos no sistema.

A escolha do corante oleofílico procedeu-se àquele que fornecesse melhor matiz de cor, evitando, no entanto, modificações às propriedades físico-químicas (densidade e viscosidade) da água e gasolinas. Após testes desenvolvidos em laboratório a Ditizona foi o pigmento escolhido.

O processo de pigmentação da gasolina envolveu mistura do combustivel e corante a proporção de $200 \mathrm{~mL}$ para $1 \mathrm{mg}$, agitador mecânico, filtragem da mistura para retenção dos resíduos, descanso por um período de uma hora para ratificar a eliminação de resíduos.

Apesar de utilizada a mesma substância corante para os dois tipos de gasolinas, os combustiveis apresentaram cores diferenciadas. Nas fotos nota-se o vermelho destacando a gasolina pura e o alaranjado mostrando a E-24. 


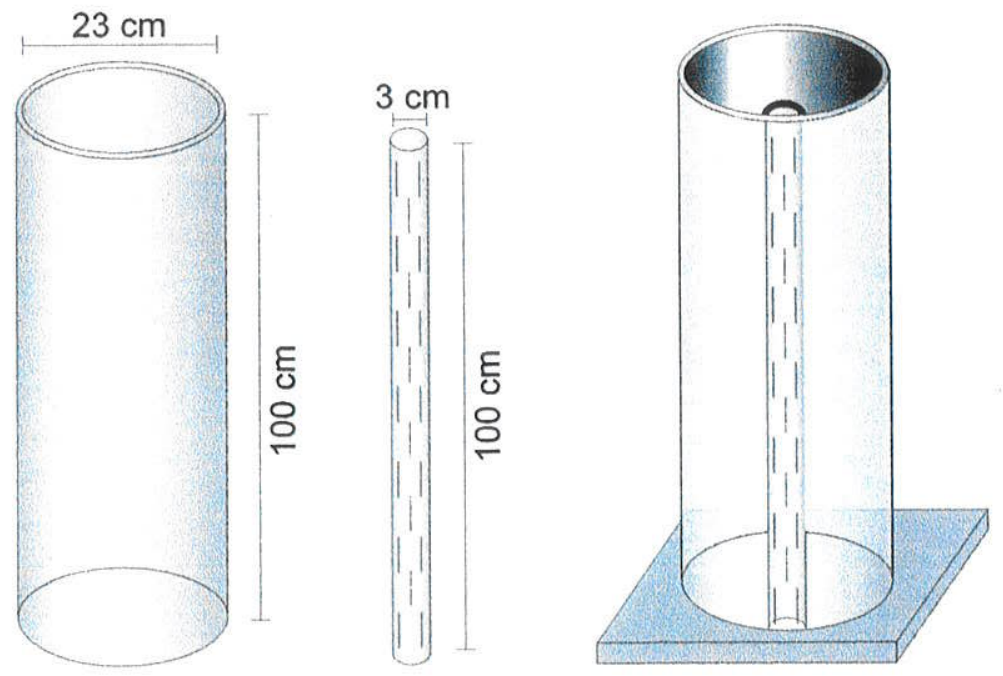

Figura 2.1 - Esquema de montagem de uma coluna

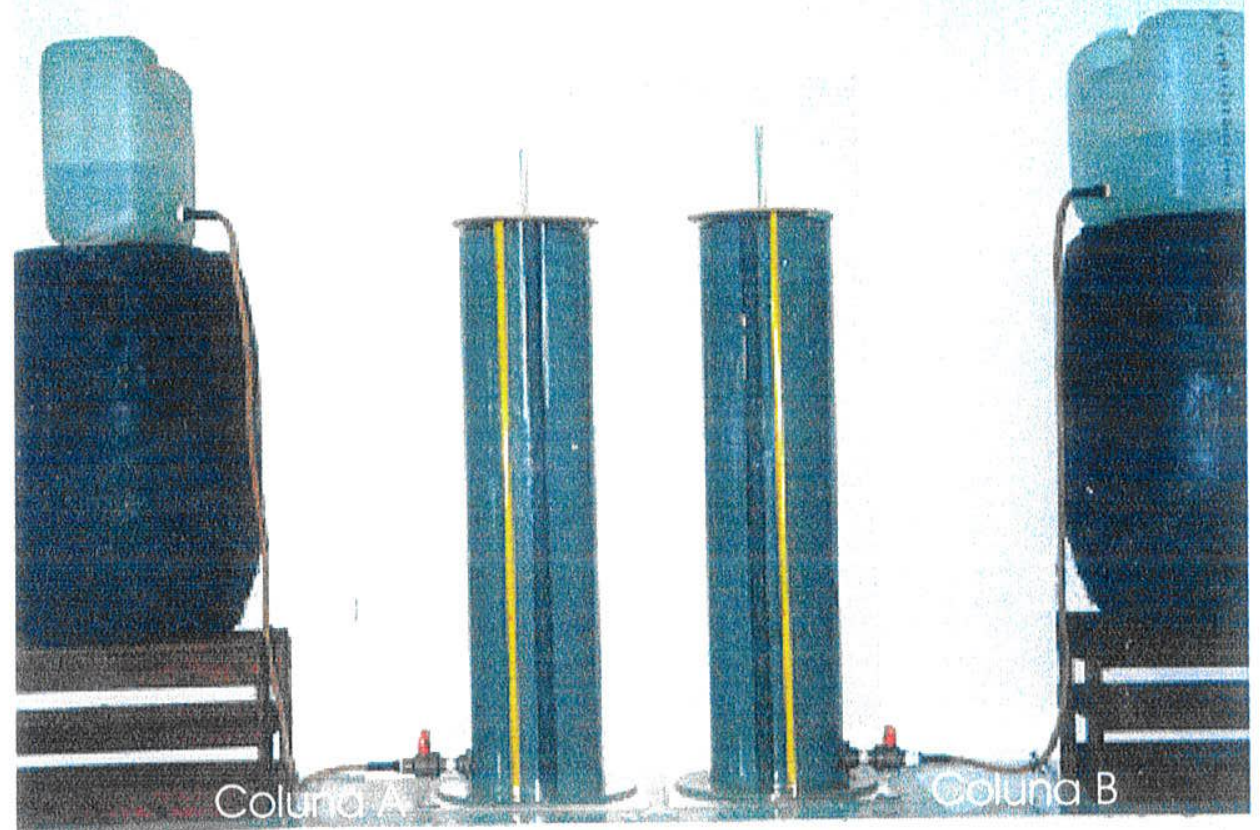

Figura 2.2 - Montagem completa dos sistemas, coluna A e Coluna B.

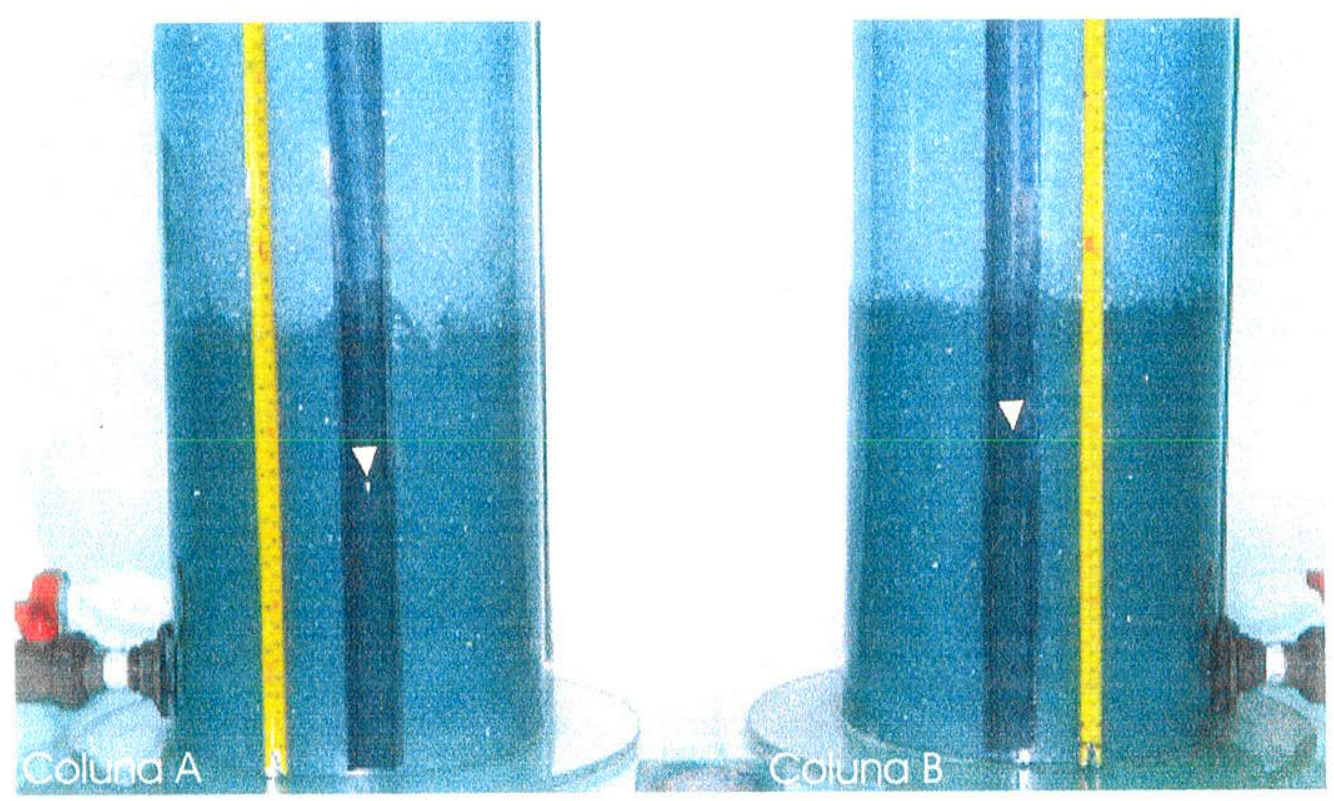

Figura 2.3 - Acompanhamento da frente molhante e nivel d'água. 
O passo conseqüente à construção das colunas, que constou com o ajuste dos sedimentos, instalação do poço de monitoramento e fonte de recarga de água, foi a definição dos limites naturais do aquifero freático.

O aqüifero foi desenvolvido com definição das zonas, saturada e não saturada. $A$ delimitação ocorreu com a distinção dos niveis das zonas pela água deionizada e deaerada, e determinação da franja capilar.

Pesquisadores como Philip (1969), Bond e Collins-George (1981) e Klute (1986), todos in Oliveira (1995), sugerem a utilização de água natural na condução dos experimentos, defendem que o uso de água pura pode camuflar os resultados das relações com os sedimentos coletados no campo. Como neste experimento descartou-se o uso de solo real, pelos motivos já esclarecidos, a utilização de água não natural visa a não reação química com os elementos do meio e garantia da presença apenas dos compostos da gasolina e água, no caso da água deionizada, e a não formação de bolhas de ar no meio poroso reduzindo a permeabilidade, além de assegurar presença de apenas um fluido, a água, no meio, no caso da água dearada.

\subsection{1 - Saturação por Água}

Após o preenchimento da coluna por micro esferas de vidro, iniciou-se a saturação feita por água deionizada e deaerada com fluxo vertical iniciado na parte inferior da coluna.

$\mathrm{Na}$ bibliografia, o conceito de infiltração diz respeito ao escoamento de água na superfície de um terreno para o interior do solo. O termo será aqui empregado referindo-se ao movimento da água para o interior do melo poroso, independente da fonte ou recarga estar posicionada na superfície ou na base do sistema representativo do aqüífero. $O$ termo será também estendido à gasolina.

O procedimento de infiltração da água pela base da coluna e a padronização da velocidade da migração foram medidas complementares às propriedades da água para garantir que o ar não ficasse retido entre os grãos e gargantas no meio poroso. Oliveira (1995) explica que o rápido avanço da água pelos poros menores fecha alguns condutos do trajeto. Neste fechamento o ar é trapeado nos poros maiores. 
Em referência às dimensões da coluna e preenchimento por água, Lal et al (1970) notaram uma interação insignificante entre o diâmetro da coluna e a fração do solo nos estágios iniciais de infiltração, mas para tempos maiores todos os três fatores (diâmetro, fração dos grãos e a interação entre eles) controlam significantemente o movimento da frente molhante. Para Lal et al (1970) o diâmetro da coluna é indiscutivelmente o fator mais importante no controle da frente moihante.

A gravidade foi o único fator atuante na indução de água para o sistema. Por ação desta força a água passou do tambor à coluna no processo de infiltração. A ascensão da água foi acompanhada através do poço de monitoramento e a frente molhante, no meio poroso, pela parede da coluna. O procedimento foi conduzido a uma velocidade de aproximadamente $0,2 \mathrm{~cm} / \mathrm{s}$ até atingir o topo da coluna, Figura 2.4 .

Durante a saturação, a frente molhante permaneceu razoavelmente uniforme na direção horizontal, indicando uma "sedimentação" relativamente homogênea, Figura 2.5.

Nos experimentos conduzidos por Oliveira (1995), as equações de Green and Ampt (1911) e Brutsaert (1977) foram apontadas como as mais representativas na descrição dos processos de infiltração da água.

A Equação de Darcy também é válida para fluxo (infiltração) de água em solo não saturado,

$$
\begin{gathered}
q=K \cdot \operatorname{gradh} \\
q=-\frac{k}{\mu}\left(\frac{\partial p}{\partial z}-\rho g\right)
\end{gathered}
$$

onde,

$q$ é a velocidade de Darcy $(\mathrm{m} / \mathrm{s})$

$K$ é a condutividade hidráulica $(\mathrm{m} / \mathrm{s})$

$h$ é a carga hidráulica $(\mathrm{m})$

$k$ é a permeabilidade intrínseca do solo $\left(\mathrm{m}^{2}\right)$, que depende das dimensões e da geometria e organização interna dos poros no solo: $K=k \cdot \rho g / \mu, K$ é a condutividade hidráulica e $\rho g / \mu$ é o grau de viscosidade do fluido.

$\mu$ é a viscosidade dinâmica da água (centipoise)

¡ é a pressão da água no interior do solo $\left(\mathrm{g} / \mathrm{m}^{2}\right)$

oz é a profundidade $(m)$

$\rho$ massa específica da água $(\mathrm{g})$ 
g aceleração da gravidade $\left(\mathrm{m} / \mathrm{s}^{2}\right)$

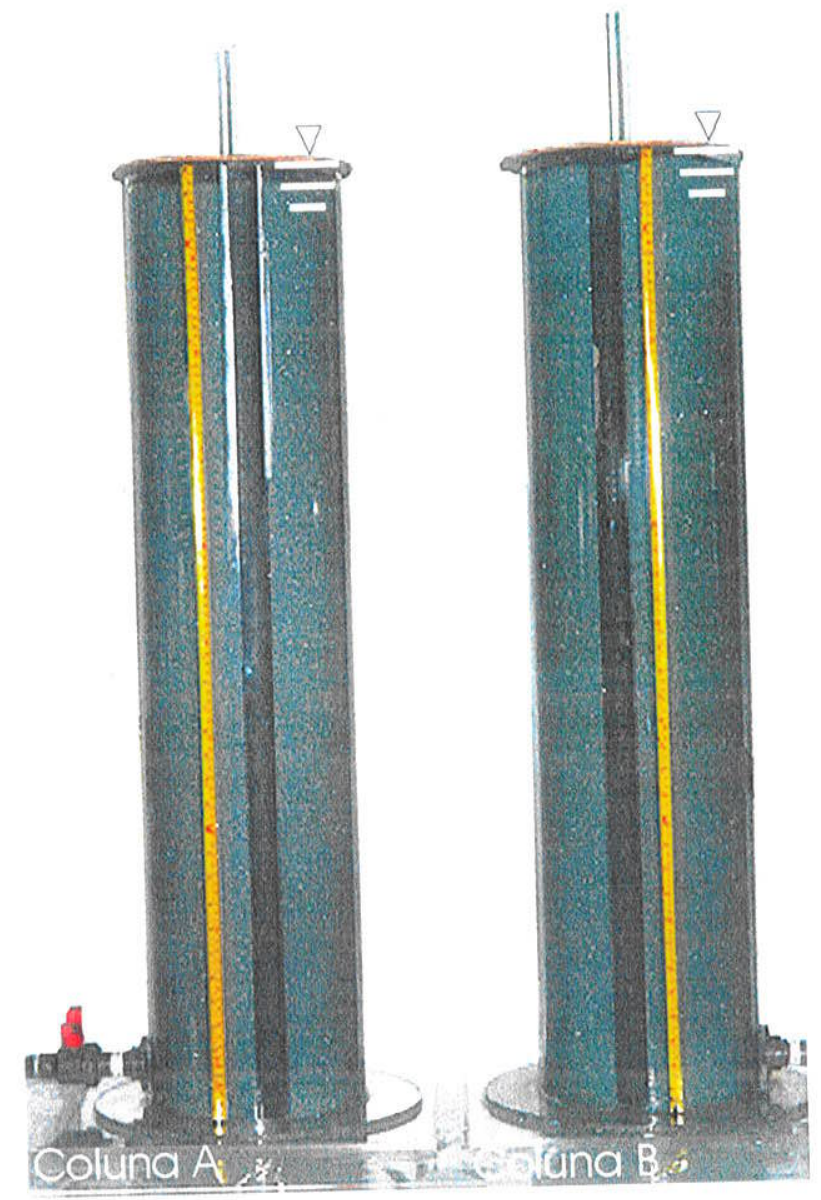

Figura 2.4 - Colunas com saturação completa

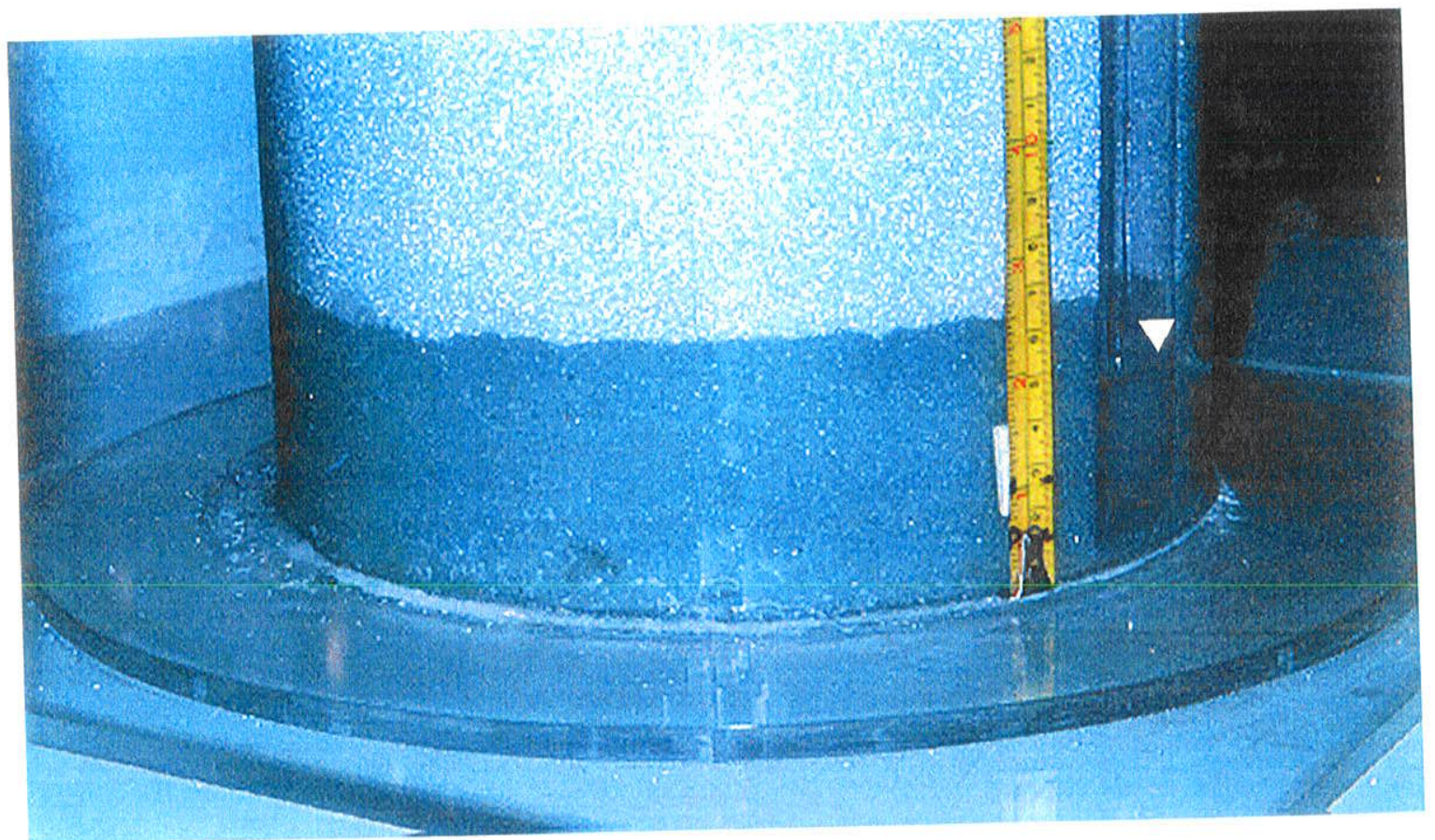

Figura 2.5 - Frente molhante uniforme 
A extensão da lei de Darcy para solos não saturados exige que sejam redefinidas a condutividade hidráulica e a carga hidráulica (Silveira, 1992). Essa, por exemplo, varia com o teor de umidade do solo, tendo como limite superior a $K_{\text {sat. }} A$ carga hidráulica, por sua vez tem dois componentes principais em solo não saturado:

$$
h=\varphi+z
$$

onde,

$\varphi$ é o potencial matricial ou de capilaridade

$z$ é o potencial gravitacional (profundidade)

As Equações 2.1 e 2.2 vêm mostrar que apesar dos princípios físicos e do fluido serem os mesmos para as duas zonas, há diferenciação na infiltração da água em solos saturados e não saturados. Do mesmo modo, também há condições de contorno que regem a infiltração da gasolina na zona não saturada que distinguem-se do comportamento do combustível na zona saturada.

Para o processo descrito onde a água expulsa o ar dos poros dá-se a designação de imbibição, termo utilizado na hidrogeologia para designar o processo em que o fluido molhante expulsa o fluido não molhante.

Seguindo o mesmo procedimento empregado para saturação da coluna, houve a dessaturação. Desta vez o tambor foi posicionado no nível da base da coluna e o escoamento de água do sistema regulado pela válvula.

A medida que houve rebaixamento do nível d'água houve efeito da mudança de pressão no conteúdo volumétrico, tendo a superfície dos "sedimentos" como datum. A Figura 2.6 mostra a relação conteúdo de água/ pressão de carga, (Gillham, 1984):

Posição 1: nível d'água acima do nível dos sedimentos: o sedimento está saturado e a superfície tem pressão de carga de $\mathrm{h}=+2 \mathrm{~cm}$.

Posição 2 : nível d'água coincidente com superfície do pacote sedimentar: a água em excesso foi drenada. A pressão da água na superfície do solo é a pressão atmosférica e assim a pressão de carga é $\mathrm{h}=0$. Devido a este valor, não há diferença de pressão através da interface ar/água, resultando uma interface reta.

Posição 3: nível d'água abaixo da superfície resulta em pressão de carga negativa ou sucção aplicada a água na camada superior do solo $\mathrm{h}=-10 \mathrm{~cm}$ (altura da coluna de sedimento acima do NA). A água é drenada dos poros, formando uma interface curva com o ar que a expulsa por aumento da diferença de pressão na interface. A água será drenada até 
o raio da curvatura ser suficientemente pequeno para causar uma diferença de pressão através da interface que irá equilibrar a pressão de carga negativa aplicada. Esta diferença de pressão é dada pela fórmula da capilaridade (elevação capilar):

$$
h=\frac{2 \sigma}{\rho g r} \cos \theta
$$

onde,

$\sigma$ é a tensão superficial da água [N/L]

$\rho$ é a densidade da água $\left[\mathrm{M} / \mathrm{L}^{3}\right]$

$g$ é a aceleração da gravidade $\left[\mathrm{L} / \mathrm{T}^{2}\right]$

$r$ é o raio de curvatura do menisco $[\mathrm{L}]$

$\theta$ é o ângulo do fluido com o sólido

Esta Equação expressa a diferença de pressão, em unidade de carga, sobre a superfície do solo. Ao assumir o ângulo entre o menisco e o sólido ( $\theta$ ) de valor zero o fluido torna-se perfeitamente molhante. A Equação 2.3 deixa de apresentar o cosseno, $\cos \theta=1$.

Nesta posição a água escoada causa diminuição do menisco nos poros, como visto na Figura 2.6, mas o solo mantém-se muito próximo da saturação, mas com pressão de carga negativa, $\mathrm{h}=-10$.

Posição 4: similar a posição 3, exceto pelo menisco mais côncavo nos poros, resultando em menor raio de curvatura que é capaz de equilibrar a maior pressão negativa aplicada.

Posição 5: a pressão é $\mathrm{h}=-35 \mathrm{~cm}$, o raio do poro é muito grande para manter o raio do menisco necessário ao equilíbrio da pressão aplicada, e assim o poro se esvazia. Isto resulta no decréscimo do conteúdo volumétrico de água, na pressão de carga igual a $-35 \mathrm{~cm}$. Como a pressão de carga torna-se progressivamente mais negativa, a drenagem atinge os poros menores diminuindo o conteúdo volumétrico de água no solo. 


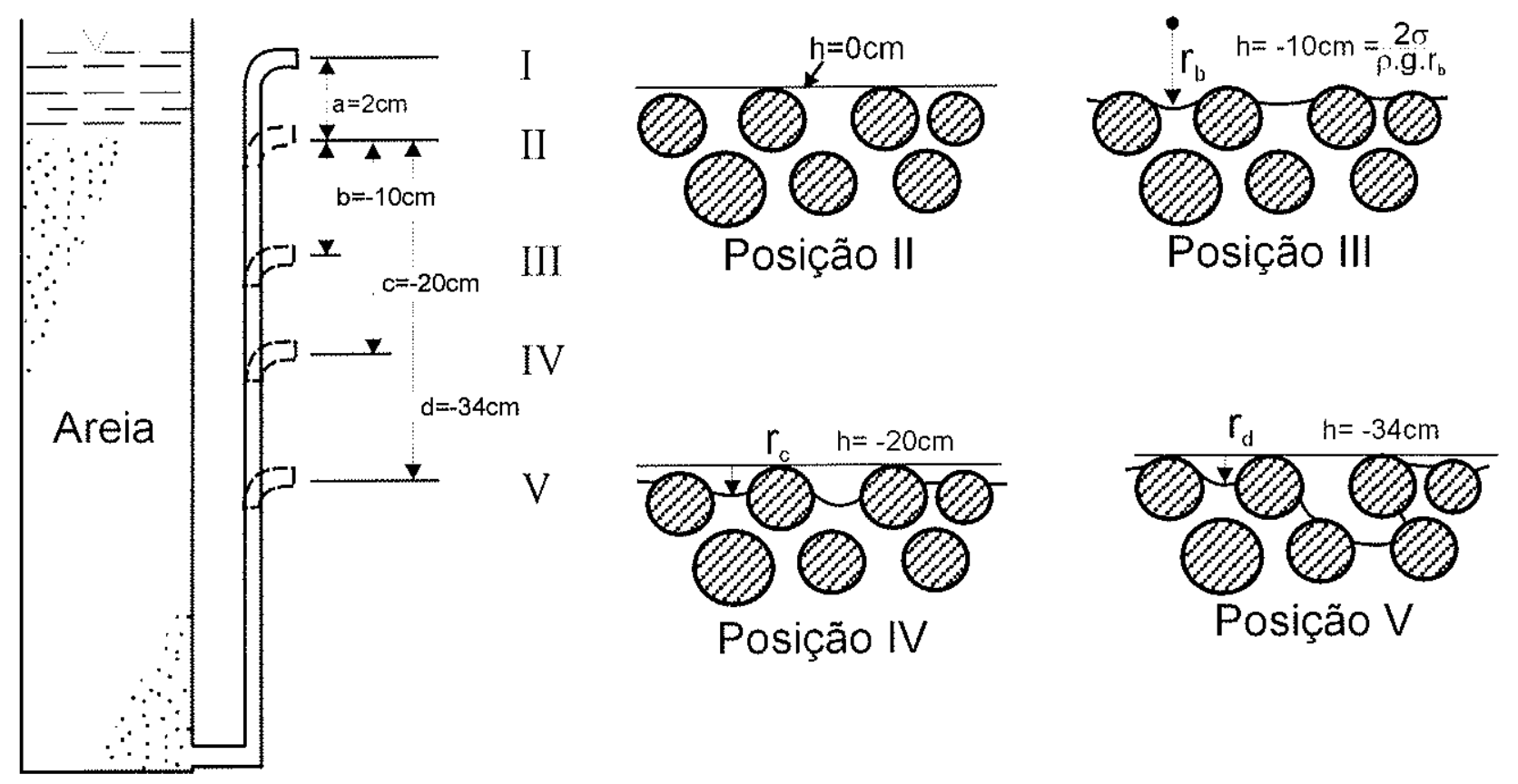

Figura 2.6 - Configuração microscópica no processo de drenagem (Gillham, 1984, adaptado)

O deslocamento da água pelo ar deve-se ao aumento da pressão de ar em relação a pressão de água no meio poroso. Contudo, no caminho da saída, a água se adere ao sólido formando uma força que resiste ao movimento. O resultado da aderência é representado com a formação do menisco e tensão na interface água/ar. Esta tensão (tensão interfacial) é uma força superficial por unidade de comprimento que atua no perímetro em direção tangente a superfície curva (Dullien, 1992), Figura 2.7a. Na interface esférica, figura 2.7b, a base da bolha está sob tensão e cada ponto da superfície está sujeita a pressões normais do lado de cada fluido. O efeito da tensão é reduzir o tamanho da esfera a menos que esta se oponha devido a grande diferença entre as pressões internas e externas, $\mathrm{P}^{\prime}$ e P". 


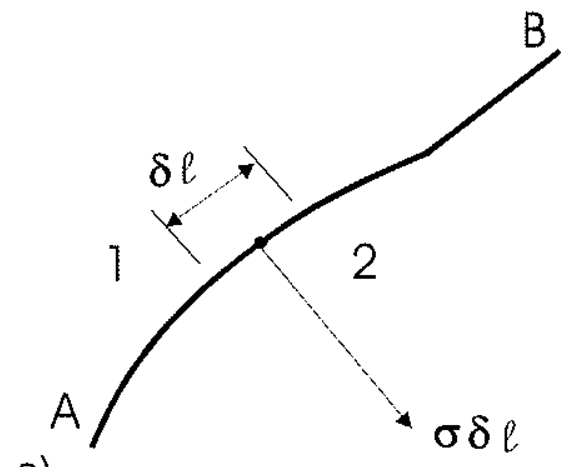

a)

Figura 2.7 - a) Definição de tensão interfacial, b) Equilíbrio capilar em superfície esférica (Prigogine e Defay, 1996, in Dullien, 1992)

Neste processo chamado de drenagem, tem-se que sob pressões capilares baixas (pressões iniciais) a água desocupa primeiro os poros de raios maiores. Com migração gradativa, a medida que a pressão capilar aumenta o conteúdo volumétrico de água $(\theta)$ diminui,

$$
r=\frac{2 \sigma}{P c} \quad \Rightarrow \quad \theta \propto \frac{1}{P c}
$$

Após ser drenada dos poros maiores, o progresso da expulsão de água pelo ar leva a água a ocupar os poros menores. Em razão proporcional há diminuição da umidade $\mathrm{e}$ aumento da diferença de pressões, Equação (2.4). Se a pressão do ar, $P_{a r}$, for nula, para Pc $=P_{a r}-P_{\text {água }}$ tem-se que $\mathrm{Pc}=-P_{\text {água }}$ O sinal negativo indica sentidos opostos, ou seja, a água fica retida nos vazios do solo por tensão/sucção. A água ao ser drenada pela gasolina oferece resistência como resposta a força de sucção. A gasolina deve aplicar uma energia que supere a força de sucção a fim de expulsar a água dos poros.

Ainda sob drenagem, os poros sob condições de pressão capilar baixa ligados a gargantas sob alta pressão retêm o volume de água no seu interior. Esta é a chamada saturação irredutivel, propriedade do meio poroso.

Em caráter macroscópico, o movimento da água subterrânea é dotado de complexidades envolvendo constantes do fluxo. Para utilizar a equação que melhor descreve o fluxo de água, desconsiderou-se as condições de contorno e legitimou-se o fluxo em função da condutividade hidráulica, área e deslocamento resultando na velocidade de Darcy. $A$ velocidade da água subterrânea é a descarga $(q)$ dada pelo volume $(V$ que passa na área total (A) (grãos e poros) no tempo $(\Delta t)$ : 


$$
q=\frac{V}{A \cdot \Delta t}=\frac{Q}{A}
$$

O rebaixamento no nível dágua prosseguiu até $47 \mathrm{~cm}$, a contar da superfície da coluna, e formação de franja capilar, $12 \mathrm{~cm}$ acima do nível d'água. Neste patamar, o fluxo de água no sistema foi interrompido. Mas o nível d'água não permaneceu com este valor. $O$ sistema descansou até o equilíbrio das forças gravitacional e capilar ser estabelecido. Assim, o nivel d'água estacionou em $58,6 \mathrm{~cm}$ para coluna $A$ e $62,3 \mathrm{~cm}$ para coluna $B$, a contar da base. A altura da franja acompanhou a elevação obtendo a posição final a $64,4 \mathrm{~cm}$ na coluna A e $67,8 \mathrm{~cm}$ na coluna $B$.

Este procedimento de saturação total e posterior rebaixamento foi realizado com o intuito de formar uma frente molhante e fornecer ao meio o fator conteúdo volumétrico de água $(\theta)$. Larson et al (1981) observou que a pressão capilar depende da saturação prévia da amostra.

\section{2 - Estimativa do nível de combustível}

O cálculo da profundidade alcançada pela gasolina no sistema permitiu o controle da posição do combustível para ajuste das medidas ao padrão das colunas.

A posição do nível d'água no meio poroso é determinada pela carga d'água que é necessária para suportar a coluna de gasolina no poço. Esta medida é o produto da espessura da gasolina no poço e a razão das densidades da água e do combustível. Assim a profundidade, abaixo do nível d'água, em que a gasolina alcança o equilíbrio no poço de monitoramento pode ser calculada. Em equilibrio, a pressão da gasolina no $P M, P_{g}$, e a pressão da água, $P_{a}$ á devem ser iguais,

$$
\begin{gathered}
\mathrm{P}_{\mathrm{g}}=\mathrm{P}_{\mathrm{a}} \\
\rho_{\mathrm{g}} \cdot \mathrm{E}_{\mathrm{g}}=\rho_{\mathrm{a}} \cdot \mathrm{D}_{\mathrm{NA}} \\
\mathrm{D}_{\mathrm{NA}}=\left(\frac{\rho_{\mathrm{g}}}{\rho_{\mathrm{a}}}\right) \cdot \mathrm{E}_{\mathrm{d}}
\end{gathered}
$$

onde,

$\rho_{g} \quad e \quad \rho_{\dot{a}}=$ densidades da gasolina e água $(\mathrm{g} / \mathrm{mL})$

$E_{d}=$ espessura da gasolina no poço de monitoramento $(\mathrm{cm})$ 
$D_{N A}=$ diferença entre o patamar do nível d'água antes e depois da gasolina $(\mathrm{cm})$

Para valores das densidades iguais a $0,996 \mathrm{~g} / \mathrm{mL}$, para água, $0,740 \mathrm{~g} / \mathrm{mL}$, para gasolina pura, e $0,720 \mathrm{~g} / \mathrm{mL}$, para a E-24, e estimando uma espessura média de $15 \mathrm{~cm}$ de gasolina no poço tem-se o rebaixamento do NA de $11,1 \mathrm{~cm}$ para coluna $A$ e $10,8 \mathrm{~cm}$ para coluna $B$, não incorrendo em extrapolação superior ou inferior das medidas da coluna.

$\mathrm{Na}$ comparação com os valores reais de rebaixamento, $8,4 \mathrm{~cm}$ para coluna $A$ e $4,2 \mathrm{~cm}$ para coluna B, Figuras 2.8 e 2.9 , tem-se uma diferença de $2,7 \mathrm{~cm}$ para o rebaixamento promovido pela gasolina pura e de $6,6 \mathrm{~cm}$ para a E-24. Entretanto, visto que a espessura real da lâmina não foi a estimada, $15 \mathrm{~cm}$, mas $15,6 \mathrm{~cm}$ para coluna $A$ e $12 \mathrm{~cm}$ para coluna $B$, refazendo os cálculos tem-se a nova estimativa de $11,6 \mathrm{~cm}$ em $A$ e $8,7 \mathrm{~cm}$ em $B$.

Mesmo após o cálculo para a espessura real encontrada no experimento viu-se uma diferença de $3,2 \mathrm{~cm}$ para coluna $A$ e $4,5 \mathrm{~cm}$ para coluna $B$. Alia-se a diferença aos efeitos da tensão interfacial, desprezados na Equação (2.11). 


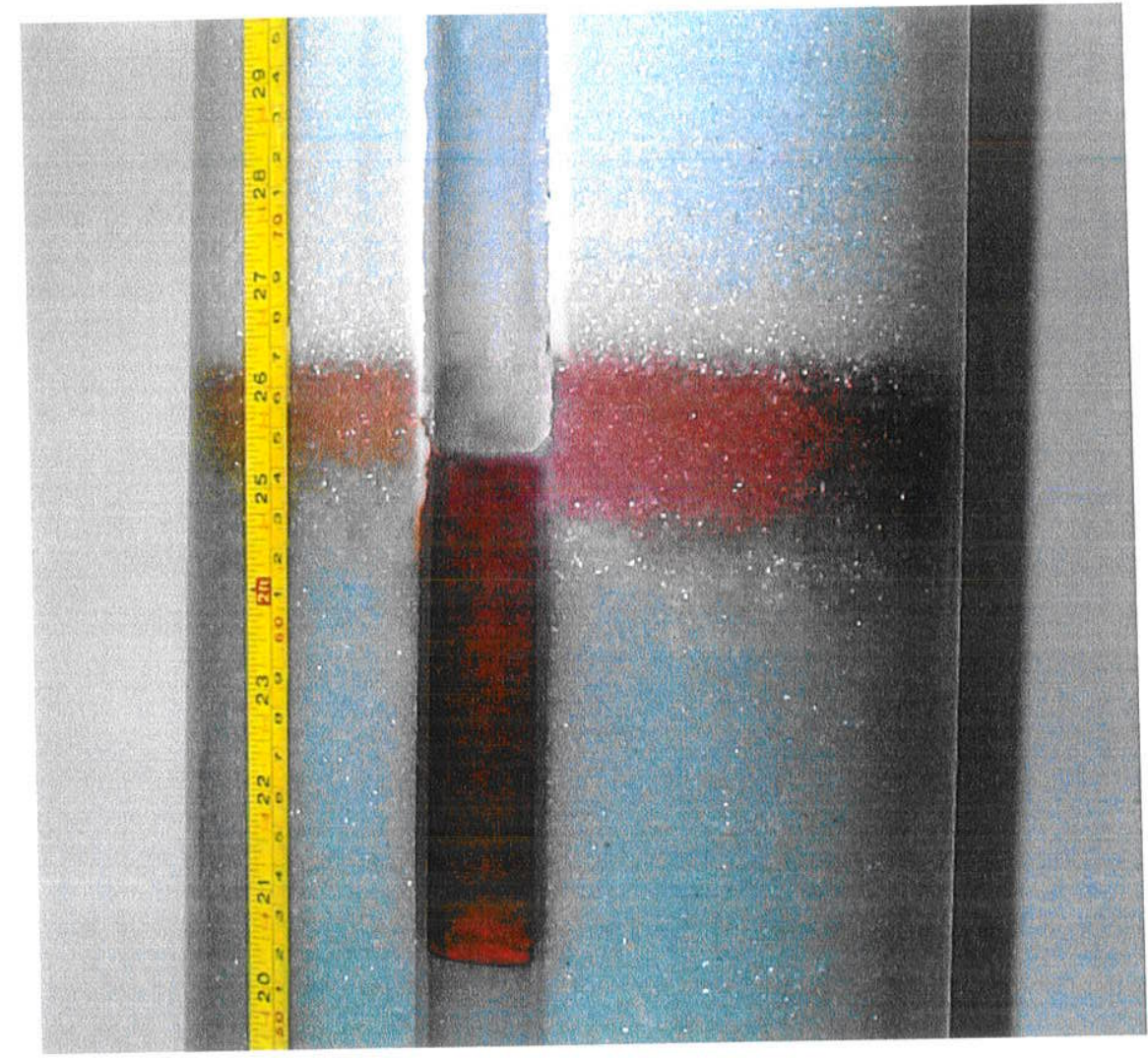

Figura 2.8 - Rebaixamento do nível d'água devido a injeção de gasolina pura, Coluna A

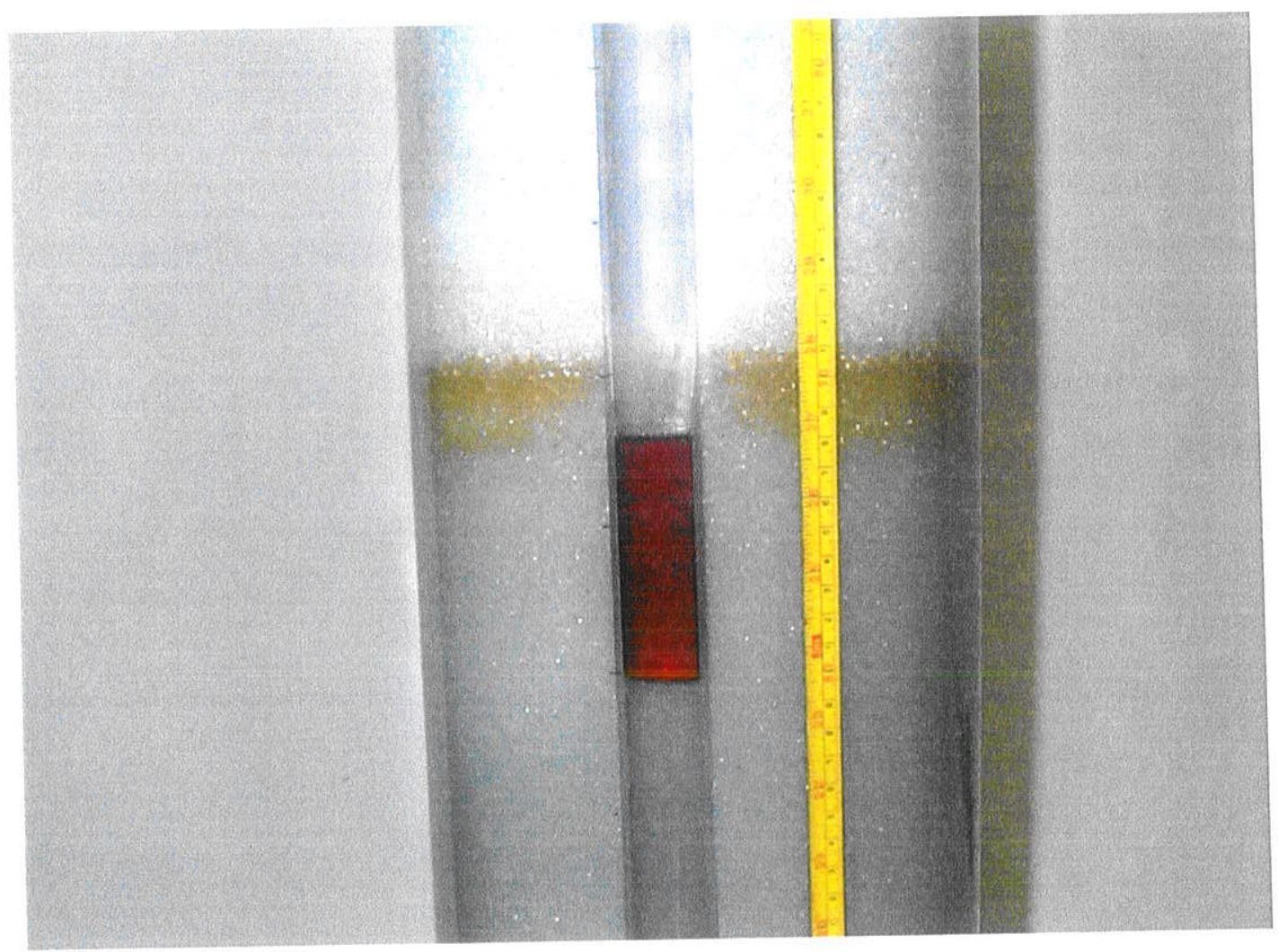

Figura 2.9 - Rebaixamento do nível d'água devido a injeção de E-24, Coluna B 


\section{Capítulo 3 \\ RELAÇÕES MICROSCÓPICAS E MACROSCÓPICAS}

\section{1 - Geometria}

A interação entre os fluidos neste trabalho é realizada segundo pressões internas e externas, forças relativas ao meio poroso e ângulos de contato entre as substâncias e com o meio sólido. A seguir serão vistas estas relações.

A água está disposta no meio hidrofilico de duas maneiras, armazenada em grandes volumes e sujeita ao fluxo hidrodinâmico, na zona saturada do aquifero, e, em quantidade inferior, na forma de umidade do solo, onde divide espaço com o ar e vapor d'água na zona não saturada. As formas adquiridas pela água no meio poroso variam com a quantidade e distância com os grãos do solo. Na Figura 3.1, tem-se a formação de anel pendular para grãos próximos e ponte pendular para grãos afastados na zona não saturada. $\mathrm{Na}$ zona saturada a água sempre apresenta-se em lentes insulares, cobrindo toda a superfície dos grãos do solo.

a)

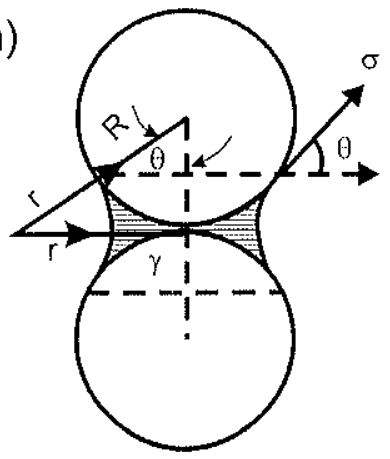

b)

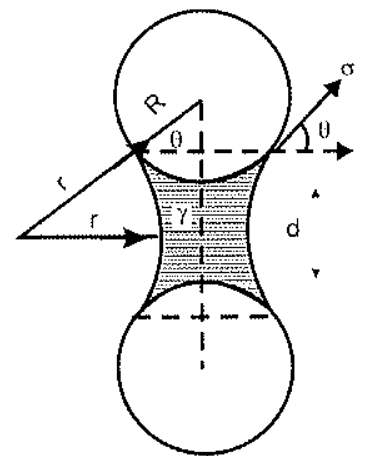

Figura 3.1 - a) Forma de anel pendular e b) ponte pendular para água (Dullien, 1992)

A interação entre a matriz do solo e a água nos poros é dada pelo potencial matricial Junto com as forças de adsorção e capilaridade, que agem na retenção do líquido no solo. Quando liberada no solo, a gasolina tende a expulsar a água presa nos poros. Devido as forças de coesão entre os grãos do solo e a água, a gasolina deve desenvolver energia suficiente para diminuir as forças de coesão e assim preencher todo o espaço poroso. Esta - energia será tanto maior quanto mais baixa a umidade do solo. Libardi (1995) nota que na 
condição de saturação total, as forças matriciais não atuam, são nulas, e na zona não saturada são sempre negativas.

A energia retida na interface entre os fluidos varia (aumenta) com a diferença entre a distância entre as moléculas sujeitas a atração (no interior de cada fluido) e as moléculas da área de contato entre as substâncias. Quando a superfície que contém a energia é contraída a energia manifesta-se em forma de tensão interfacial (Bear, 1972). Esta pode ser também conceituada como a quantidade de trabalho que deve ser aplicado para separar em uma unidade de área os dois fluidos imisciveis.

Quando apenas a água e o ar/vapor d'água estão presentes no meio poroso hidrofilico diz-se que o líquido é o fluido molhante e a fase gás é o fluido não molhante da relação, Figura 3.2. Estas designações correlacionam os ângulos entre fluidos envolvidos e o solo. Assim na análise de um sistema de três fases (sólido e dois fluidos) por meio da relação de intensidade entre as forças moleculares (London-van der Waals de coesão e atração) se determina se o ângulo formado entre o plano tangente à superfície líquida na linha de contato e a parede do recipiente será reto, agudo ou obtuso.

Ängulo de Contato $>90^{\circ}$

Líquido "repele" o Sólido

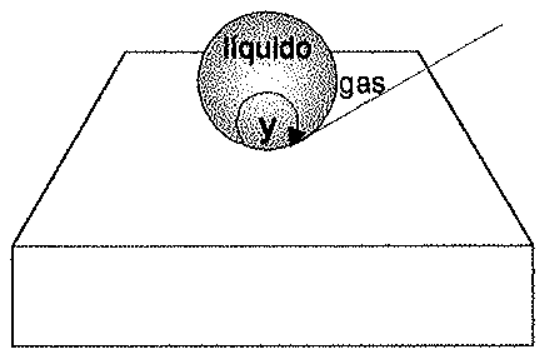

Ângulo de Contato $<90^{\circ}$

Líquido "molha" o sólido

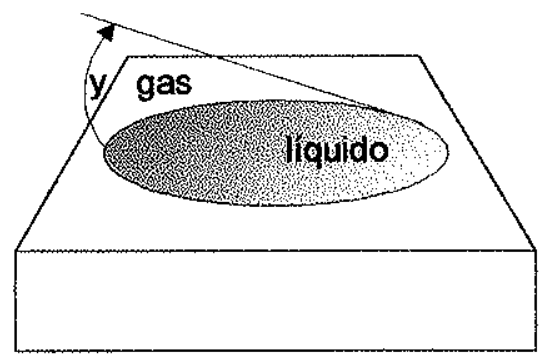

Figura 3.2 - a) fluido não molhante, e b) fluido molhante

As forças que agem no ponto de contato entre dois fluidos imisciveis e parede de um capilar podem ser vistas na Figura 3.3. ' $M$ ' é o ponto de coincidência entre os fluidos e o capilar. A resultante das forças de coesão do fluido ' $A$ ' que atua no lado do contato com o sólido é representado por $F_{c}, F_{a}$ é a resultante das forças de adesão, e $F$ é a força resultante entre $F_{c}$ e $F_{a}$. A força da gravidade é desprezada em vista das proporções microscópicas das relações. $O$ ângulo $\theta$, medido a partir do fluido mais viscoso, define a configuração do menisco formado entre os fluidos. 
Na Figura 3.3a:

a) coesão do fluido $A$ é maior que a adesão entre este e o sólido, a resultante $F$ tende para o interior do fluido $A$,

b) o equilíbrio é firmado quando a superficie do fluido em $M$ encurva-se na direção da força resultante adquirindo a forma convexa e o ângulo maior que $90^{\circ}$.

c) fluido A "não molhante"

Na Figura 3.3b:

a) a força de adesão entre o sólido e o fluido A é superior a força de coesão deste fluido, a resultante final $F$ tende para o interior do sólido,

b) alcance do equilibrio quando a superfície encurva-se na direção da resultante adquirindo forma côncava e ângulo de contato menor que $90^{\circ}$.

c) fluido A "molhante"

Quando a resultante das forças moleculares atuantes em $\mathrm{M}$ é paralela à parede, 0 ângulo de contato $\theta=90^{\circ}$ resultando no espalhamento infinito dos fluidos sobre o sólido.

a)

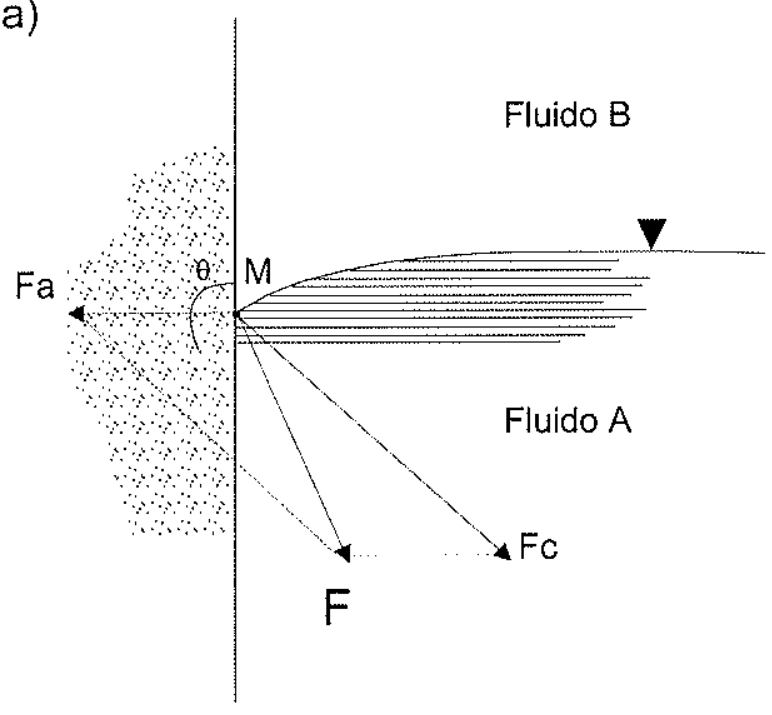

b)

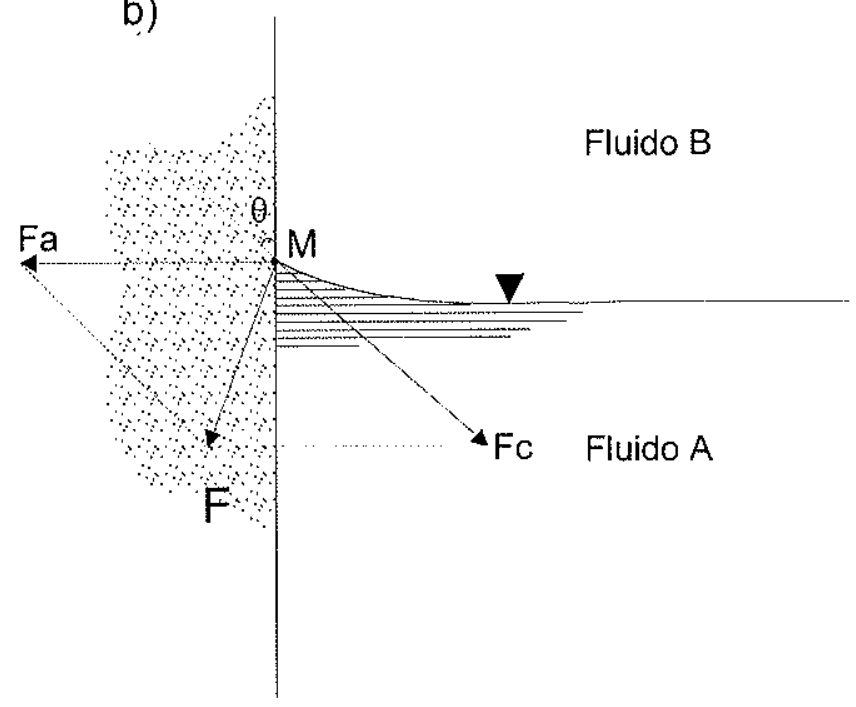

Figura 3.3 - Contato entre dois fluidos e o sólido ( Bear, 1979)

No entanto estes termos não são restritivos, há autores que estendem as definições referindo-se a molhabilidade mista ou ainda mudança de condições molhantes nos poros.

Larson et al (1981) ao referirem-se às rochas armazenadoras de petróleo utilizaram o termo molhabilidade heterogênea que pode ser bem aplicado neste estudo. Como o meio poroso é dotado de ramificações, mesmo considerando-o homogêneo e isotrópico, o caminho percorrido, seja pelo fluido molhante ou pelo não molhante, não obedece um padrão 
uniforme. Há frações do meio (fase sólida) que são preferecialmente molhados por um determinado fluido. Nas áreas da franja capilar, a presença da água em menor ou maior volume e a ordem de ocupação dos poros levam à molhabilidade heterogênea. Em uma determinada área da franja pode ser a água o fluido molhante e em outra a gasolina. Molhabilidade fracional e molhabilidade mista são outras designações utilizadas por Larson et al (1981).

Oliveira (1997) sugere ainda uma mudança de molhabilidade por conta da infiltração de etanol no meio poroso contendo inicialmente gasolina e água. O etanol penetra pelos poros, promove expulsão de parte da gasolina residual, que ocupa a quase totalidade do poro, e ao dissolver-se na água insular inicia o processo de formação de fase única (diagrama pseudoternário, Capítulo 1). Fase onde a água deixa de ser o fluido molhante, Figura 3.4 .
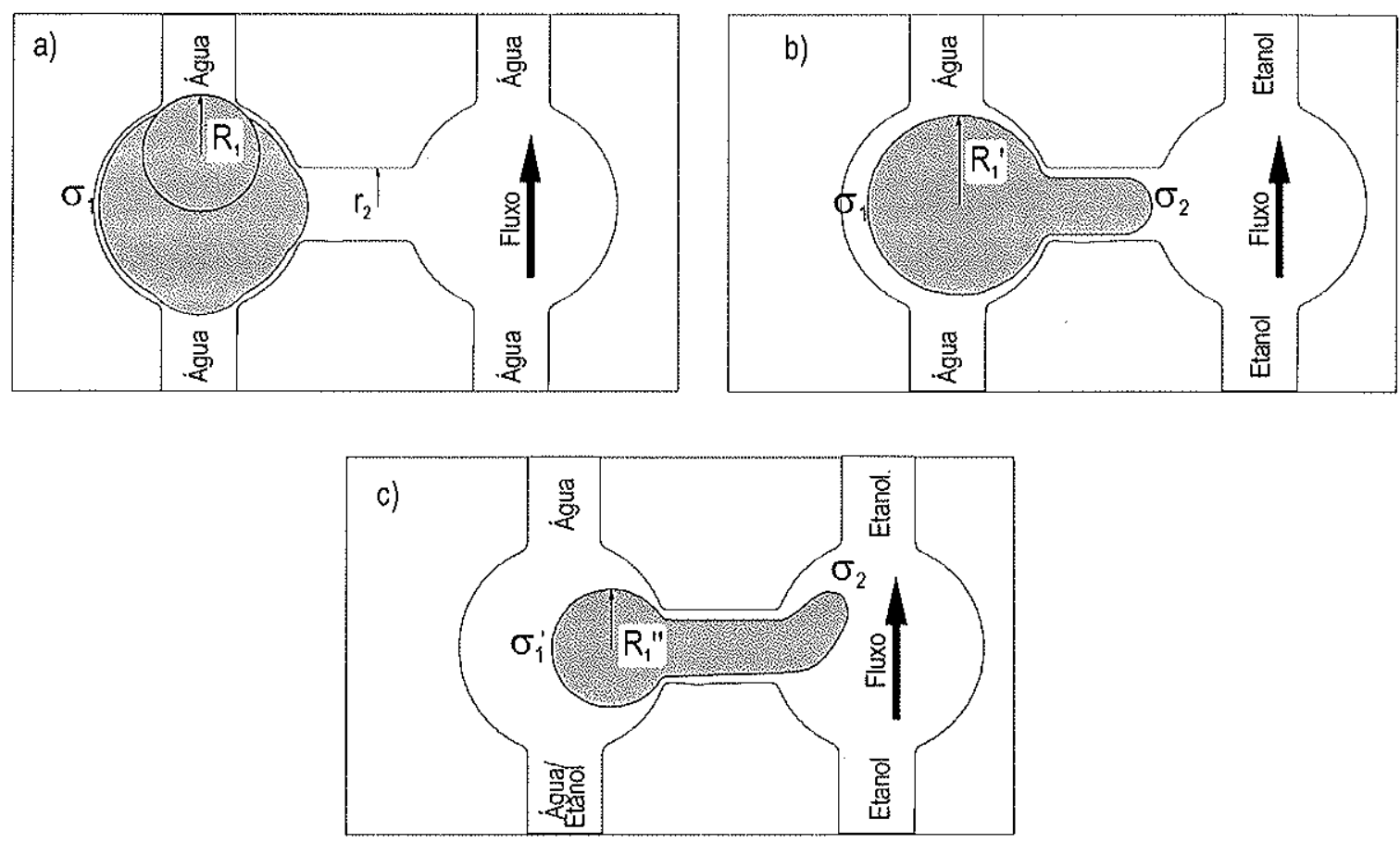

\footnotetext{
- = tensão interfacial

$\mathrm{r}_{2}=$ raio da garganta do poro

$\mathrm{R}_{1}=$ raio da bolha trapeada

$\square$ fase aquosa

2 gasolina

$\square$ grãos (meio poroso)
}

Figura 3.4 - Mudança de molhabilidade pela influência do etanol (Oliveira, 1997) 
Quando a fase livre ou residual da gasolina penetra no sistema monofásico (água) ou bifásico (água e ar/vapor d'água) tende a criar novas condições de adaptação ao local. A forma de interação será função do coeficiente de espalhamento, fator que prediz a geometria adquirida pela gasolina em relação ao sólido ou sobre a água, seja esta na zona saturada ou não saturada.

O Coeficiente de espalhamento determina se a gasolina formará lentes $\left(\mathrm{C}_{S \mathrm{~S}}<0\right)$ ou irá espontaneamente espalhar-se $\left(\mathrm{C}_{\mathrm{SP}}>0\right)$ na superfície da água. Este $\mathrm{C}_{\mathrm{SP}}$ depende dos valores da tensão interfacial para os sistemas ar/água $\left(\gamma_{a / a}\right)$, ar/gasolina $\left(\gamma_{a / g}\right)$ e gasolina/água $\left(\gamma_{s} / a\right)$ e é definido como, (Bear, 1979):

$$
C_{s p}=\gamma_{a b}-\left(\gamma_{k i}+\gamma_{o s}\right)
$$

Este parâmetro será considerado aqui com base em dados de literatura, sem análise quantitativa, uma vez que não houve medidas em laboratório.

O coeficiente de espalhamento bidimensional, $S_{2 d}$, estima se a gasolina formará lentes isoladas ou deslizará sobre a superfície plana da água na zona saturada. De maneira análoga, o coeficiente de derramamento tridimensional, $S_{3 d}$, foi desenvolvido para prever se a gasolina formará anéis pendulares ou lentes insulares sobre a configuração do aro pendular da água na zona não saturada (Hartz e Overcamp, 1996).

$$
\begin{aligned}
& S_{2 d}=\text { equação (3.1) }
\end{aligned}
$$

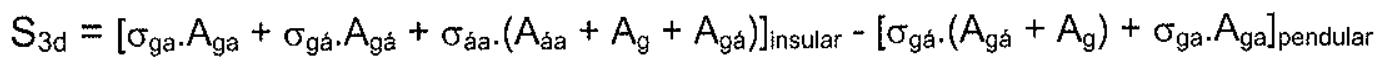

onde,

$\sigma_{\text {áa }}=$ tensão interfacial água/ar $[\mathrm{F} / \mathrm{L}]$

$\sigma_{\mathrm{ga}}=$ tensão interfacial gasolina/ar [F/L]

$\sigma_{\text {àg }}=$ tensão interfacial água/gasolina $[\mathrm{F} / \mathrm{L}]$

$A=$ áreas limitadas entre os fluidos $[L]$

A Tabela 3.1 resume estas relações: 
Tabela 3.1 Resumo das relações de coeficiente de derramamento bi- e tri-dimensional.

\begin{tabular}{|c|c|c|c|}
\hline Zonas & Forma & Fluido & Sinal \\
\hline \multirow{3}{*}{$\begin{array}{c}\text { Zona não saturada } \\
\qquad S_{3 d}\end{array}$} & Aros ou anéis pendulares & \multirow{2}{*}{ Molhante e não molhante } & $\begin{array}{c}\text { Positivo } \\
\text { Negativo* }\end{array}$ \\
\hline & Pontes pendulares & & Positivo \\
\hline & \multirow[t]{2}{*}{ Lentes insulares } & \multirow{3}{*}{ Não molhante } & Negativo** $^{* *}$ \\
\hline \multirow{2}{*}{$\begin{array}{c}\text { Zona saturada } \\
\mathrm{S}_{2 d}\end{array}$} & & & Positivo \\
\hline & Glóbulos esféricos & & Positivo \\
\hline
\end{tabular}

* Para regiões de alta tensão de molhante, ou seja, alta concentração em relação ao não molhante.

** Para regiões de baixa tensão de molhante, ou baixa concentração em relação ao não molhante. Segundo Hartz e Overcamp (1996) adquire a geometria insular ao ser imobilizado nos poros maiores.

As três primeiras formas da Tabela 2 contrastam com os glóbulos esféricos devido as condições de contorno que cercam o fluido não molhante nas duas zonas. Na zona saturada o fluido não molhante é submetido a tensão interfacial única em todos os pontos na interface água-gasolina. Na zona não saturada este fluido tem duas interfaces com diferentes tensões,

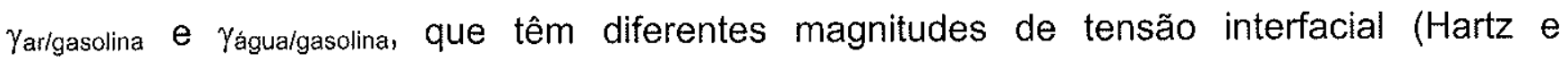
Overcamp, 1996).

O conceito de molhabilidade conduz a diferentes graus de saturação aliados a formas de acondicionamentodos fluidos (Bear, 1972):

- Situação de água molhante:

- Baixa saturação - aneis pendulares ao redor dos grãos em contato. A baixa saturação deixa os aneis isolados, mas a continuidade pode se dar através de filmes delgados de água que conduzem às outras suerfícies de outros grãos. Neste padrão praticamente não há pressão transmitida de um anel para o próximo dentro da fase aquosa.

- Aumento da saturação - progresso de aneis pendulares até a fase contínua do fluido ser ser formada. esta saturação é chamada saturação de equilíbrio da fase molhante, acima desta a água adquire a forma de funicular e favorece o fluxo.

Quando a saturação do molhante torna-se extensa o suficiente em relação ao não molhante quebra a continuidade deste nos grandes poros, diz-se nestes casos que o não molhante está no estado de saturação insular.

O mesmo raciocínio vale para situação em que a gasolina é o fluido molhante do meio. 
A Figura 3.5 mostra o contato entre os três fluidos envolvidos no sistema. 0 hidrocarboneto fica "preso" entre o ar, a água e o sedimento.

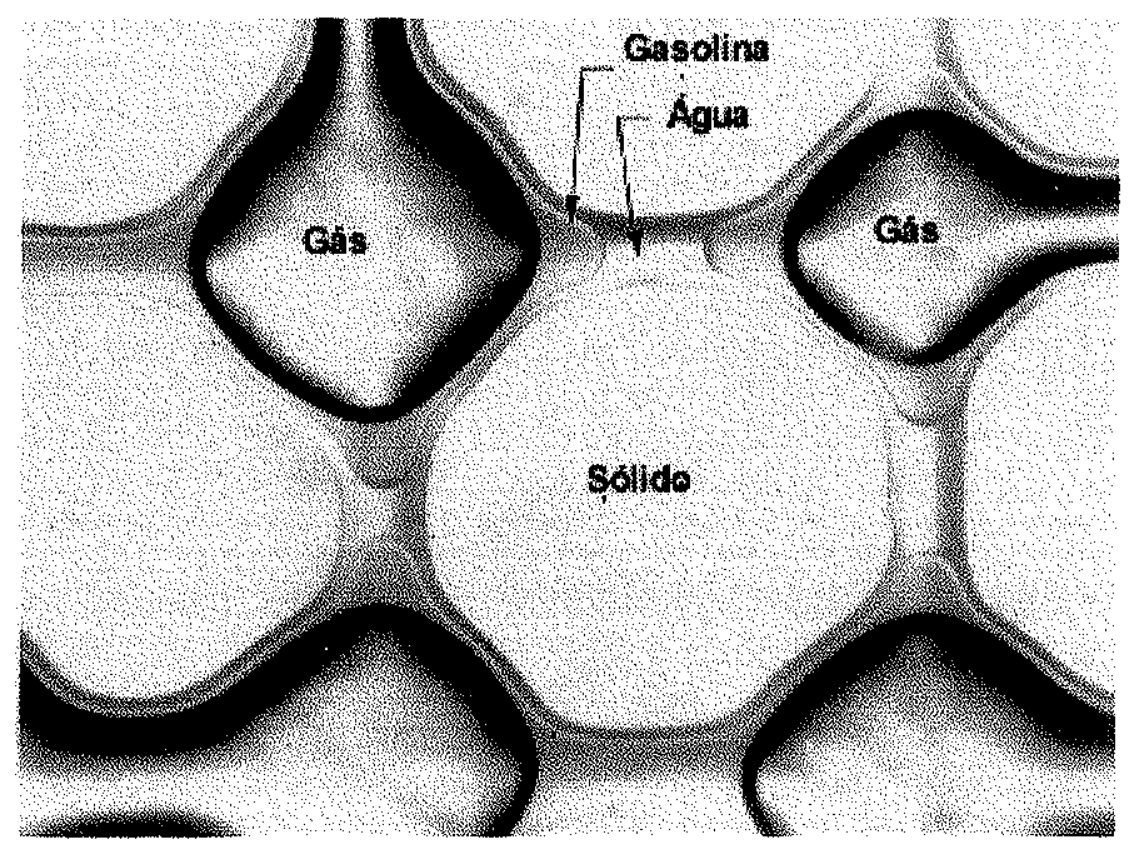

Figura 3.5 - Contato entre três fluidos e o sólido (Dullien, 1992)

O conhecimento destas interações e formas são ferramentas para cálculo do volume de combustivel presente no subsolo. Além de definir as possiveis forças atuantes na interface gasolina-água a fim de induzir a expulsão da gasolina dos poros.

Hartz e Overcamp (1996) agruparam as equações de Melrose (1966) e Byrd e Friedman (1971) para o cálculo da área e volume de anéis pendulares e lentes insulares a partir da superfície de revolução formada na interface dos fluidos imisciveis entre dois grãos. Para a geometria de anéis pendulares tem-se o cálculo da curvatura da interface, área lateral à interface, área total e volume da água e da gasolina como função da diferença de pressão entre os dois fluidos (pressão capilar). Na estimativa da geometria das lentes insulares Hartz e Overcamp (1996) têm equações do raio das lentes, volume e da área da lente formada por gasolina/ar e da lente sobre superfície pendular da água.

A pressão desenvolvida pelas formas pendular e insular é determinada pela equação de Laplace de capilaridade (Bear, 1972) que dá a diferença de pressão através da interface entre os dois flluidos imisciveis. 


$$
\delta P=\frac{2 \sigma}{R}
$$

onde,

$\delta P$ é a diferença de pressão na interface

$2 \sigma \dot{e}$ a tensão interfacial entre os fluidos imiscíveis

$R$ é o raio principal da curvatura da interface

O ângulo de contato entre os fluidos e entre este(s) e o sólido a partir do qual se evolui a superfície de revolução deve ser medido por meio da equação de Young

$$
\cos \phi_{n n}=\frac{\sigma_{i a}-\sigma_{i g}}{\sigma_{\mathrm{g} a}}
$$

Assume-se que a área da interface águamar antes do derramamento é igual a área da interface gasolina/água (arranjo pendular) imediatamente após o contato destes fluidos. A forma da curvatura na interface permanecerá a mesma, mas a tensão da água modificará devido a nova tensão interfacial. O conteúdo de umidade $(\theta)$ modificará gradualmente devido a vários processos, inclusive o fluxo do filme sobre a superfície dos grãos (Hartz e Overcamp, 1996). A injeção de gasolina pode provocar trapeamento de água e redução do volume do anel pendular de água.

Algumas técnicas de remediação utilizam água descontaminada (captada do aquífero, tratada e depois relocada) para promover expulsão de combustivel da zona não saturada. Schwille (1988) mostrou em experimento que a infiltração de água nestas zonas pode causar encurralamento do líquido não molhante. Neste caso o método aplicado além de ineficiente é também um agravante à contaminação. A quebra da geometria formada pelos combustiveis, após infiltração da água, leva o contaminante a descrever movimentos descendentes para o contato com a água subterrânea e desta maneira aumentar o quadro de contaminaçao local.

\section{2 - Franja Capilar}

A franja capilar, ambiente de injeção direta das gasolinas neste trabalho, varia de espessura com as propriedades do solo e uniformidade do tamanho dos poros (Bear, 1972). Na literatura, esta região representa o final da zona não saturada, mas por estar na interface das zonas saturada e não saturada possui características, quanto a umidade, que abrangem ambas. Os poros dos sedimentos têm o grau de saturação crescente com a profundidade, há 
decréscimo gradual do conteúdo de umidade até a saturação quase completa logo acima do nível d’água (limite da zona saturada).

Gillham (1984) definiu a franja capilar como zona saturada por tensão, mostrando a dependência desta zona com a textura e caracteristicas estruturais do solo. Mostrou ainda que a franja capilar pode ter uma grande influência no processo de geração de fluxo, transporte de contaminantes para águas superficiais e transporte de contaminantes em regimes hidrogeológicos de nível d'água raso. Por esta zona ter pouca ou nenhuma capacidade de armazenamento em sedimento arenoso, quando estende-se até a superfície (aquífero freático), a infiltração de pequeno volume de água pode causar uma alta e rápida elevação do nível d'água. Este aumento por sua vez pode resultar em um rápido aumento no gradiente hidráulico e na área de descarga da água subterrânea (Gillham, 1984). Esta afirmação pode ser visualizada nas Figuras 3.6.

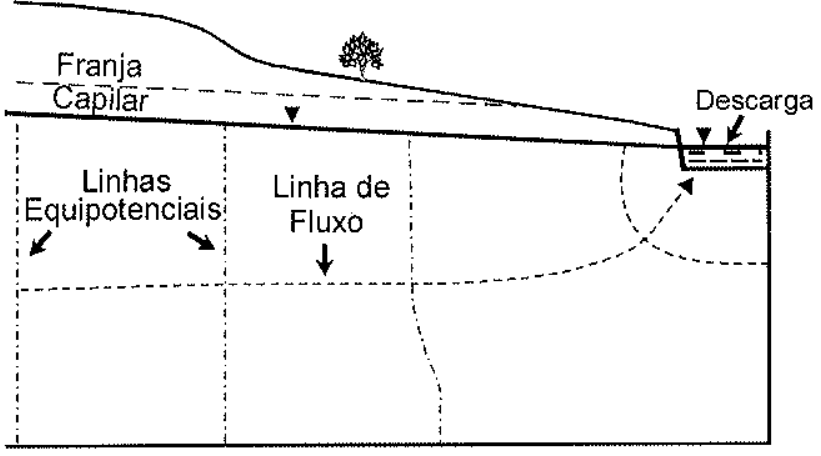

a

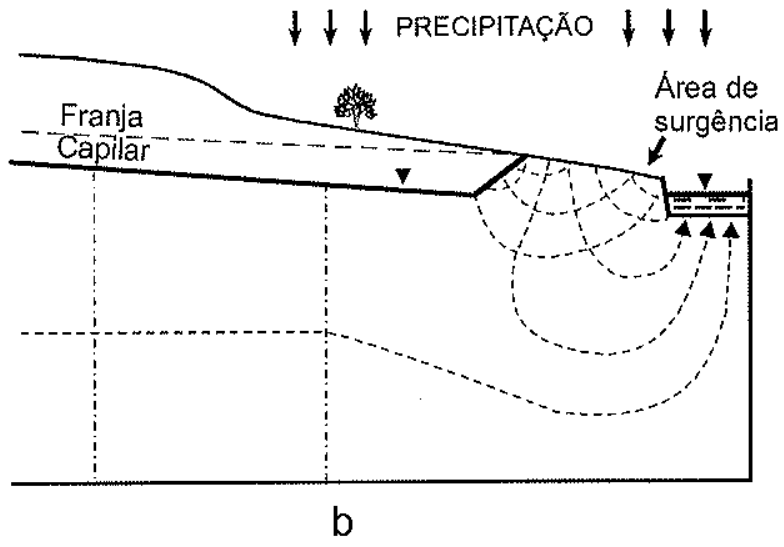

b

Figura 3.6 - Efeito da franja capilar na área de descarga de água subterrânea para águas superficiais, a) antes da chuva, e b) imediatamente após a chuva (Gillhan, 1984).

No experimento desenvolvido por Abdul e Gillham (1984), a importância da franja capilar foi demonstrada relacionando a precipitação e escoamento superficial. Observou-se que com a área de influência da franja capilar alcançando a superfície do terreno e em terrenos não planos parte de contaminantes dispostos na superfície pode infiltrar ou escorrer até alcançar águas superficiais ou subterrâneas em curto tempo. O fator precipitação favorece o contato entre contaminantes e a água, independente do índice pluviométrico, Figuras 3.7. Os trabalhos de campo mostram que a franja capilar afeta a elevação do NA em aquíferos freáticos, e quanto mais fina a granulometria maior o efeito. 

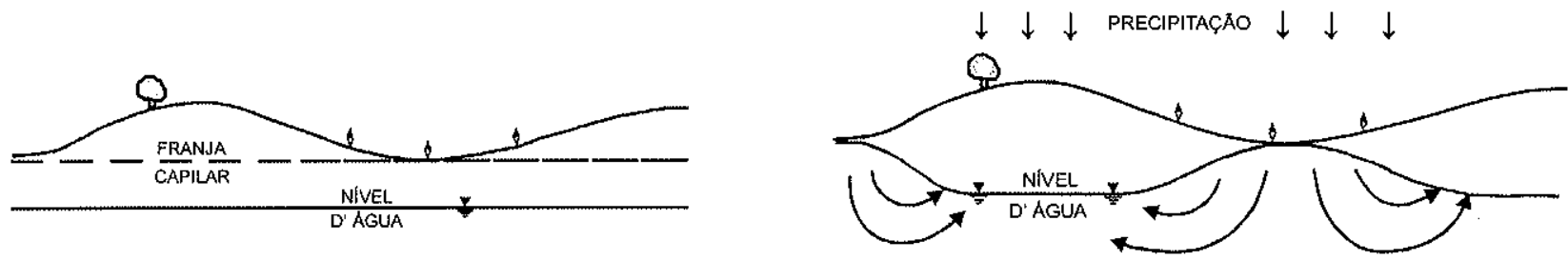

Figura 3.7 - Efeito fa franja capilar em resposta ao nivel d'água em áreas de topografia irregular (Gillham, 1984)

Casos assim, onde a franja capilar estende-se até a superfície do solo (nível d'água raso), o efeito do sistema de fluxo e geração de corrente é instantânea. Em nível d'água a maior profundidade a resposta é mais lenta. $\mathrm{O}$ argumento tem como suporte um experimento de campo (Abdul e Gillham,1984), onde $0,3 \mathrm{~cm}$ de água (precipitação) causou uma elevação de $30 \mathrm{~cm}$ na água subterrânea em 0,25 min, demonstrando assim a influência transiente da franja capilar na posição do nível d'água. Pesquisas vêm demonstrando que em aquíferos freáticos o aumento real do nível d'água é maior de que o previsto por meio de cálculos com porosidade específica (Specific Yield). Esta desproporcionalidade é atribuída ao aumento na pressão da fase gás na zona não saturada acima do nível d'água durante o processo de infiltração.

Uma segunda explicação pode ser correlacionada à variação da porosidade específica entre a superfície do terreno e o nivel d'água, maior e menor respectivamente. Este fato está relacionado à variação da umidade do solo acima do N.A. e à relação pressão de carga/umidade para cada tipo de solo.

A água de chuva, de acordo com o índice pluviométrico, é um agente de transporte de contaminantes para o aquifero. $O$ aspecto crítico é o correct rainfall condictions, que significa alta intensidade de chuvas em um curto período de tempo, resultando em empoçamento e subsequente infiltração. A precipitação média que cai em um longo período de tempo pode não ter impacto significante de contaminação, porque sob essas condições o nível da superficie de água empoçada e a subsequente infiltração estarão limitadas.

Além da precipitação como meio de carreamento de contaminantes tem-se o fluxo de água subterrânea outro agente de expansão dos compostos tóxicos. A utilização da equação de advecção-dispersão assume o fluxo de campo estável, consideração ideal, mas que desconsidera a variação do nivel d'água. Os contaminantes em água superficial impõem 
maior preocupação quando interferem no fornecimento de água limpa ou quando retornam à biosfera. Este retorno é proporcionado no carreamento para zona de descarga da água subterrânea, caracterizada por niveis d'água rasos.

Os princípios físicos associados com o fenômeno da franja capilar são a capilaridade e a pressão de carga. O primeiro por ascensão da água da zona saturada, como já descrito no Capítulo 2, através dos capilares formados pela rede de poros. A pressão de carga efetua a distribuição da água com referência à saturação. Os fluidos na franja capilar estão presos principalmente por forças capilares e diz-se que estão sob sucção.

\subsection{1 - Determinação da franja capilar}

Por convenção, $h_{c c}$ é determinada como a elevação da franja capilar no aqüifero a partir da zona saturada. Polubarinova-Kochina $(1952,1962)$, in Bear (1979), propuseram uma equação para o cálculo do $h_{c c}$ em centímetros,

$$
h_{c c}=\frac{0,45}{d_{10}} \frac{1-n}{n}
$$

onde,

$d_{10}$ é o diâmetro efetivo das partículas no meio poroso $(\mathrm{cm})$

$n$ é a porosidade efetiva do meio

Considerando-se o cálculo para porosidade igual a $30 \%$ e o diâmetro efetivo das micro esferas a $850 \mu \mathrm{m}(0,085 \mathrm{~cm})$, tem-se da Equação (3.3) o valor de $12,2 \mathrm{~cm}$ a elevação da franja capilar. Baseado neste cálculo, estimou-se a elevação do nível d'água e altura de injeção das gasolinas nas colunas a fim de que a espessura da fase livre não excedesse a altura da coluna ou alcançasse o piso da mesma.

O método analítico efetuado por Oliveira (1997) para o levantamento da espessura da franja capilar, utilizando-se experimento de laboratório e de campo, revelou uma diferença de $25 \%$ entre essas duas análises.

No caso deste trabalho um experimento anterior ao da coluna igual ao realizado por Oliveira (1997) deu o resultado de $10 \mathrm{~cm}$ para espessura da franja capilar. Um cilindro de 10 $\mathrm{cm}$ de espessura foi preenchido com as micro-esferas de vidro. A saturação iniciou-se no extremo inferior, vedado por uma tela impenetrável para as esferas, até a altura de $5 \mathrm{~cm}$. Por capilaridade a água subiu até $10 \mathrm{~cm}$ no meio poroso. 
Nas colunas, após saturação e drenagem registrou-se uma franja capilar inicial de 10 $\mathrm{cm}$ na coluna $A$ e $11,5 \mathrm{~cm}$ na coluna $B$, e após equilíbrio das forças de gravidade e capilar a franja permaneceu com $12 \mathrm{~cm}$ e $13,5 \mathrm{~cm}$, nas colunas $A$ e $B$, respectivamente. Os dados reais se aproximaram do calculado pela Equação (3.3).

3.3 - Interação entre fluidos na franja capilar

A penetração da gasolina na franja capilar perturba o equilibrio entre os fluidos (água e ar) existentes no meio. Por causa da posição ocupada pela franja capilar, entre as zonas saturada e não saturada, a medida que a gasolina migra pela franja capilar forma um sistema de três fluidos (água/gasolina/ar), na região superior da franja, ou de dois fluidos (água/gasolina), na região inferior.

A relação de pressões é estabelecida com a pressão atmosférica ao nível d'água e pressão negativa na zona não saturada até o nível d'água.

A seguir mostraremos o comportamento da gasolina nas duas regiões.

\subsection{1 - Gasolina no Sistema Monofásico}

A "base" da franja capilar, antes da interação com a gasolina, representa um sistema de fluido único formado pela água subterrânea, onde a tensão superficial (retenção de água no solo) é a força que rege o meio. A Figura 3.8 apresenta a relação microscópica entre os fluidos na franja capilar antes a após a presença de gasolina.

O fluído unitário (a água) configura o equilíbrio por meio da manutenção das forças de coesão entre suas moléculas (força London-van der Waals de coesão do líquido atração entre as moléculas do fluido). Cada molécula possui uma área ao seu redor onde as forças (o vetor força) de ligação têm a mesma magnitude. Em contato com o meio sólido, as moléculas de água mais próximas ao sólido tendem a modificar a ação das forças intermoleculares para desenvolver forças de atração entre estas e o sólido e fortalecer a força de coesão (força London-van der Waals de adesão atração do fluido pelo sólido). A ação de outras forças ou a interferência de outro fluido abala o equilibrio entre as moléculas de água e entre estas e o sólido. 
a)

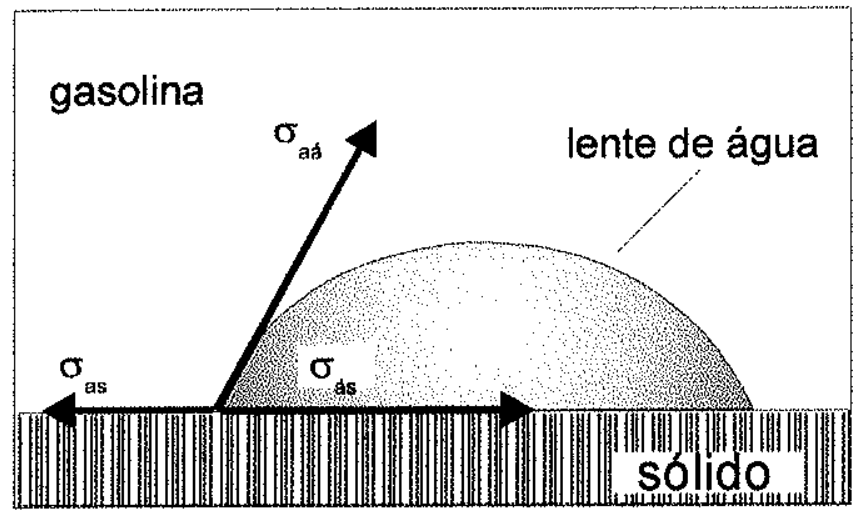

b)

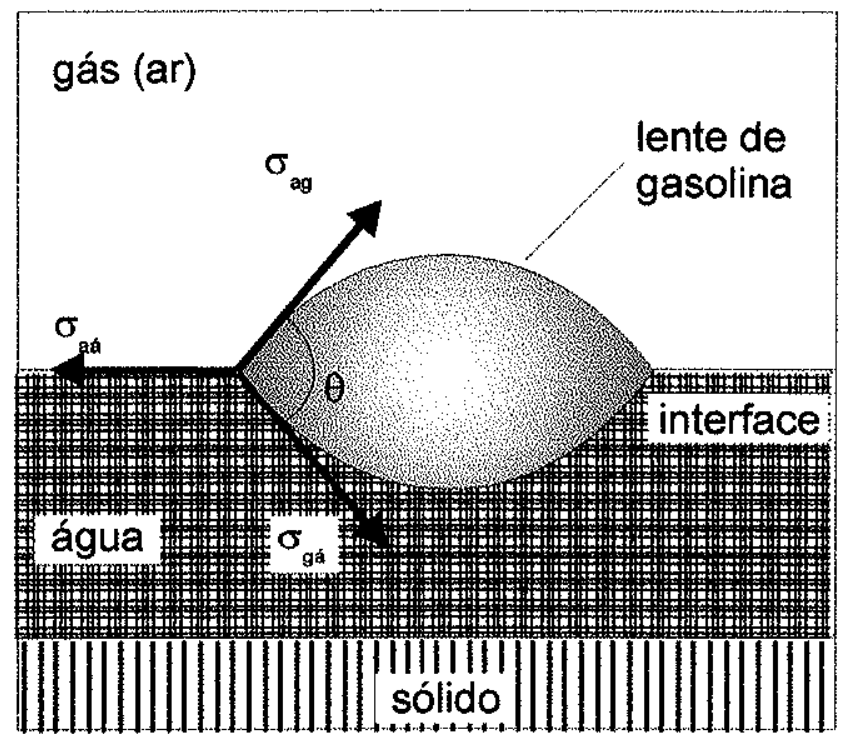

Figura 3.8 -a) tensões entre dois fluidos e o sólido, e b) tensões entre três fluidos e o sólido (Wilson,1992)

A ação das forças externas, agindo na esfera de influência da molécula de água, contrai a superfície do líquido minimizando a área. Isto leva ao desenvolvimento de uma energia potencial que se opõe a qualquer tentativa de distendê-la. Assim, caso ocorra uma distensão na membrana da área de influência a tendência da superfície é retornar a posição original (Fetter, 1992). A essa força de reação dá-se a denominação de tensão superficial.

Quando a gasolina penetra no solo desencadeia complexas reações, dentre estas aumento ou diminuição da condutividade aparente. A diminuição deve-se à redução de água devido ao seu deslocamento dinâmico. Em conseqüência da drenagem (expulsão da água nos poros pela gasolina) há redução da tensão superficial e alteração das propriedades molhantes. A penetração da gasolina reduz a conexão da fase aquosa entre os poros. A formação de bolsões de combustível comprime a franja capilar e reduz a porção água nesta zona (Williams,1996). Aumento da condutividade aparente ocorre quando a gasolina ou a mistura de gasolina/ar trocam com a fase vapor a condição de fluido não molhante, a redução da tensão superficial da água e redução no volume do anel pendular da água nos grãos de contato permitem a fase aquosa derramar-se e aumentar a conecção com outros poros que contenham água. 
A gasolina desconfigura o sistema de fluido unitário passando a integrar-se com a água. A tensão interfacial passa a reger a interface entre os dois fluidos, anteriormente regido pela tensão superficial apenas da água, Figura 3.8b. Em equilibrio as tensões:

$$
\sigma_{\text {água/ar }}=\sigma_{\text {água/gasolina. }} \cos \theta_{\text {água/gasolina }}+\sigma_{\text {ar/gasolina. }} \cos \theta_{\text {ar/gasolina }}
$$

$\mathrm{Se}$,

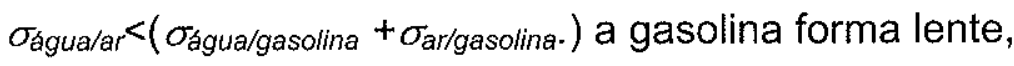

$\sigma_{a \text { agua/ar }}>\left(\sigma_{\text {águalgasolina }}+\sigma_{a r / g a s o l i n a}\right)$ não há equilibrio e a gasolina derrama sobre o ar e a água.

Segundo Willians (1992) todos esses efeitos podem ser alterados com o grau de saturação aquosa, química da água subterrânea, tamanho das partículas da matriz do solo, classificação dos grãos do solo, mineralogia da matriz do solo, porosidade (interconectada) efetiva, volatilidade da gasolina, difusão da gasolina, propriedades de dispersão e retardação, aditivos na gasolina, concentração da gasolina na fase aquosa e temperatura.

Da mesma forma como há tensão entre os dois fluidos, há tensão entre o fluido e o sólido. Por causa da ausência de mobilidade da superfície do sólido a interface com o fluido não obedece a equação de Laplace, (Defay e Prigogine, 1966).

Segundo Morrow et al (1970) a tensão superficial do fluido, n, é dada pela tensão da interface sólido-fluido, $\sigma_{S_{\alpha}}$, menos a tensão na superfície sólida quando este é envolvido pelo vácuo, $\sigma_{s}$.

$$
n_{s a}=\sigma_{s \alpha}-\sigma_{s}
$$

O modelo divide a tensão superficial na interface sólido-fluido, $\sigma_{s \alpha}$, em dois componentes, $n_{s \alpha}$ e $\sigma_{s}$. Quando o sistema está em equilíbrio o balanço de forças ao longo da tangente na superfície do sólido e normal a linha de contato das três fases (2 fluidos e 1 sólido) é dada por:

$$
\begin{aligned}
& n_{s \beta}+\sigma_{s}=n_{s \alpha}+\sigma_{s}+\sigma_{\alpha \beta} \cos \theta \\
& n_{s \beta}-n_{s i \alpha}=\sigma_{\alpha / \beta} \cos \theta
\end{aligned}
$$

os símbolos subescritos $\alpha$ e $\beta$ definem os dois fluidos envolvidos.

A Equação (3.6) remete à lei de Young para interação de dois fluidos,

$$
\sigma_{18} \cdot \cos \theta=\sigma_{s i}-\sigma_{s}
$$

própria para fluidos em contato com superficies lisas e planas. Uma vez que a superfície do sólido seja áspera a Equação (3.7) deve sofrer modificações ou correções de nivelamento, ou ainda tomar o ângulo aparente. 
A pressão desenvolvida na área saturada da franja capilar é dada por:

$$
P=P_{\text {amm }}+\rho \cdot g . z
$$

Onde:

$P_{a t m}$ é a pressão atmosférica

$\rho$ é a densidade da água

$g$ é a aceleração da gravidade

$z$ é a altura alcançada pela água

A diferença de pressão a ser mantida entre os dois fluidos nos poros para reter a saturação de um dos fluidos é definida como pressão capilar (Pc). Em equilíbrio estático (efeitos da gravidade desprezada), a Pc é relacionada a curvatura de cada menisco no poro (Larson et al, 1981).

$$
P C \equiv P_{n m}-P_{m}=\gamma J
$$

onde,

$P_{m m}$ é a pressão do fluido não molhante

$P_{u}$ é a pressão do fluido molhante

$\gamma$ é a tensão interfacial entre os dois fluidos

$J$ é duas vezes a curvatura principal

$$
J \equiv\left(\frac{1}{R}+\frac{1}{R^{\prime}}\right)
$$

onde,

$R \in R^{\prime}$ são os raios principais da curvatura. Para os efeitos da gravidade desprezados, $J$ é constante ao longo de toda interface.

Segundo Larson et al (1981) a configuração estática do menisco tem dependência descontínua na pressão capilar. Assim, uma mudança infinitesimal da Pc irá causar uma configuração não estável no menisco. A liberação brusca da energia capilar causa uma aceleração no menisco controlada somente pela pequena inércia relativa do fluido nos poros mais estreitos.

Larson et al (1981), continuam, a despeito da natureza dinâmica da invasão capilar pseudo-estática, depois de cada incremento de $\mathrm{Pc}$, o menisco deve rapidamente tomar a configuração estável. Assim as relações da PC são controladas por propriedades fluido/fluido/sólido estáticas, ou seja, tensão interfacial, molhabilidade, geometria do poro e topologia. 


\subsubsection{Gasolina no sistema plurifásico (2 fluidos)}

A superfície da franja capilar, antes da interação com a gasolina, é um sistema de dois fluidos formados pela água e o ar, onde a tensão interfacial $(\gamma)$ é responsável pelo equilibrio entre estas fases. As forças intermoleculares de cada fluido tomarão um arranjo diferente por influência da pressão interna do outro fluido.

Um exemplo cotidiano da existência da tensão interfacial são bolhas de sabão que diminuem de tamanho ao encontrarem uma força de oposição. O efeito da tensão interfacial é reduzir o tamanho da esfera por motivo da diferença entre as pressões internas e externas (Fetter, 1992).

O arranjo entre a água e o ar no sistema original dispõe as moléculas de água mais próximas ao sólido com maior aderência (força de coesão é a atração entre as moléculas de água) que as moléculas mais afastadas (adesão é definida pela atração entre estas e o sólido). Como estão ligadas, as moléculas marginais "puxam" as centrais formando o menisco.

A interface entre o ar e a água se encontra em equilíbrio somente quando a força resultante que atua nas moléculas do líquido for perpendicular a esta superfície. Se esta força tiver qualquer componente paralela à superfície, as moléculas se movem em resposta a essa componente e não haveria equilíbrio.

A gasolina vem alterar esta harmonia ao promover tensão interfacial entre 0 ar e a água, Figura 3.8b.

A quantidade de água deslocada dependerá dos parâmetros da gasolina e do solo, bem como a permeabilidade relativa do combustível e pressão capilar (Leverett and Lewis, 1940 in Willians, 1996).

Se no meio poroso não houvesse força capilar, haveria infiltração espontânea. Esta seria guiada por potencial mecânico, viscosidade e pressões internas de cada fluido envolvido. A Figura 3.9 mostra que a ausência de imbibição espontânea deve-se a variação da área de contato entre os fluidos ao longo do eixo capilar. Na Figura 3.9, o ângulo de contato na fase molhante torna a curvatura do menisco zero ou próximo de zero no capilar. Neste valor de curvatura do menisco, a sucção capilar torna-se nula e a imbibição deixa de existir. 


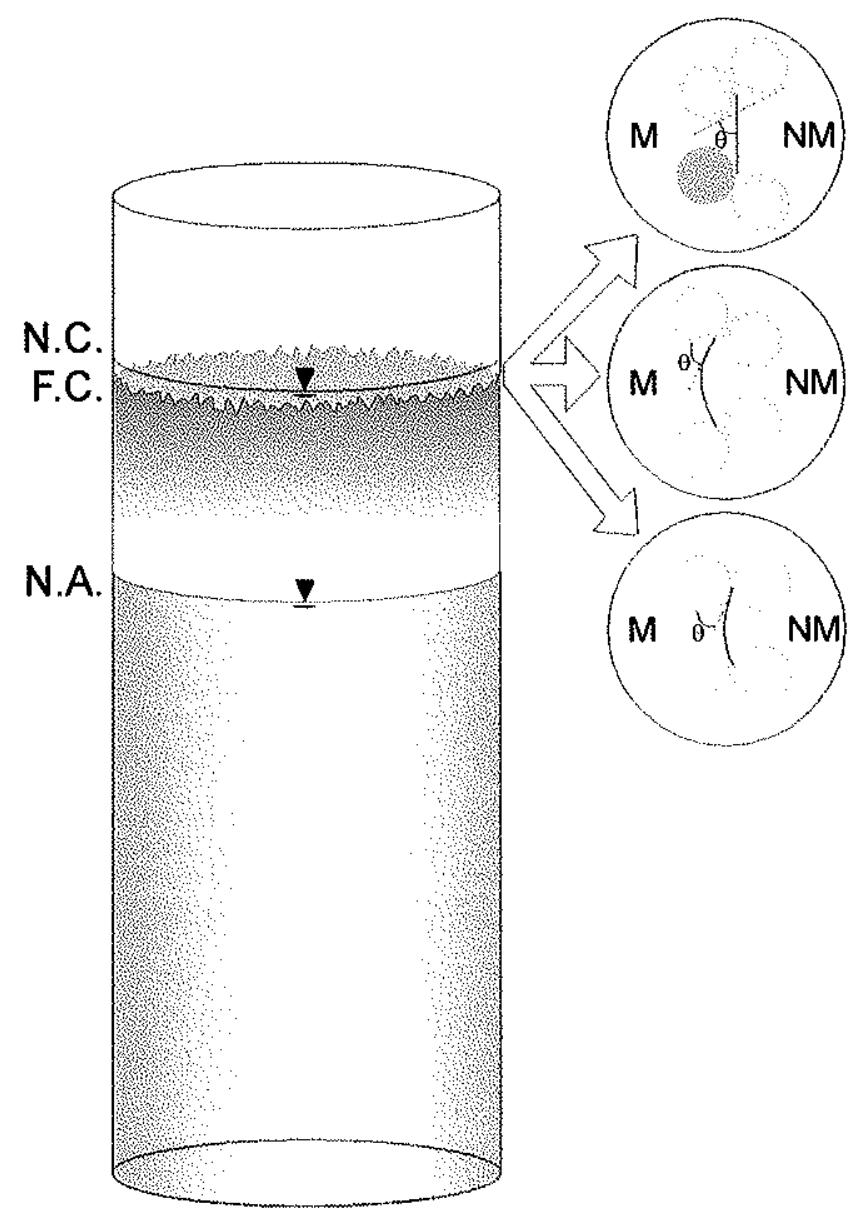

Figura 3.9 - Efeito da posição do menisco em poros de diferentes tamanhos (modificado de Dullien, 1992)

O equilíbrio mecânico é função de tensão interfacial. $O$ cálculo da pressão resultante da ação das duas forças é baseado nas pressões de cada fluido, pressão do molhante, pressão do não molhante.

Em cada ponto a tensão interfacial é perpendicular à linha de ação e tem o mesmo valor em toda direção da linha. Possui o mesmo valor em todos os pontos da superfície e tem a dimensão de força por unidade de comprimento, $\mathrm{N} / \mathrm{cm}$.

A equação de Laplace (condição de equilíbrio mecânico entre os fluidos) mostra que a tensão interfacial, na superfície arbitrária de raio principal de curvatura $r_{m}$, mantem o equilíbrio mecânico entre os dois fluidos de diferentes pressões. A pressão do lado côncavo é maior que a pressão do lado convexo. A Equação de Laplace mostra como calcula-se o valor da pressão gerada quando a superfície entre os fluidos torna-se curva. 
A pressão dos aros pendulares e glóbulos pendulares é determinado pela equação de Laplace de capilaridade que dá a diferença de pressão na interface entre dois fluidos imisciveis (Bear, 1979).

$$
\Delta \mathrm{P}=\frac{2 \gamma}{r}
$$

onde,

$\Delta \mathrm{P}$ é a diferença de pressão através da interface [atm]

$\gamma$ é a tensão interfacial $[F / L]$

$R$ é o raio principal da curvatura na interface $[L]$

$A$ análise da pressão capilar pode ser acompanhada por meio das forças que atuam no ponto $P$ de uma área elementar da interface entre dois fluidos imisciveis em equilíbrio, Figura 3.10. $\mathrm{Na}$ área curva há dois raios principais em dois planos ortogonais com ação de forças agindo em lados opostos:

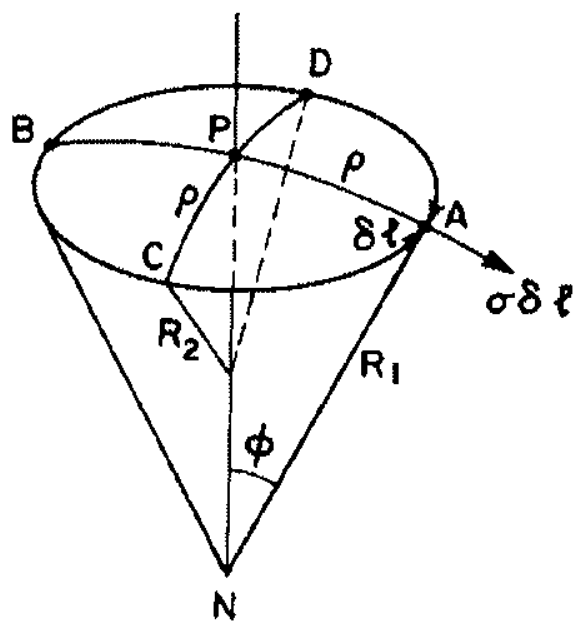

Figura 3.10 - Decomposição de tensões no ponto $P$ (Dullien, 1992)

Tem-se uma porção infinitesimal $A B C D$ de uma superfície convexa separando duas fases. Esta é caracterizada por dois raios principais de curvatura $A B=D C$ e $A D=B C$, raios R1 e R2, respectivamente. Em cada arco $(A B / D C / A D / B C)$ atua uma força $\sigma d l$ tangente a superfície e normal ao arco correspondente.

Estas forças:

1) Resultante das quatro forças:

$d F$ é a perpendicular a superfície, na direção do eixo $\mathrm{N}$. 
2) Resultante de duas forças de arcos paralelos:

$d F_{1}=\sigma d l_{2} \cdot \cos \gamma=2 \sigma d l_{2} \operatorname{sen} \theta_{1}$

Laplace relaciona a tensão interfacial e os raios de curvatura com a nova pressão devida a curvatura da interface.

$$
p=\sigma\left(\frac{1}{R_{1}}+\frac{1}{R_{2}}\right)
$$

1) Para uma superfície esférica: $R_{1}=R_{2}=r$

$$
p=\frac{2 \sigma}{r}
$$

2) Para uma superfície plana: $R_{1}=R_{2} \Rightarrow \infty$

$$
\begin{gathered}
p=0 \\
\Delta \mathrm{p}=\mathrm{PC}_{\mathrm{C}}=\mathrm{P}_{2}-\mathrm{P}_{1}=\sigma_{12}\left(\frac{1}{\mathrm{r}^{\prime}}+\frac{1}{\mathrm{r}^{\prime \prime}}\right)=\text { Equação }
\end{gathered}
$$

A pressão capilar é assim a medida da tendência do meio poroso de "sugar" o fluido molhante e repelir o não molhante.

Estas equações com referência a um ponto no poro são tomadas para fins estatísticos, dependem da geometria do poro, natureza dos sólidos e fluidos envolvidos (ângulo de contato) e grau de saturação (molhabilidade) que determina o volume do fluido nos pontos em contato dos grãos.

Como em condições reais o meio poroso possui uma trama bastante complicada, muitos modelos e expressões tentam correlacionar a pressão capilar no meio, fluidos e saturação com aproximação de um tubo capilar, Equação (3.11).

As considerações tornam-se mais complexas para o caso em que além da água, ar e gasolina também o etanol está presente no meio. Mesmo compondo uma fase única na mistura $E-24$, ao entrar no meio poroso o álcool particiona-se para a água e interfere nas relações de tensões e forças originais.

Na Figura 3.11 apresentada por Oliveira (1997), o etanol altera o volume da bolha de gasolina trapeada devido a redução da tensão interfacial. O etanol penetra pela garganta do meio poroso e reduz a tensão interfacial da bolha de gasolina na região do contato, Figura 3.11 b. A redução da tensão interfacial causa instabilidade capilar e leva a bolha de gasolina trapeada para direção do fluxo de etanol, Figura 3.11c. 

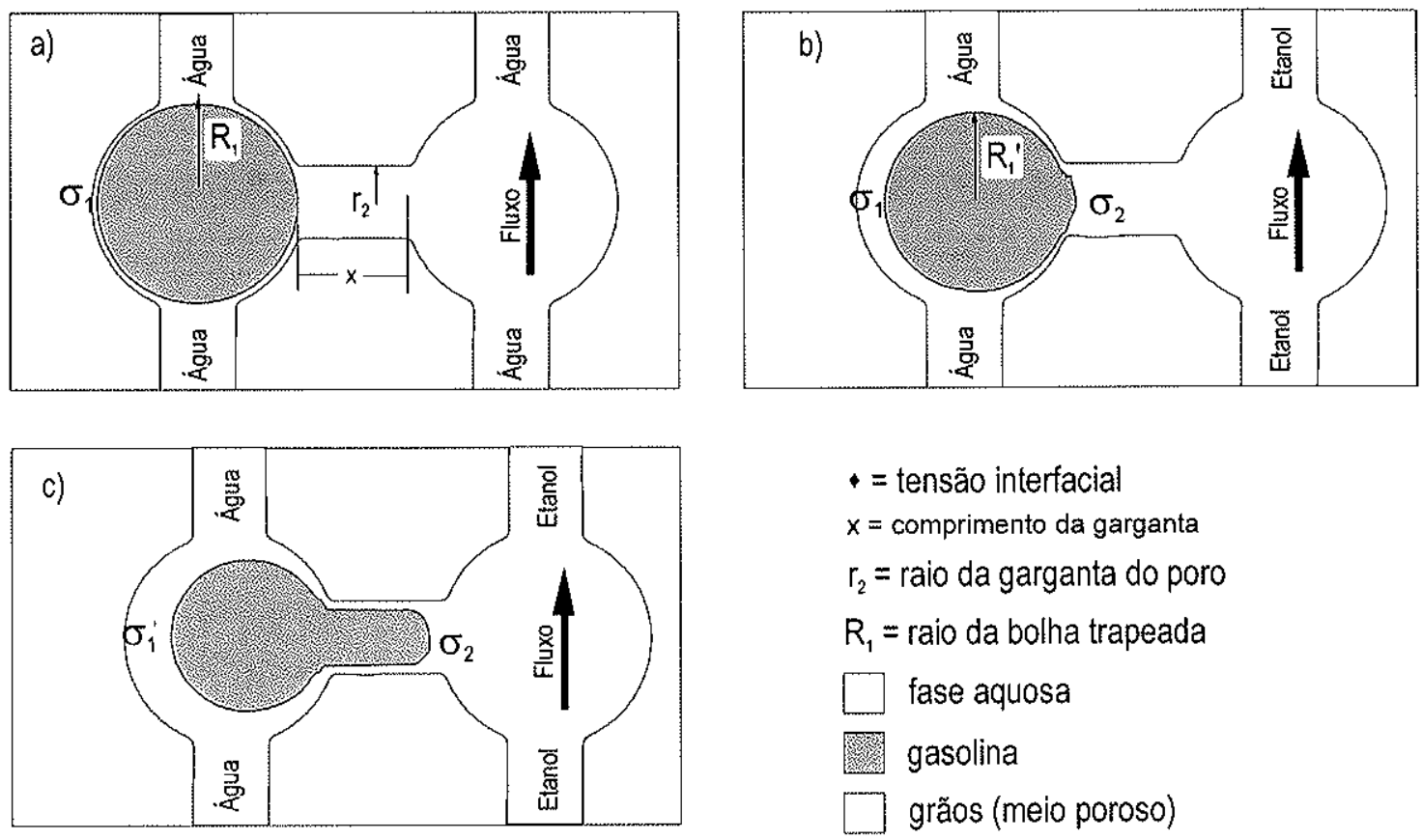

Figura 3.11 - Redução da tensão interfacial da gasollina (Oliveira, 1997)

Para o experimento aqui desenvolvido, o efeito da redução da tensão interfacial será similar, mesmo que o etanol não tenha sido injetado como substância única.

No experimento, o etanol presente na E-24 particiona-se para a água que envolve a bolha de combustivel. Esta migração provoca redução da tensão interfacial de toda superfície do E-24 e diminuição do volume da bolha, Figura 3.12.
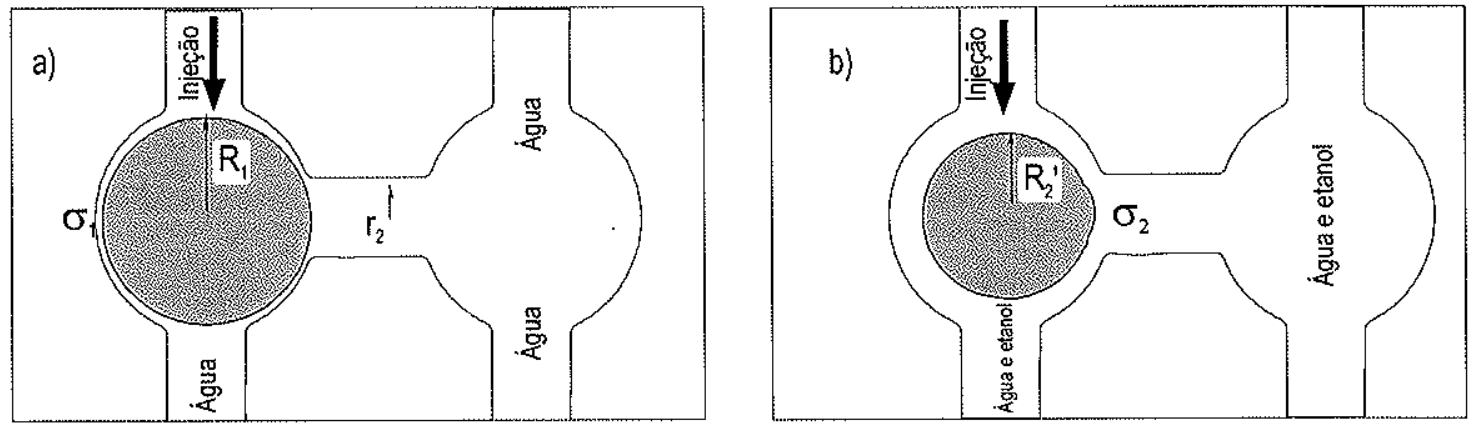

- = tensão interfacial

$R_{1}=$ raio da bolha trapeada

$r_{2}=$ raio da garganta do poro

$\square$ fase aquosa

$R_{2}=$ raio da bolha trapeada após migração do etanol para fase aquosa

E-24

$\square$ grãos (meio poroso)

Figura 3.12 - Redução da tensão interfacial da E-24 para o experimento. 
Na redução da tensão interfacial da E-24 há transferência de massa do combustível para a água. A massa de combustível transferida contem, além do etanol, os compostos mais solúveis da gasolina, BTEX (benzeno, tolueno, etilmbenzeno e os três isômeros do xileno). O grupo tem a solubilidade aumentada pela ação do etanol.

A tensão interfacial após transferência de massa, $\sigma_{2}$, representa a tensão interfacial mínima necessária para que a E-24 continue a migração pelos poros por ação de forças capilares. Isto porque a migração inicial foi induzida pela injeção do combustível sobre a franja capilar. O combustível estava sob ação da pressão de carga, gravidade e forças capilares com a tensão interfacial inicial da E-24, $\sigma_{1}$ no meio poroso.

As composições e volumes da E-24 e da fase aquosa modificam. A fase aquosa passa a conter compostos de gasolina e etanol. 
Capítulo 4

EXPERIMENTO

As duas colunas foram construídas segundo os mesmos passos de montagem, foram preenchidas por material de mesma composição e diâmetro e seguiram procedimentos idênticos de sedimentação. Estes últimos referindo-se a acomodação das micro-esferas de vidro de maneira a não formar camadas ou lentes, certificando um meio homogêneo e isotrópico. Os sistemas diferiram quanto ao combustivel injetado, a coluna $A$ recebeu gasolina pura e a coluna B, gasolina com adição de etanol a $24 \%$ (E-24).

Considerou-se as colunas prontas para injeção de gasolina após: instalação do poço de monitoramento, sedimentação das micro esferas, acondicionamento do conduto de injeção das gasolinas, saturação completa por água deionizada e deaerada (imbibição), drenagem, fixação do nivel d'água, a $53 \mathrm{~cm}$ para ambas colunas, e franja capilar, a $63 \mathrm{~cm}$ na coluna $A$ e $64,5 \mathrm{~cm}$ na coluna $B$. Entretanto estes valores não permaneceram constantes mesmo após cessar a recarga de água no sistema. O equilíbrio das forças gravitacional e capilar foi caracterizado pela estabilidade entre os níveis d'água e franja capilar, acompanhado macroscopicamente pela não variação destes niveis no período de 72 horas.

As novas medidas adquiridas com o equilíbrio entre as forças gravitacional e capilar estão na Tabela 4.1.

Tabela 4.1 - Medidas do nivel d'água e franja capilar, a contar da base da coluna

\begin{tabular}{|c|c|c|}
\hline & Coluna A & Coluna B \\
\hline Nível d'água & $58,6 \mathrm{~cm}$ & $62,3 \mathrm{~cm}$ \\
\hline Franja capilar & $64,4 \mathrm{~cm}$ & $67,8 \mathrm{~cm}$ \\
\hline
\end{tabular}

Após o equilibrio de forças, os combustiveis foram injetados diretamente sobre a franja capilar em ambas colunas. A aplicação de gasolina se deu através de um cilindro de 1 $\mathrm{cm}$ de diâmetro de $80 \mathrm{~cm}$ de comprimento ajustado a um funil contendo o combustível, Figura 4.1. O aparato foi desenvolvido para injetar gradualmente volumes conhecidos de gasolina.

O centro da coluna foi a área indicada a injeção da gasolina a fim de eliminar a influência do efeito de parede, que consistiria um caminho preferencial ao combustível devido a maior porosidade em relação a granulometria das esferas. Esta injeção foi contínua, pois 
conduzida em pulsos possibilitaria a formação de bolsões induzidos e consequentemente a descontinuidade da fase livre.
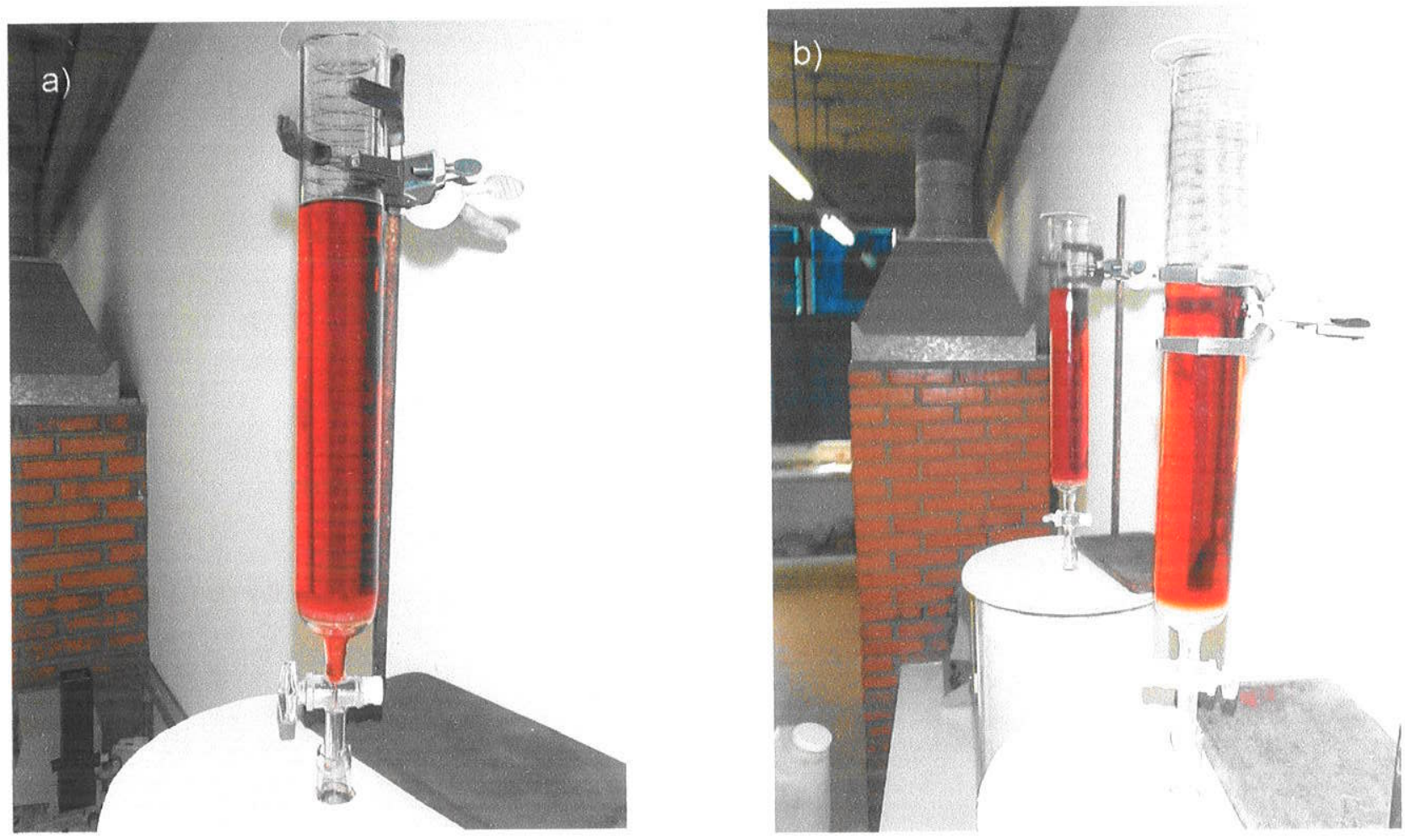

Figura 4.1 - Sistema de injeção de combustíveis, a) gasolina pura e, b) gasolina e E-24

\section{1 - Migração das Gasolinas}

$\mathrm{Em}$ aqüiferos, o transporte horizontal do soluto é feito pelo movimento da água subterrânea. Os processos físicos responsáveis por este transporte são advecção e dispersão hidrodinâmica. Outros processos operam como atenuantes e não como agentes de transporte (Freeze and Cherry,1979). O deslocamento vertical é função da condutividade hidráulica e anisotropia do meio. A descrição completa da migração em ambiente natural envolve forças da gravidade, capilares e perda de massa (química, biológica). Neste experimento validou-se a migração vertical somente na franja capilar até o alcance do nível d'água, no poço de monitoramento, e estimulou-se a componente horizontal na distância entre o ponto de injeção e o poço de monitoramento. As dimensões estimadas para as colunas foram favoráveis a este caminho de migração. $O$ tratamento biológico será aqui desprezado uma vez que a matriz utilizada como meio poroso não contém elementos 
orgânicos naturais. Da mesma forma, o tratamento à perda de massa devido as reações químicas entre os elementos do solo não será notada.

Os pontos de abordagem deste trabalho resumem se então, a fase livre formada pela gasolina sobre a franja capilar sob açãa de forças de gravidade e capilar. Segundo Oliveira (1995), as forças que agem na migração das gasolinas e água são função do tempo. Assim, há forças que influenciam no início, no final e durante (tempo moderado) o processo de migração. Ou ainda, forças atuantes no conjunto de dois períodos, moderado e final. Para validade da série de Philip (lei de infiltração, cuja Equação é derivada da Equação de Richards, Silveira et al, 1992) aplicada ao tempo inicial e moderado, o processo de infiltração é dominado por forças capilares sob efeito da gravidade. Essa ação capilar aumenta com o progresso da infiltração, no tempo final.

Os parâmetros de forças microscópicas são abordadas por Wilson (1992), onde a capilaridade é o resultado da interrelação de forças coesivas (dentro de cada fase fluida) e forças adesivas (entre o sólido e cada fluido). As forças viscosas ou dinâmicas de cada fase são proporcionais à permeabilidade média, permeabilidade relativa da fase fluida e ao gradiente de pressão da fase fluida. Estes fatores conduzirão o movimento do combustível.

Uma vez em subsuperfície a migração da gasolina é inicialmente controlada, segundo as leis de mecânica de fluidos, pelo potencial de fluido (mais alto potencial para o mais baixo) e suas propriedades físicas (tensão interfacial, densidade e viscosidade). Depois a gasolina migra vertical e lateralmente sob ação da gravidade efórças capilares na área porosa de umidade intermediária, ocupada por água e ar (Dullien,1992).

Na primeira área de contato das gasolinas na franja capilar já há outros dois fluidos: o ar e a água. Este encontro, aliado às propriedades da gasolina, faz irromper o fluxo polifásico da gasolina representado por:

1) infiltração através dos poros parcialmente saturados por água e ar,

2) deslocamento descendente vertical para a zona saturada, acompanhada através do poço de monitoramento.

3) dissolução parcial (componentes hidrofílicos) na água. No caso da E-24 esta partição é maior, pela propriedade co-solvente do etanol.

4) dissipação para a fase gasosa que ocorre a partir do vazamento. Na coluna B, segundo Oliveira (1997) há também formação de gás na variação de volume na mistura água/gasolina/etanol. 
$\mathrm{Na}$ trajetória descendente, a gasolina rompe a força capilar que retém a água de umidade, acumulando-se e tornando esta zona saturada de combustivel em fase livre (Fetter,1992). A água e o ar, por sua vez, em seu trajeto de saída dos poros podem ficar retidos nos capilares do meio poroso, Figura 4.2. Neste trapeamento há redução do espaço ocupado pela gasolina, fazendo o combustivel ocupar outros poros e favorecendo sua extensão lateral.

a) fluido não trapeado

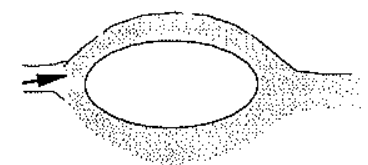

Estágio 1

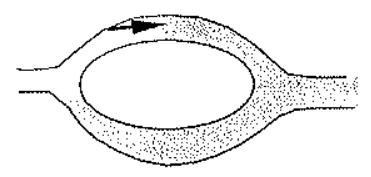

Estágio 2

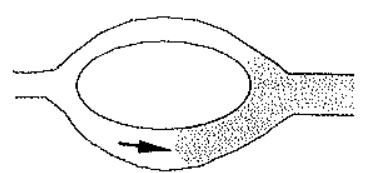

Estágio 3

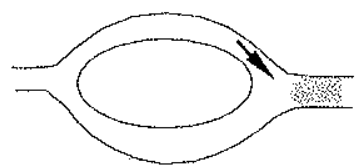

Estágio 4

b) trapeamento

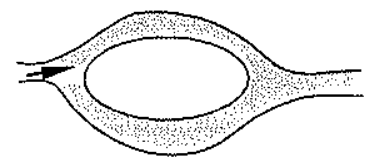

Estágio 1

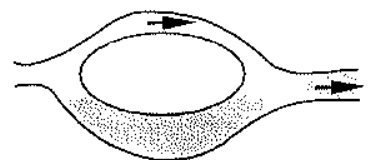

Estágio 2

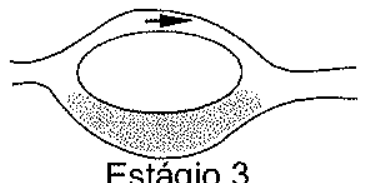

Estágio 3

Figura 4.2 - Trapeamento de água (Chatzis e Dullien, 1983)

No fluxo simultâneo, a fase molhante (água) envolve a fase não molhante (gasolina) que ocupa a região central do capilar. O aumento da saturação do fluido não molhante implica no avanço do diâmetro da configuração funicular, definindo o regime de fluxo funicular (Dullien, 1992).

Visto que a infiltração de gasolina no experimento é realizada sobre a franja capilar há tanto trapeamento de água quanto formação de configuração funicular. Isto em função da área de infiltração e acúmulo da gasolina. Quanto mais saturada de água e com grande variação de tamanho do poros, maior tendência ao trapeamento de água. Se a área tiver sedimentação uniforme facilita o fluxo funicular.

Como a franja capilar é uma região de granulometria homogênea, não proporciona a gasolina desvios alternativos que modifiquem sua trajetória, não existem camadas ou lentes de baixa permeabilidade para impedir o movimento descendente, ou ainda retenção do combustivel (Gillhan, 1984). Estas características fazem da franja capilar uma área de fluxo 
transiente de gasolina, onde há espaço (poros parcialmente ocupados por água e ar) para acúmulo de combustível sobre o nivel d'água.

Nas duas colunas montadas neste trabalho, os dois tipos de gasolina entraram no sistema na porção superior da franja capilar, mas a migração para o poço de monitoramento não ocorreu imediatamente. Na coluna $A$, somente após formação de $1,5 \mathrm{~cm}$ de fase livre sobre a franja, equivalente a injeção de $170 \mathrm{~mL}$ de gasolina pura, ocorreu o primeiro indício do combustível no poço de monitoramento (PM). Na coluna $\mathrm{B}$, o volume necessário para dar início a migração para o poço foi de $124 \mathrm{~mL}$.. As gasolinas migraram para o poço de monitoramento somente depois de formada uma parte da fase livre e não imediatamente após a injeção.

Nas duas colunas, após formação de fase livre iniciou se a migração de gasolina para o PM e, a partir de então prossegui-se o acúmulo simultâneo na franja capilar e no poço. Após a interrupção da fonte (depois de injetados $610 \mathrm{~mL}$ ) a migração da gasolina para o PM continuou.

Abdul et al (1989) explicam este fato associando o volume liberado à pressão de carga das gasolinas e forças capilares nos poros contendo previamente água (com potencial matricial negativo) e ar, ambos sob pressão negativa (menor que a atmosférica). A fração inicial de combustivel liberado apresenta baixa pressão de carga para penetrar nos PMs, cuja pressão na superfície da água é igual a zero. Visto que o fluxo se dá, em linha reta, em área de alto potencial para baixo potencial só haverá migração para o poço quando esta pressão de carga da gasolina superar a pressão do meio poroso.

Através das pesquisas de Marinelli e Durnford (1996) com diesel, sob gradiente hidráulico nulo, também pode-se explicar a presença de gasolina na zona não saturada (ou neste caso no "topo" da franja capilar) e ausência no poço de monitoramento. Marinelli e Durnford (1996) conduziram pesquisas através da comparação dos modelos de van Genuchten e Brooks-Corey, esta última confirmada o experimento aqui desenvolvido.

A Figura 4.3 mostra duas principais curvas de drenagem no sistema ar-água desenvolvidas para o mesmo padrão de solo. Brooks-Corey pregam que a pressão capilar deve exceder um valor finito, chamado de pressão de deslocamento, antes de haver drenagem. $O$ modelo de van Genuchten defende uma drenagem inicial para toda pressão capilar maior que zero. Transferindo estas colocações para os parâmetros empregados neste experimento e definindo duas constatntes em Marinelli e Durnford (1996) - onde $V_{0}$ (volume especifico de gasolina) é o volume total distribuído verticalmente dentro do perfil de solo por 
unidade planimétrica de área do aquífero e $\mathrm{T}_{\mathrm{w}}$ é a espessura de gasolina no poço de monitoramento - tem-se que devido a pressão de deslocamento, associada com o modelo de Brooks-Corey, a espessura de combustível no PM depende do trajeto. Como $V_{0}$ tem valor inicial zero, todas as pressões da gasolina no meio poroso são negativas, o que inibe a gasolina a entrar no poço e $T_{w}$ permanece em zero como mostra o segmento $a-b$ da Figura 4.4 .

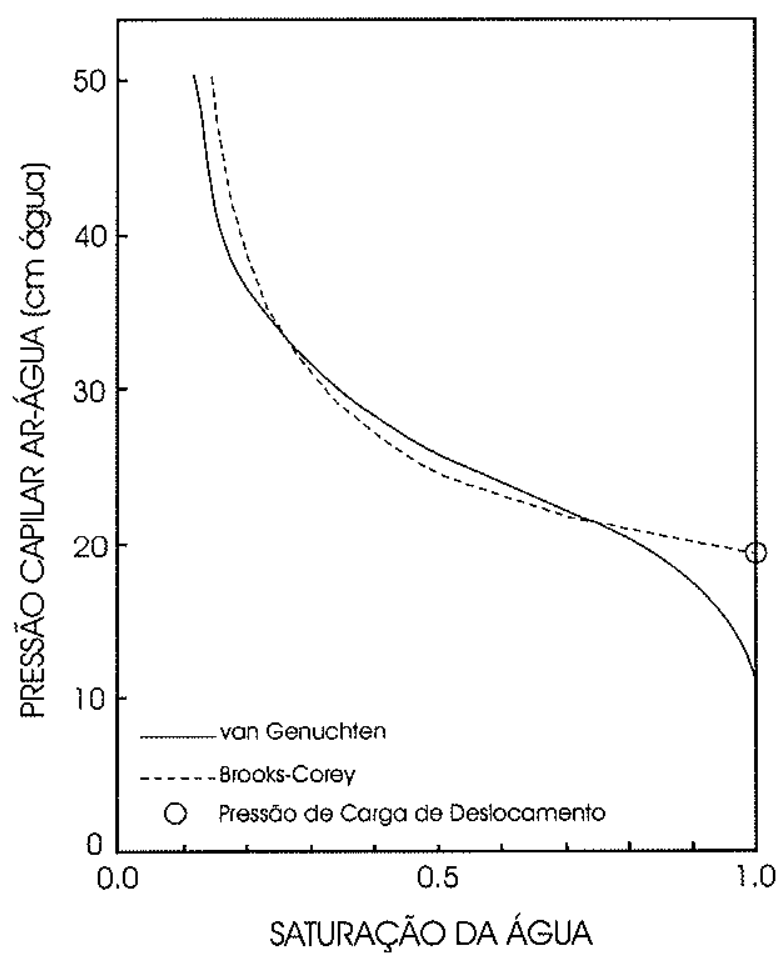

Figura 4.3 - Considerações de van Genuchten e Brooks-Corey para Pressão capilar x Saturação (Marinelli e Durnford,1996)

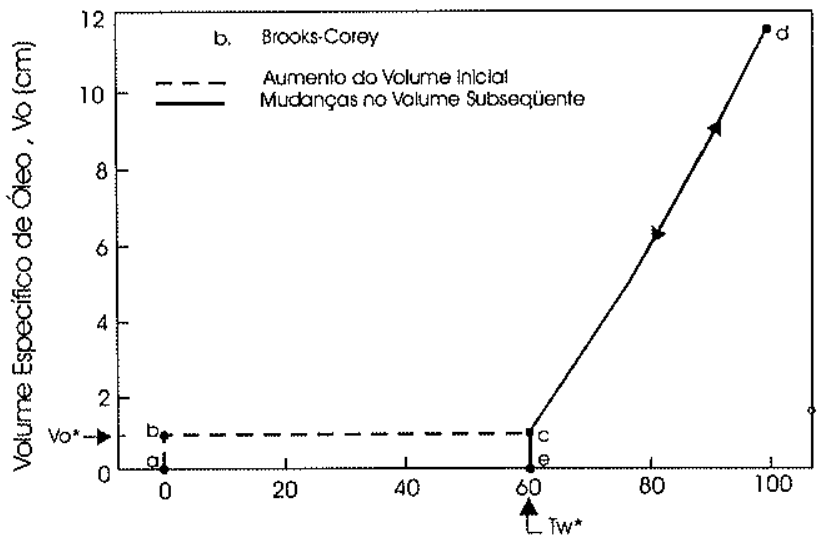

Espessura de LNAPL no Poço, Tw $(\mathrm{cm})$

Para um aumento de $V_{0}$ acima do volume específico crítico de gasolina, $V_{0}{ }^{*}, T_{w}$ alcançará instantaneamente a espessura da gasolina crítica $\left(\mathrm{T}_{\mathrm{w}}{ }^{*}\right)$, como indicado no ponto $\mathrm{C}$. No exemplo de Brooks-Corey, a espessura crítica de combustível é de $60 \mathrm{~cm}$, correspondendo a um volume especifico crítico de gasolina $\left(\mathrm{V}_{0}^{*}\right)$ igual a $1 \mathrm{~cm}$. Para aumentos subsequentes em $V_{0}, T_{w}$ aumenta linearmente. No caso de redução de $V_{0}, T_{w}$ segue a mesma trajetória, mas no sentido contrário, até a espessura crítica da gasolina $\mathrm{T}_{\mathrm{w}}{ }^{*}$. Contudo, se $V_{0}$ for reduzido ainda mais, $T_{w}$ permanece igual a $T_{w}{ }^{*}$, segmento c-e da Figura 4.4. Este comportamento ocorre porque a pressão da gasolina na interface água/gasolina no poço é igual à pressão da água nos poros no meio poroso, como mostra a Figura 4.5a, onde os pontos são medidas feitas com tensiômetros. Isto indica que a pressão exercida pela 
lâmina de gasolina no poço é balanceada pela pressão da coluna d'água no meio poroso contínuo.

Acima deste plano, as duas linhas de pressão (uma da água e outra da gasolina) divergem, sendo a $\mathrm{P}_{\text {gasolina }}$ sempre maior que a $\mathrm{P}_{\text {água }}$. A diferença máxima entre $\mathrm{P}_{\text {gasolina }} \mathrm{e}$ Págua é alcançada na elevação da interface no meio poroso. Esta é a pressão que a gasolina deve exceder, em relação a água, para deslocar a água nos poros saturados. A relação com as pressões do experimento podem ser acompanhadas na Figura 4.5b.

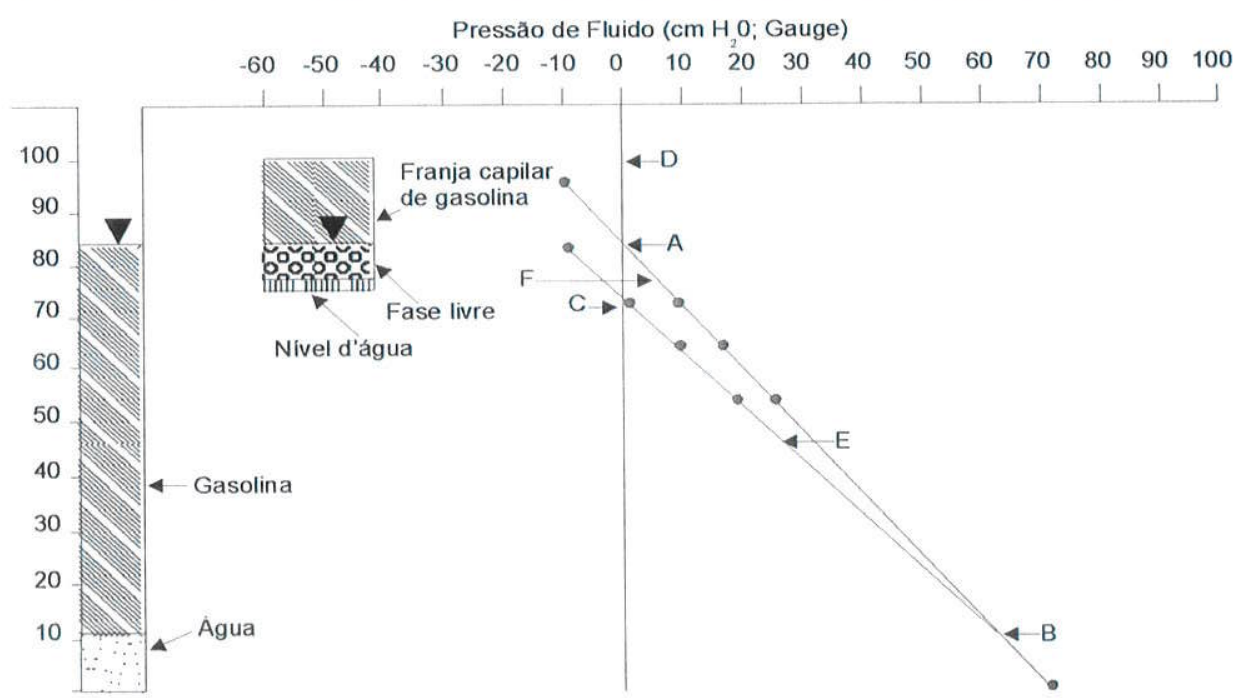

Figura 4.5a - Relações entre pressões no meio poroso e poço de monitoramento. Os pontos representam as medidas de tensiômetro (Abdul et al, 1989).
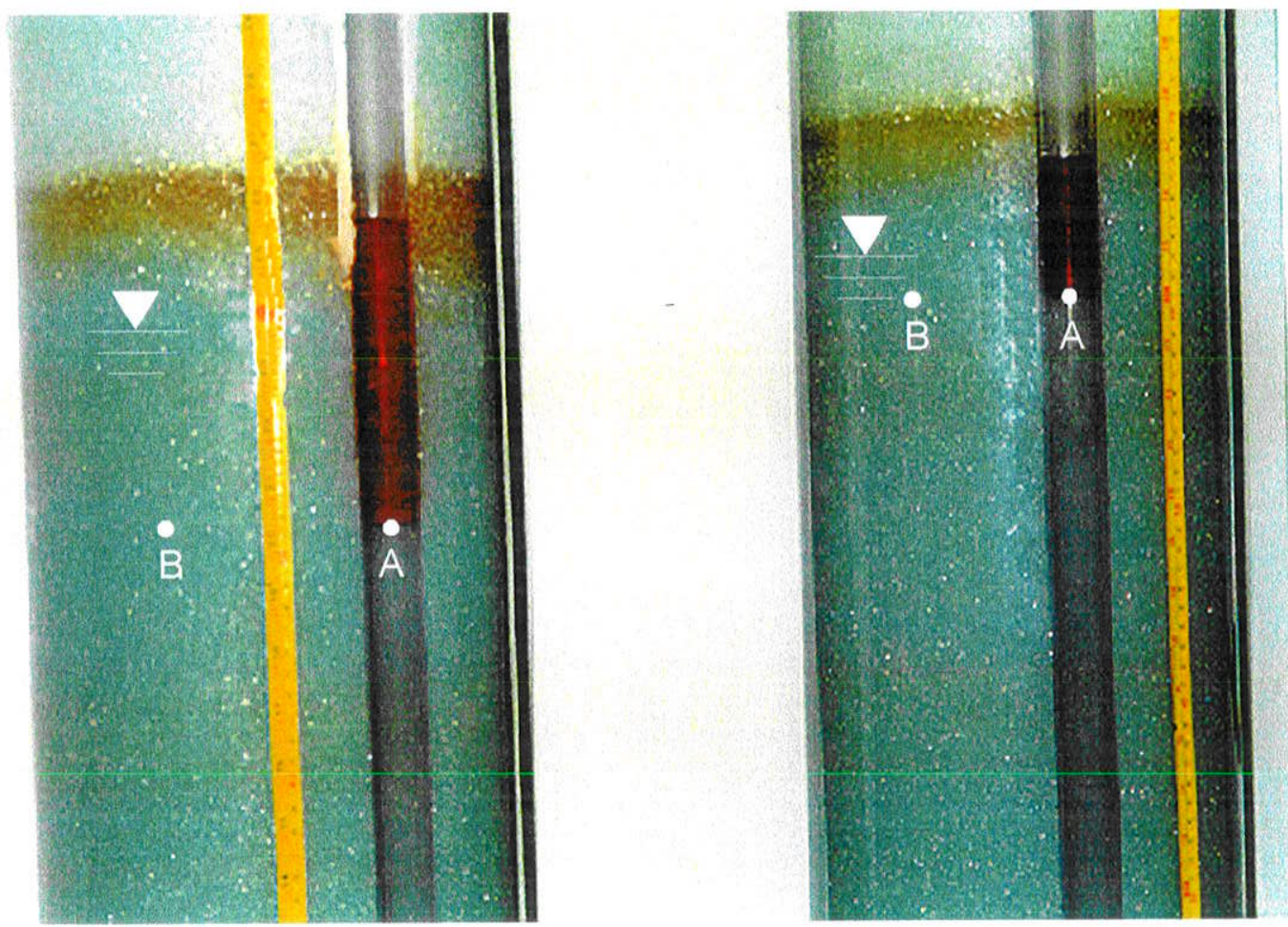

Figura 4.5b - Relação de pressões nas Colunas 
Os cálculos de Marinelli e Durnford (1996) indicam que a pressão da gasolina no PM não é alta o suficiente para permitir que o combustível invada o meio saturado por água na posição imediatamente adjacente ao poço. Isto implica que a pressão capilar gasolina/água não excede a pressão de deslocamento gasolina/água associada. Como resultado, o modelo de Brooks-Corey, na visão de Marinelli e Durnford (1996), prevê que a gasolina no poço torna-se hidraulicamente desconexa da gasolina no meio poroso na altura da espessura da gasolina, no $\mathrm{PM}$, igual a $\mathrm{T}_{\mathrm{w}}{ }^{*}$. Uma vez que a quantidade de gasolina exceda $\mathrm{V}_{0}{ }^{*}$, o modelo de Brooks-Corey prevê que a relação $T_{w}$ versus $V_{0}$ será a linha sólida d-e da Figura 4.4.

No experimento das colunas, o volume de combustíveis injetado, $610 \mathrm{~mL}$, foi proporcional à pressão induzida na água e no ar presentes na franja capilar. A interface formada entre os três fluidos resulta em um gradiente de tensões, e a medida que a pressão do combustivel aumenta mais água é expulsa dos poros. Quando a $P_{\text {gasolina }}$ torna se maior que a $P_{\text {àgua }}$ o combustível flui para o poço. Como a pressão da gasolina foi aumentanda com sua injeção progressiva, o excesso foi jogado para o PM. No poço, onde havia a interface ar/água formou-se a interface ar/gasolina/água.

A invasão espontânea dos poros pelo fluido molhante é a manifestação das mesmas forças capilares que causam elevação capilar do líquido molhante deslocando o ar em tubos de pequenos diâmetros. A elevação, $h$, no tubo cilíndrico de raio capilar $r$, é dado pela expressão, já apresentada no Capítulo 2:

$$
h=\frac{2 \cdot \gamma \cdot \cos \theta}{\Delta \rho \cdot g \cdot r}
$$

A Equação (4.1) representa também a pressão de deslocamento, $P_{d}$, que é vista como a pressão de combustível necessária para penetrar no meio saturado.

$$
\begin{aligned}
\mathrm{P}_{\mathrm{d}}=\mathrm{h} \rho \mathrm{hm} \mathrm{g}-\mathrm{h} \rho_{\mathrm{m}} \mathrm{g} & \mathrm{P}_{\mathrm{d}}=2 \gamma \cos \frac{\theta}{\mathrm{r}} \\
h=\frac{2 \cdot \gamma \cdot \cos \theta}{\Delta \rho \cdot g \cdot r} &
\end{aligned}
$$

onde,

$\rho_{n m}$ e $\rho_{m}$ são as densidades do fluido não molhante e do fluido molhante $(\mathrm{g} / \mathrm{mL})$

$h$ é a altura da água subterrânea $(\mathrm{m})$

$g$ é a aceleração de gravidade $\left(\mathrm{m} / \mathrm{s}^{2}\right)$ 
Oliveira (1997) e Wilson (1992) mostram, com seqüência de fotos, o trajeto da gasolina no meio poroso. Nestas ilustrações é possível notar o derramamento do combustível sobre a forma insular da água, Figura 4.6.
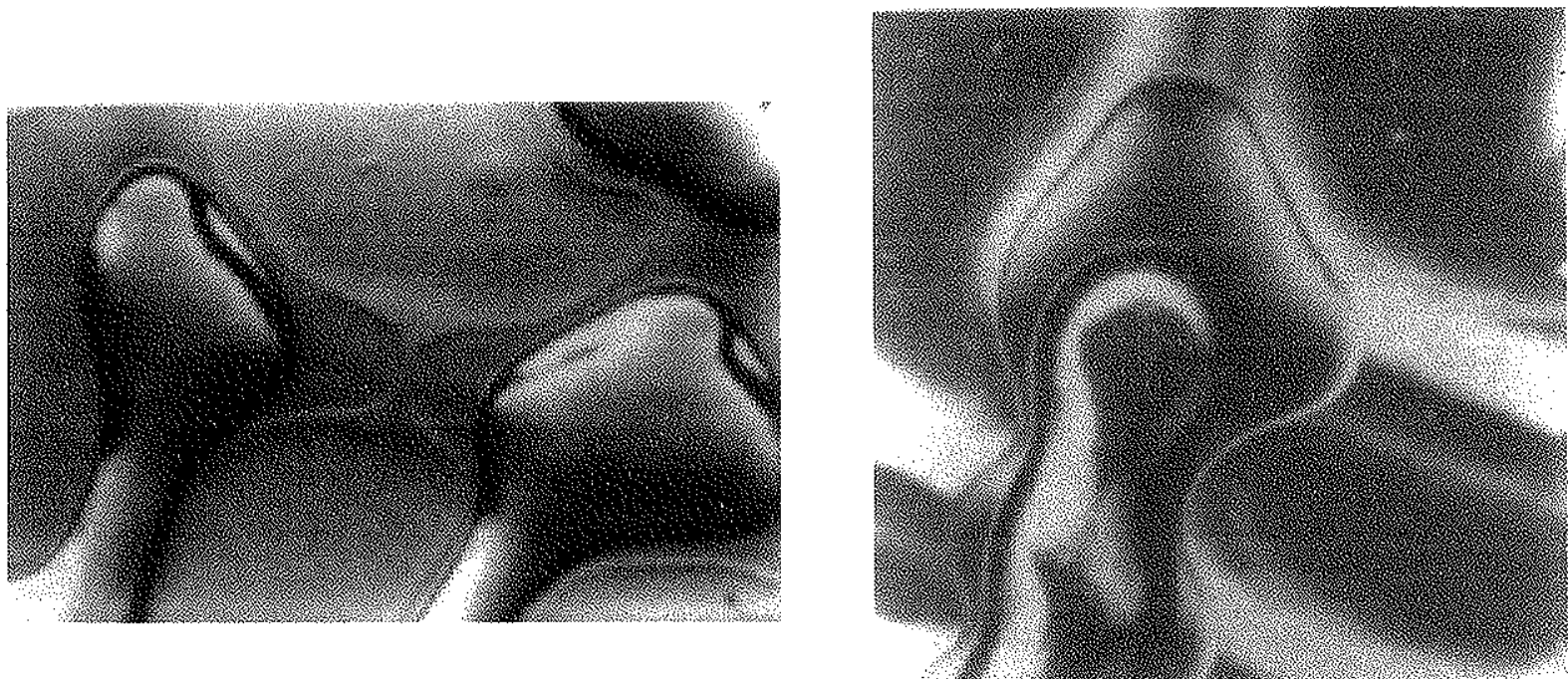

Figura 4.6 - Detalhe do equilíbrio da gasolina no meio poroso depois de infiltrado no meio (Wilson, 1992)

De maneira similar a descrita no processo de drenagem da água pelo ar, no Capítulo 2, a gasolina penetra nos poros maiores expulsando a água que pode ficar trapeada. Wilson (1992) explica que muitos compostos orgânicos têm força de coesão fraca (a gasolina, por exemplo) e ao derramarem-se penetram nos poros de baixa pressão. Desta maneira ao empurrarem a água para poros menores, sob alta pressão capilar, esta fica submetida à força de sucção. A fração de água retida nos poros sob sucção representa a fase aquosa irredutivel.

A sucessão de fotos das Figuras 4.7 e 4.8 mostra a fase livre parcialmente formada no meio, começando a migrar para o PM. A Figura 4.7 mostra o comportamento da gasolina pura e a Figura 4.8 da E-24. Nas Figuras 4.7a e 4.8a, a fase livre está parcialmente formada e a gasolina inicia sua infiltração no poço, até então não havia qualquer indício de gasolina no PM. Nas Figuras 4.7b-d e 4.8b-d, a adição contínua de combustível levou ao aumento simultâneo da lâmina no PM e no meio. No poço, a interface gasolina/ar elevou-se e o nível d'água apresentou decréscimo progressivo. Na Figura 4.7e e 4.8e, a espessura da camada de combustivel aumenta e o NA no meio elevou-se como resultado da redução de espessura da franja capilar (Abdul et al, 1989). Em cada estágio do experimento o aumento da espessura de gasolina no poço é balanceado pelo aumento do nível d'água. 

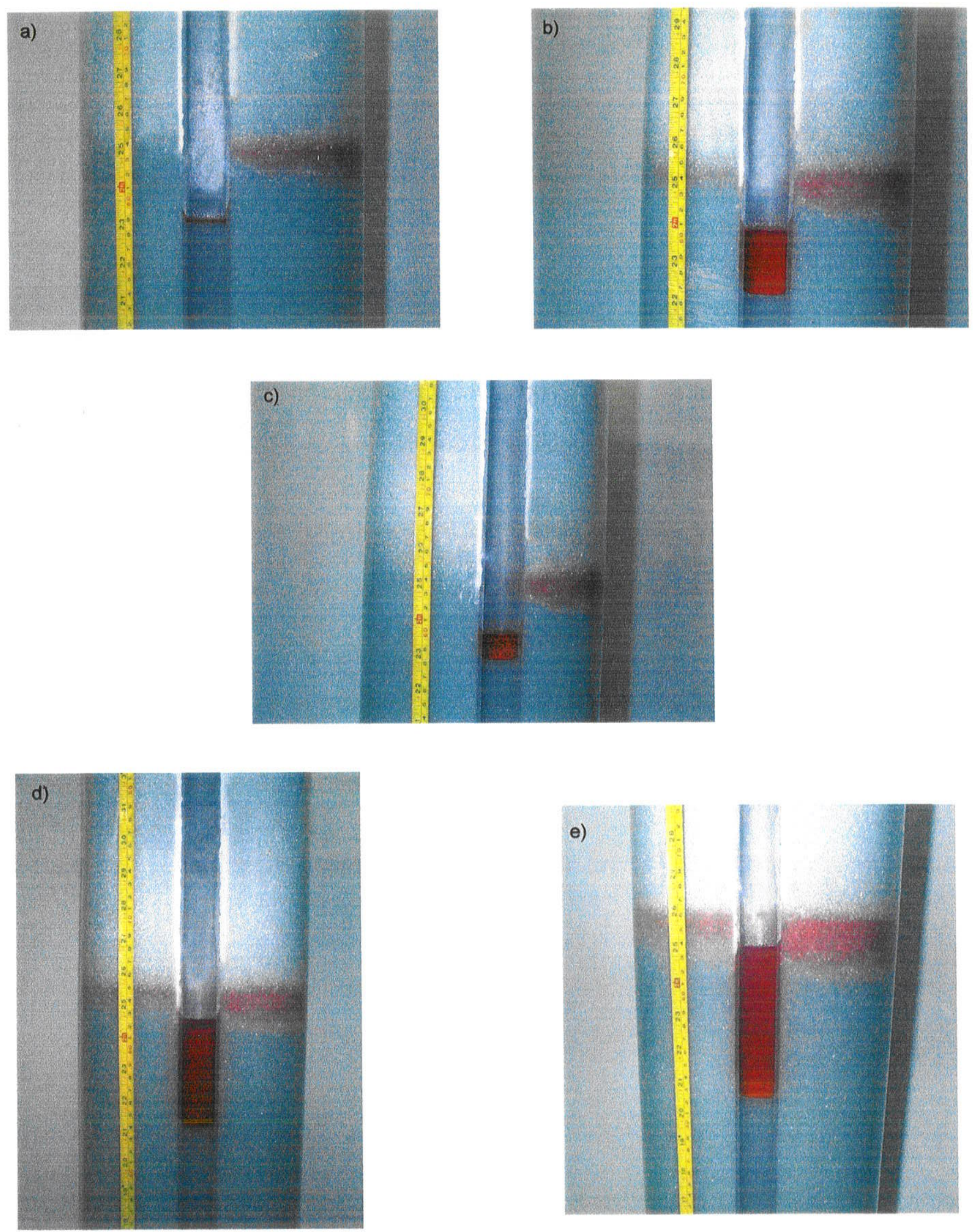

Figura 4.7 - Seqüência de infiltração da gasolina pura 

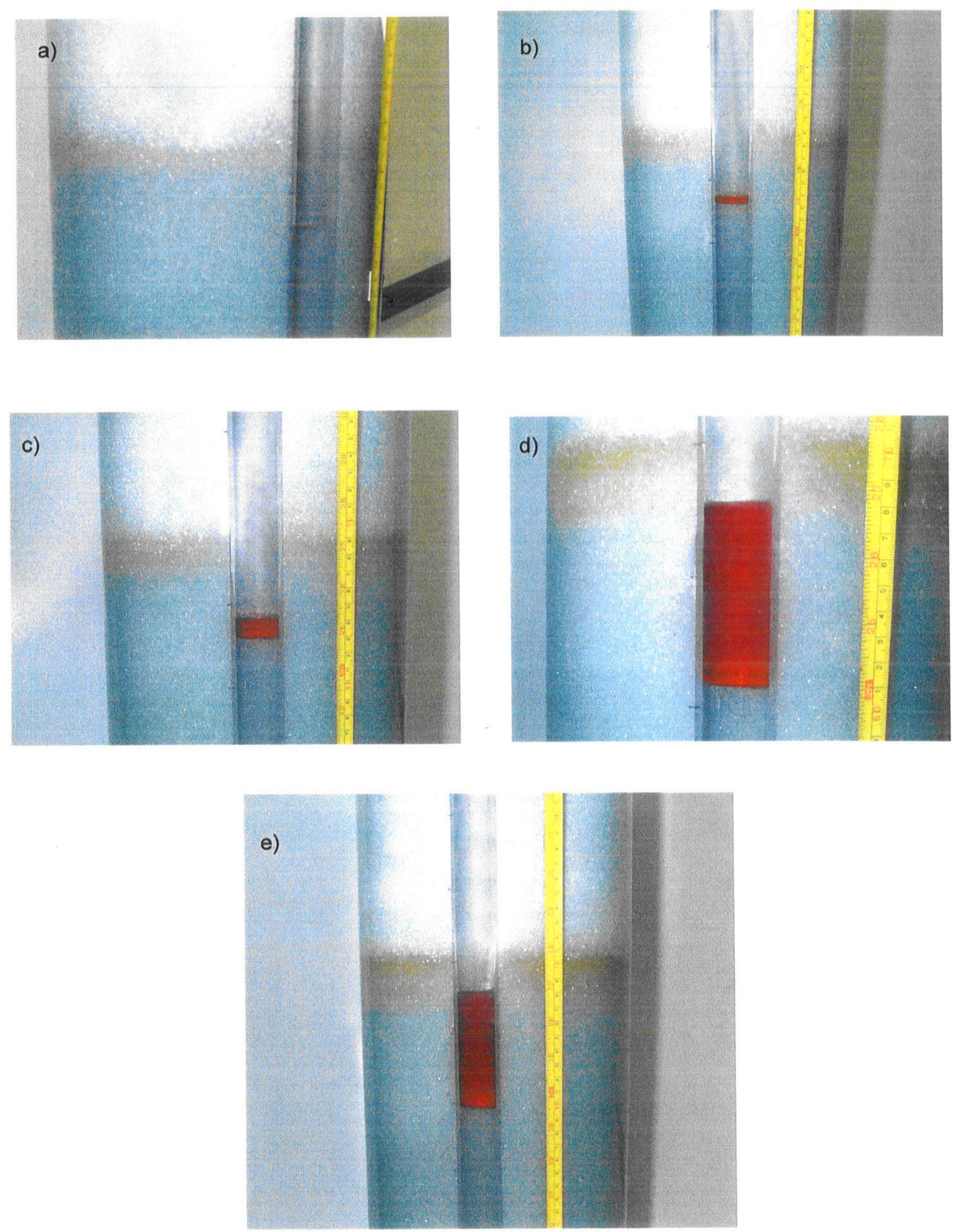

Figura 4.8 - Formação da fase livre da E-24. 
O cessar da migração e a consequente formação 'final' de fase livre sobre a franja capilar seria assim resumida:

1) antes da injeção da gasolina a água de umidade está sob pressão negativa;

2) a gasolina inicia a interação com o meio com pressão mais baixa (mais negativa) que a da água. No entanto, a pressão aumenta (torna-se menos negativa) com o tempo;

3) quando pressão de carga de gasolina supera a pressão de água, a gasolina penetra no poço de monitoramento. Quando o conteúdo de gasolina excede seu valor de saturação residual e a soma da saturação da água e saturação da gasolina é igual a $100 \%$ configura pressões positivas nos poros. Nesta zona a gasolina será móvel e migrará para o PM, Fetter (1992).

4) todo o volume de gasolina que representa o excesso sobre a pressão d'água migra para o PM. A condição de $\mathrm{P}_{\text {gasolina }}=\mathrm{P}_{\text {água }}$ no meio, retorna, implicando no cessar do fluxo.

O volume de gasolina que flui para o poço representa a fração superior à pressão da água. $O$ equilíbrio seria caracterizado pela ausência de fluxo, ou seja, $P_{\text {gasolina }}=P_{\text {água }}$.

A gasolina acumulada sobre a franja capilar reduz a espessura original da franja. A gasolina ocupa o espaço do ar nos poros e empurra a água para direção da zona saturada. No poço de monitoramento, a lâmina de gasolina rebaixa o nível d'água. Este rebaixamento é proporcional a espessura da lâmina de gasolina que vai se acumulando. A nova posição do nível d'água no PM é de $46,6 \mathrm{~cm}$ para coluna A (gasolina pura) e $51 \mathrm{~cm}$ na coluna $B$ (E-24), Figura $4.5 b$.

A molhabilidade heterogênea, referida no Capítulo 3 , pode ser observada na área da franja capilar não totalmente ocupada pela gasolina. $O$ mesmo ocorre na região imediatamente superior a franja, da mesma forma contendo parcialmente gasolina pura ou $E$ 24.

As duas colunas foram monitoradas e fotografadas até a migração da gasolina para o poço cessar (cerca de 45 dias). O tempo de migração e espessuras das gasolinas foram medidas e comparadas para as duas colunas.

Com fase livre formada, uma série de condições distintas foram observadas nas duas colunas. O comportamento da gasolina pura na franja capilar difere da interação do E-24 devido a relação das duas misturas com o fluxo de água e os componentes miscíveis dos dois combustíveis. A presença de etanol no E-24 desencadeia a série de diferenças na configuração final do experimento. 
As espessuras de gasolina pura formadas no poço de monitoramento e meio poroso foram maiores que as respectivas espessuras formadas pela E-24.

O experimento vem mostrar que os dados de campo, medidos nos PMs, não fornecem estimativa precisa quanto a quantidade de combustiveis em subsuperfície. Como mostrado na Figura 4.9, as lâminas de gasolina formadas no PM possuem maior espessura que a sua continuidade no solo.

$\mathrm{Na}$ Coluna $\mathrm{A}$, de gasolina pura, formou-se uma lâmina de $15,6 \mathrm{~cm}$ no PM e $6 \mathrm{~cm}$ de fase livre na franja capilar. Para a Coluna $B$, de E-24, esses valores foram de $12 \mathrm{~cm}$ de lâmina no PM e $3 \mathrm{~cm}$ de fase livre sobre a franja, Figura 4.9.

$\mathrm{Na}$ Coluna $\mathrm{A}$, apesar das precauções tomadas no preenchimento das colunas em favor da homogeneidade do meio (seleção das esferas na fração de $850 \mu \mathrm{m}$ e sedimentação sem formação de camadas) observou-se no período de disposição da gasolina sobre a franja capilar que a fase livre nos laterais do PM não tinham a mesma espessura no decorrer da migração. No entanto após 5 (cinco) dias os dois lados nivelaram-se e o estágio anterior de não interferiu na formação final da fase livre, Figura $4.7 \mathrm{~b}$ e c.

Dakin et al (1992) aplicaram os dados obtidos com derramamento de xileno e demonstraram o cálculo da espessura verdadeira (T) estimada pela divisão da espessura aparente medida no poço de monitoramento $\left(h_{w}+h_{1}\right)$ pela constante $(C)$, com os valores frequentemente variando de 4 a 6 dependendo da densidade do hidrocarboneto, Figura 4.10. Para LNAPLs o fator utilizado é o 4.

$$
\begin{aligned}
& T=\left(h_{w}+h_{f}\right) / 4, \text { ou } \\
& T=4\left(h_{c}+h_{f}\right)
\end{aligned}
$$

onde,

$\mathrm{h}_{\mathrm{w}}$ é espessura da lâmina de gasolina no poço

$h_{f}$ é espessura da fase livre no meio poroso

$h_{c}$ é espessura da franja capilar da gasolina

Os valores para o cálculo para espessura da fase livre a partir da Equação 4.2, são:

- para coluna $A$, gasolina pura: $T=15,6 / 4 \Rightarrow T=3,9 \mathrm{~cm}$

- para coluna $B, E-24: T=12 / 4 \Rightarrow T=3 \mathrm{~cm}$ 


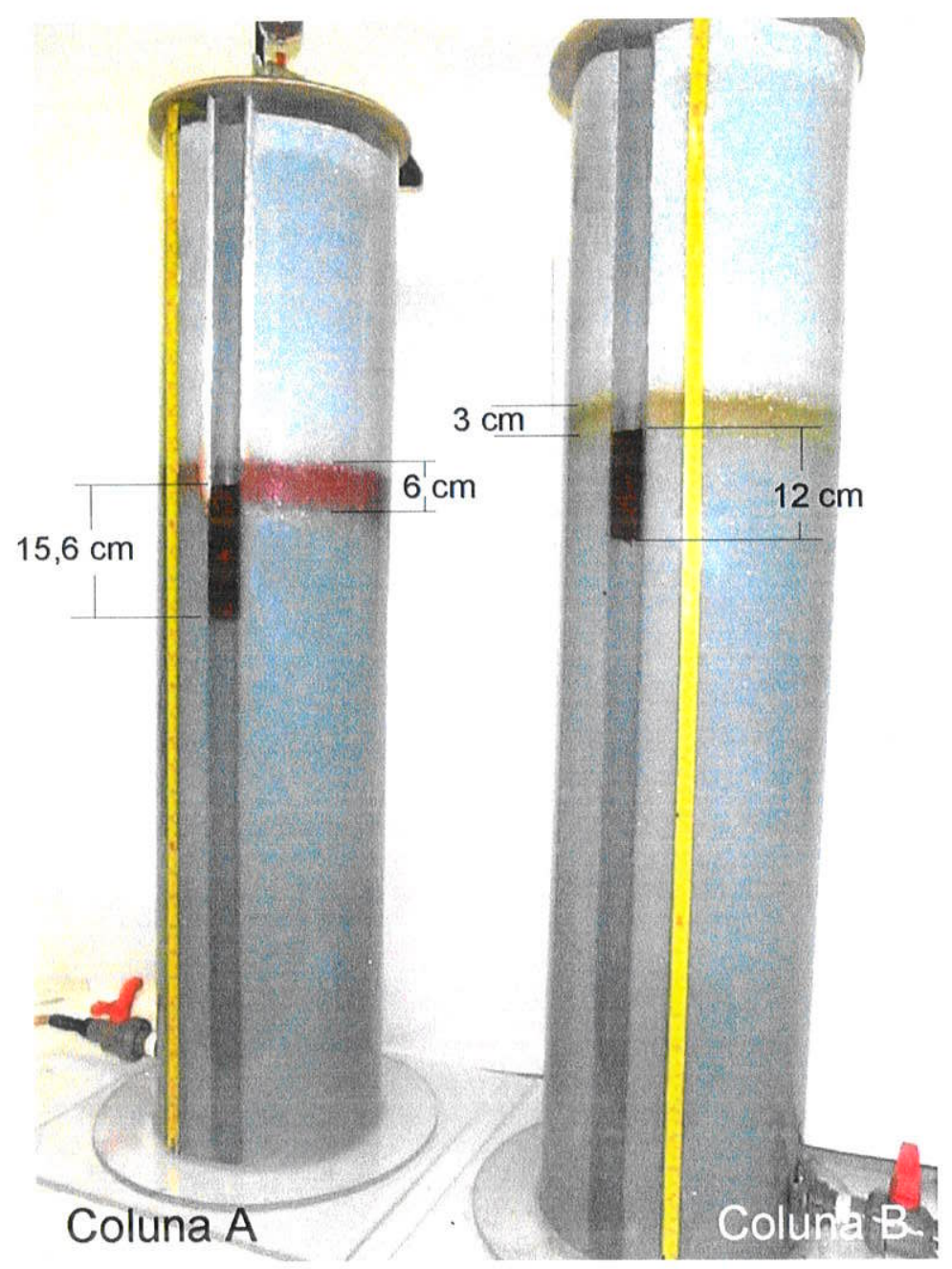

Figura 4.9 - Diferenças de espessuras entre a Coluna A e da Coluna B.

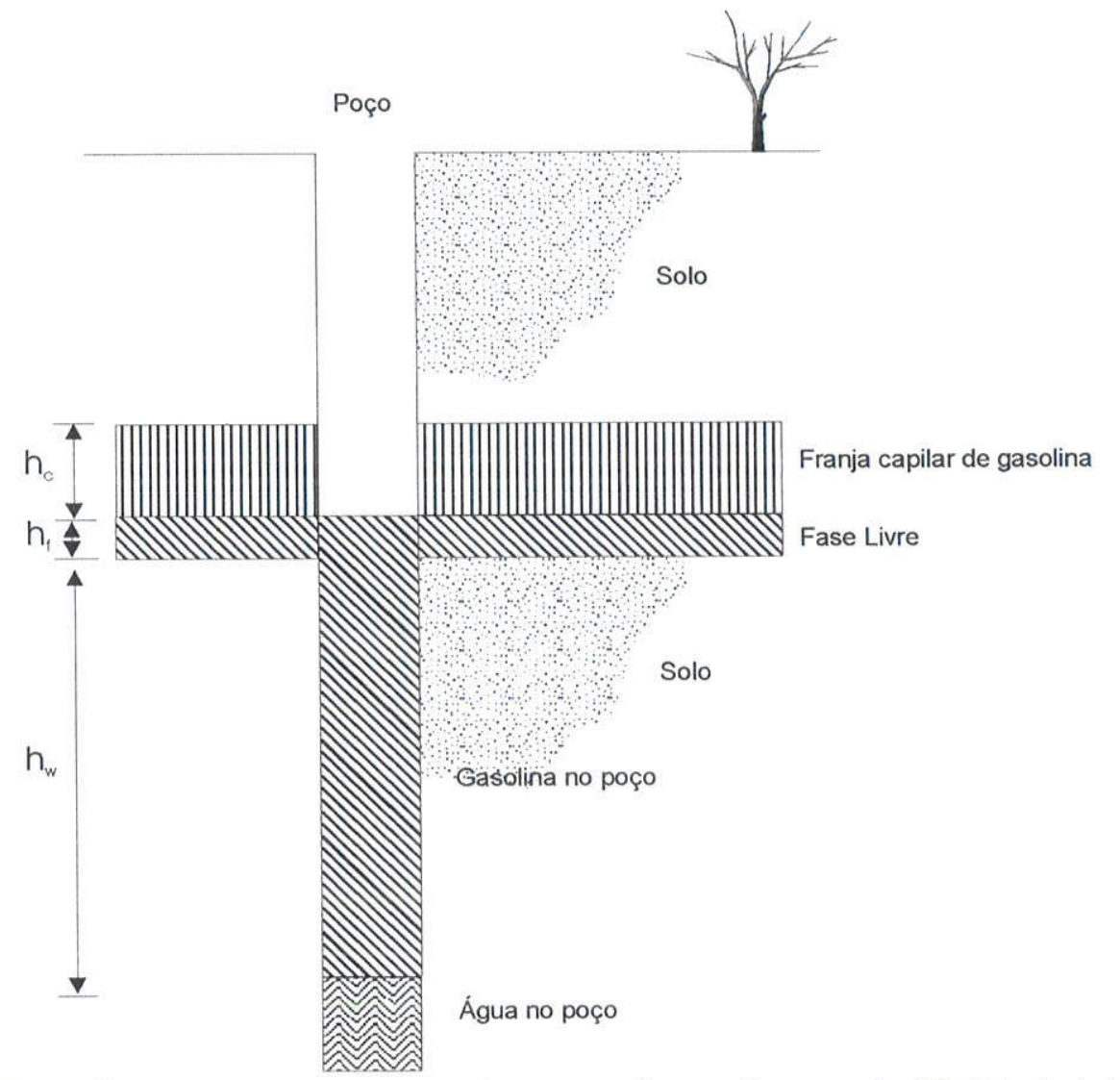

Figura 4.10 - Relações de espessuras no meio e poço de monitoramento (Abdul et al, 1989) 
No decorrer da migração houve diferenças nas velocidades das gasolinas na formação da fase livre.

A coluna B iniciou o acúmulo de E-24 na franja capilar antes da formação da fase livre de gasolina pura. Mas apesar desta diferença inicial as lâminas de gasolina pura, na coluna A, formaram-se antes das lâminas da E-24.

A velocidade inicial de migração da gasolina é função de:

- Volume derramado

- Densidade do combustível, Oliveira (1997) mostra a diferença e os cálculos para medir a variação das densidades após mistura dos três fluidos água/gasolina/etanol.

- Porosidade do meio

- Forças de viscosidade e capilaridade.

O fluxo de dois ou mais fases fluidas concorrendo no espaço poroso é observada pela Lei de Darcy.

A velocidade "final" da gasolina varia com:

1) velocidade do fluxo da água subterrânea

2) volume do vazamento e continuidade (se pontual ou fonte contínua)

3) condutividade hidráulica do aquífero (que difere da zona não saturada)

A zona não saturada é composta de partículas sólidas que formam poros completos por ar e água em frações aliadas ao tipo de material. Também como no meio saturado a velocidade de fluxo é regida pela lei de Darcy:

A umidade e condutividade hidráulica não saturada são funções do potencial de matriz do solo, que varia com a hidrofilia do material do solo e distribuição do tamanho dos poros.

Após fase livre formada, houve migração ascendente de gasolina para a zona não saturada, Figura 4.11:

Após concluída a injeção do combustível e o equilíbrio das forças capilares terem sido parcialmente atingidos, notou-se uma migração de combustível da fase livre para zona não saturada. Notou-se um maior volume na coluna B.

Em termos de equilibrio, a coluna A mostrou estabilidade entre a lâmina de gasolina pura no PM e a fase livre no meio em 3 dias. Neste período a coluna $B$ ainda apresentava variação de espessuras. O equilíbrio da E-24 foi atingido após 30 dias. Para fins comparativos desprezou-se, neste item, esta migração contínua para o poço de monitoramento. 
Na Coluna B, a migração ascendente da E-24, com o tempo, aconteceu antes e simultaneamente à formação da fase livre.
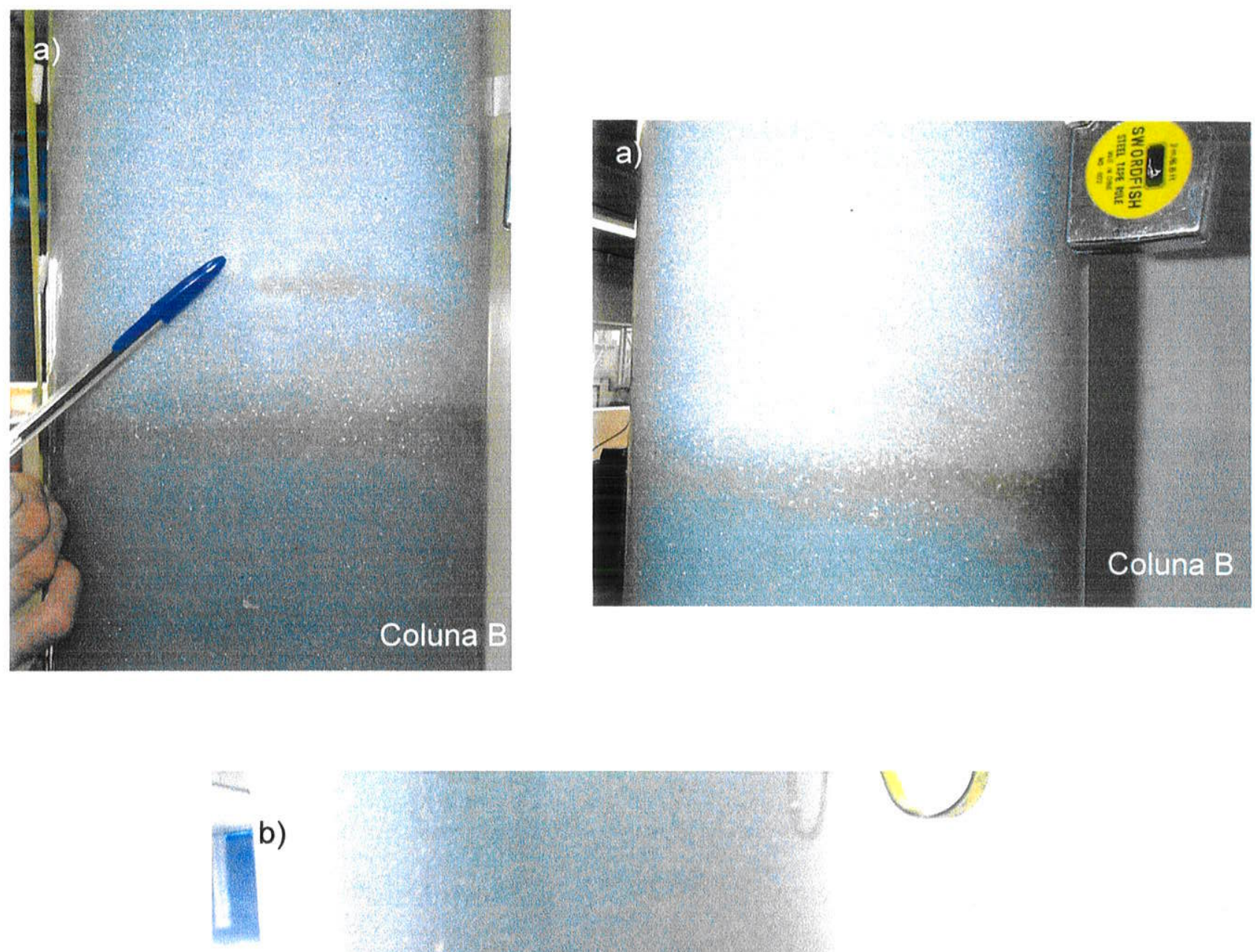

b)

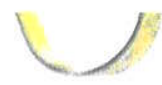

Coluna A

Figura 4.11 - Ascensão de combustível, a) simultâneo à formação da fase livre, b) após formação da fase livre. 


\section{A fase livre da E-24 na franja capilar mostrou uma elevação em torno do poço de} monitoramento.

Na Coluna B, como pode-se acompanhar na Figura 4.12, mostra um comportamento não horizontal da fase livre após 14 dias do experimento. A lâmina de E-24 no meio poroso apresentou uma elevação próxima ao poço de monitoramento. A medida que a pluma se distancia do PM tende a horizontalidade.

Esta configuração é característica do período pós formação da fase livre, durante a acomodação da E-24 sobre a franja capilar a pluma permaneceu horizontalizada ao longo de toda superfície.

Os níveis de combustível (NC) e níveis d'água (NA) não obedeceram o mesmo patamar nas duas colunas.

Para Coluna A, o topo da lâmina gasolina pura no poço de monitoramento nivelou-se em $3,9 \mathrm{~cm}$, a contar do topo da franja capilar. A base da lâmina (nível gasolina/água) baixou aproximadamente $12 \mathrm{~cm}$. O mesmo não aconteceu com o $\mathrm{E}-24$, onde o nível ar/gasolina na coluna B ficou $3 \mathrm{~cm}$ abaixo do topo da franja capilar, Figura 4.13. Mesmo descontando a elevação próxima ao PM descrita no item anterior, a posição do nível de E-24 no PM está abaixo $1 \mathrm{~cm}$ do nível inferior da fase livre no meio poroso.

Oliveira (1997) demonstrou a maneira de estimar-se, com dados do PM, a posição do nivel d'água antes da injeção da gasolina. Com base neste procedimento seguiu-se 0 exemplo de Oliveira (1997). A Figura 4.13 mostra a gasolina pura e a E-24 no estágio final do experimento, onde o equilíbrio já está mantido e a interface de contato está bem caracterizada. Tem-se que a pressão do ponto $A$ é igual a pressão no ponto $B$, derivando no balanço igual a:

$$
\begin{gathered}
\rho_{\mathrm{a}} \cdot \mathrm{g} \cdot \mathrm{h}_{\mathfrak{a}}=\rho_{\mathrm{g}} \cdot \mathrm{g} \cdot \mathrm{h}_{\mathrm{g}} \\
h_{\mathrm{g}}=\frac{\rho_{\mathrm{a}}}{\rho_{\mathrm{g}}} h_{\dot{a}}
\end{gathered}
$$

onde,

$\rho a=$ densidade da água $(\mathrm{g} / \mathrm{mL})$

$\rho_{\mathrm{g}}=$ densidade da gasolina $(\mathrm{g} / \mathrm{mL})$

há = altura da água na coluna (m)

$h_{g}=$ altura da gasolina na coluna $(m)$ 
$\mathrm{g}=$ gravidade $\left(\mathrm{ms}^{-2}\right)$

Para os valores de $\rho_{\theta}=0,996 \mathrm{~g} / \mathrm{mL}$ e $\rho_{g}=0,736 \mathrm{~g} / \mathrm{mL}$ para gasolina pura e $0,724 \mathrm{~g} / \mathrm{mL}$ para E-24, tem-se:

$$
\begin{aligned}
& h_{g}=1,35 h_{a} \\
& h_{g}=1,38 h_{a}
\end{aligned}
$$

para gasolina pura e para $\mathrm{E}-24$

Diante estes valores estima-se que $74,07 \%$ de lâmina de gasolina pura permanecerá abaixo do nivel d'água (medida do NA anterior ao vazamento) e 25,93\% estará acima do NA. Para a E-24, 72,46\% é o valor abaixo do NA e $27,54 \%$ corresponde a lâmina acima do NA.

Transportando estes valores para os dados visuais do experimento tem-se que na coluna A $76,92 \%$ é a taxa de gasolina pura abaixo do padrão de NA anterior ao vazamento e $23,08 \%$ o índice de combustivel acumulado acima do NA. Para a coluna B os valores reais são de $95,83 \%$ e $4,17 \%$ correspondente a fração de E-24 abaixo e acima do NA respectivamente.

Ainda seguindo os procedimentos de Oliveira (1997), mas transferindo os parâmetros para o problema da localização do nível d'água para a gasolina injetada, tem-se considerações e aliando a Equação (4.5):

$$
h_{N A}=h_{e}-0,275 h_{g}
$$

para o cálculo referente da posição do $N A$, onde $h_{N A}$ é a altura do nível d'água segundo um datum (que pode ser a base do PM), $h_{e}$ é a medida do topo da camada de combustível e $h_{g}$ é a espessura da zona contaminada, Oliveira (1997). Estes cálculos somente são possíveis mediante valor das densidades.

Quanto a determinação da posição do topo da fase livre tem-se os cálculos baseados na determinação da franja capilar, Capitulo 2. A partir do valor da profundidade do NA através do poço de monitoramento e da litologia do aqüifero tem se a estimativa da posição da franja capilar a consequentemente a profundidade de acúmulo do combustível em subsuperfície. 


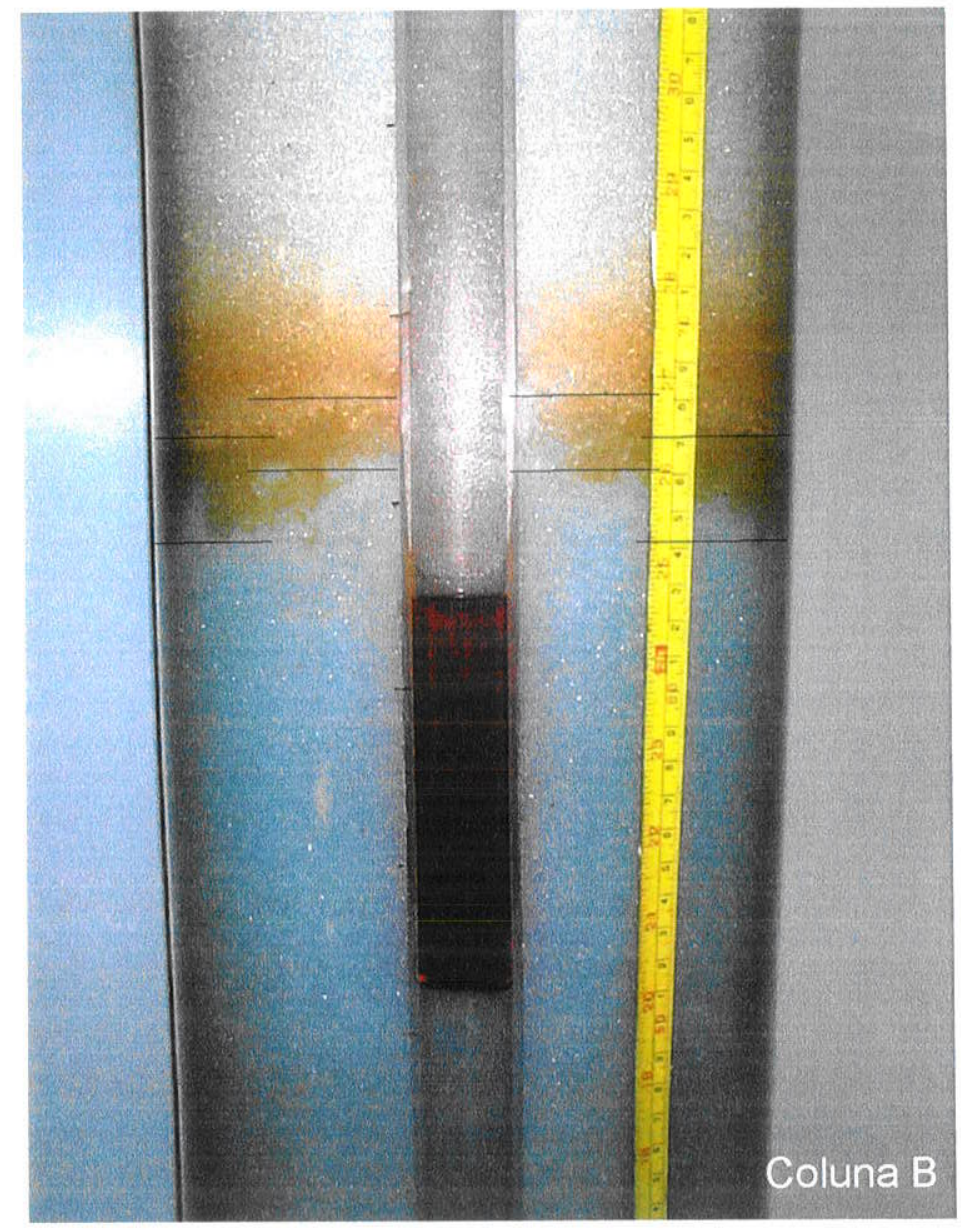

Figura 4.12 - Elevação da fase livre ao redor do poço de monitoramento
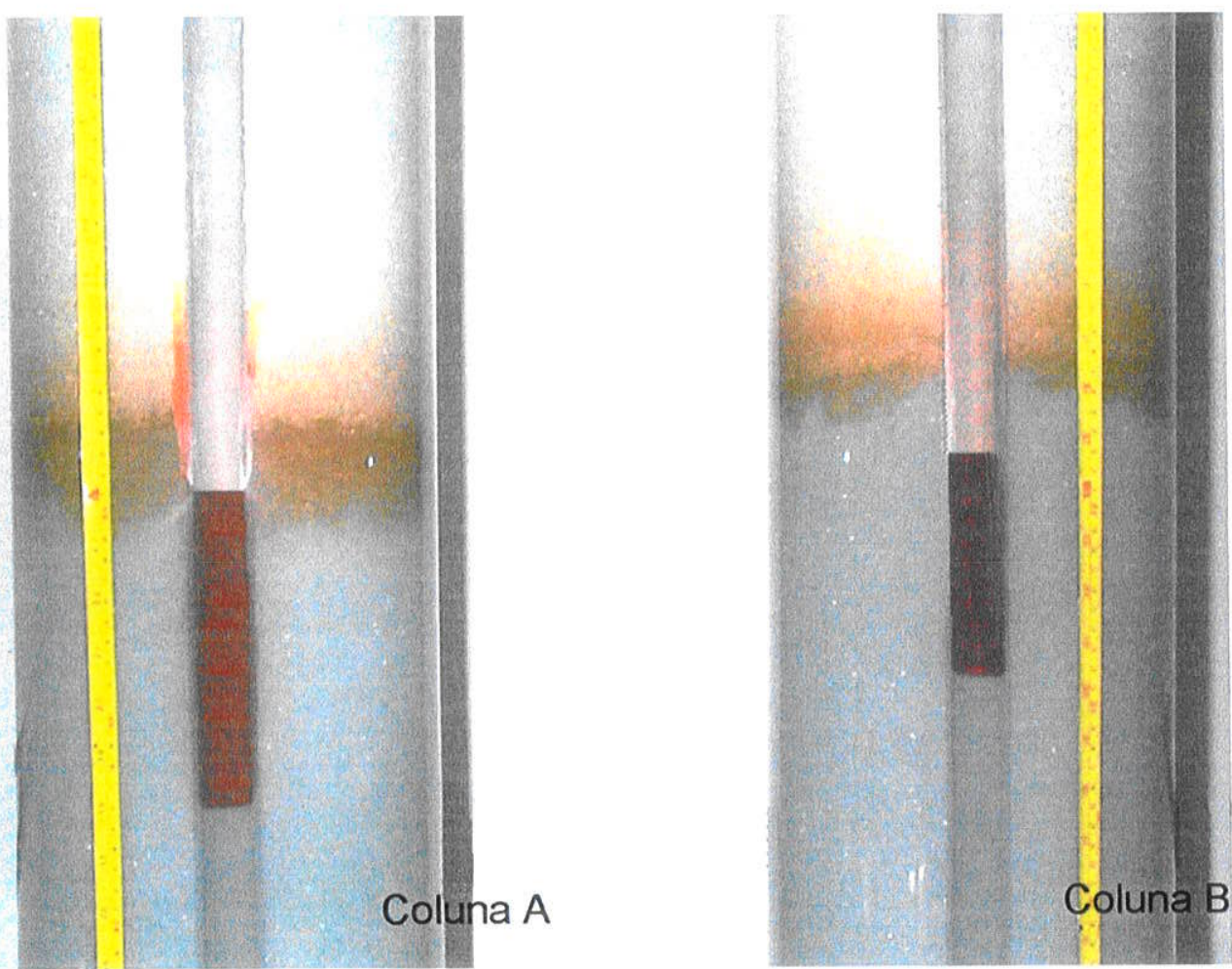

Figura 4.13 - Os níveis de combustíveis não obedecem o mesmo patamar. 
Estabilidade da lâmina de gasolina pura foi alcançada após 11 dias, enquanto o

\section{E-24 levou 38 dias}

Após um volume de $610 \mathrm{~mL}$ de gasolina pura e E-24 terem sido injetados em cada sistema, as colunas permaneceram em descanso, afastadas de qualquer pressão externa. Neste periodo houve arranjos internos entre as pressões de cada gasolina e o meio poroso, tendência ao equilibrio entre forças de gravidade, viscosidade e capilares. Além dos efeitos na solubilidade dos componentes hidrofilicos sofridos pela E-24. Ao final de 11 dias notou-se o equilibrio na Coluna $A$, verificada com a não variação da espessura da fase livre.

No entanto, como pode ser acompanhado pelas Figuras 4.14a e 4.14b, na Coluna B a espessura da lâmina de E-24 continuou aumentando até $\circ 38^{\circ}$ dia. A partir de então, as espessuras permaneceram estáveis com exceção da área ao redor do poço de monitoramento, que passou por diminuição gradativa até o $68^{\circ}$ dia de acompanhamento do experimento.

As duas gasolinas não somente apresentaram comportamentos distintos, no decorrer do experimento notou-se também características em comum quanto a disposição destas no meio:

Nas duas colunas, a lâmina no poço de monitoramento excedeu a espessura no meio contíguo, Figura 4.15:

A observação de cada coluna revela a diferença de espessura na lâmina de gasolina dentro do poço e sua extensão no meio poroso. A Tabela 4.2 mostra as medidas tomadas após 30 dias.

Tabela 4.2 - Medidas 'finais' das espessuras da fase livre na coluna A e B

\begin{tabular}{|c|c|c|}
\hline Combustiveis & Espessura no PM $(\mathrm{cm})$ & Espessura na franja $(\mathrm{cm})$ \\
\hline Gasolina pura & 15,6 & 6 \\
\hline E-24 & 12 & 3 \\
\hline
\end{tabular}

A razão entre as espessuras no poço de monitoramento e o meio não foi constante durante a migração:

No decorrer do experimento, na fase de injeção das gasolinas sobre a franja capilar e conseqüente infiltração dos combustíveis no meio poroso e poço de monitoramento, não foi 
verificada variação de espessuras da mesma ordem dos valores finais. A diferença entre as espessuras de 4 vezes, para a coluna $B$, e 2,6 vezes, na coluna $A$, não se manteve no período da injeção.

A diferença de 2,6 vezes entre a lâmina de gasolina pura no PM e meio poroso foi estabelecida após o equilíbrio entre a gravidade e forças capilares ter se firmado. Durante a injeção, as espessuras chegaram a diferir também por um fator 4 , o mesmo que rege a variação da E-24.
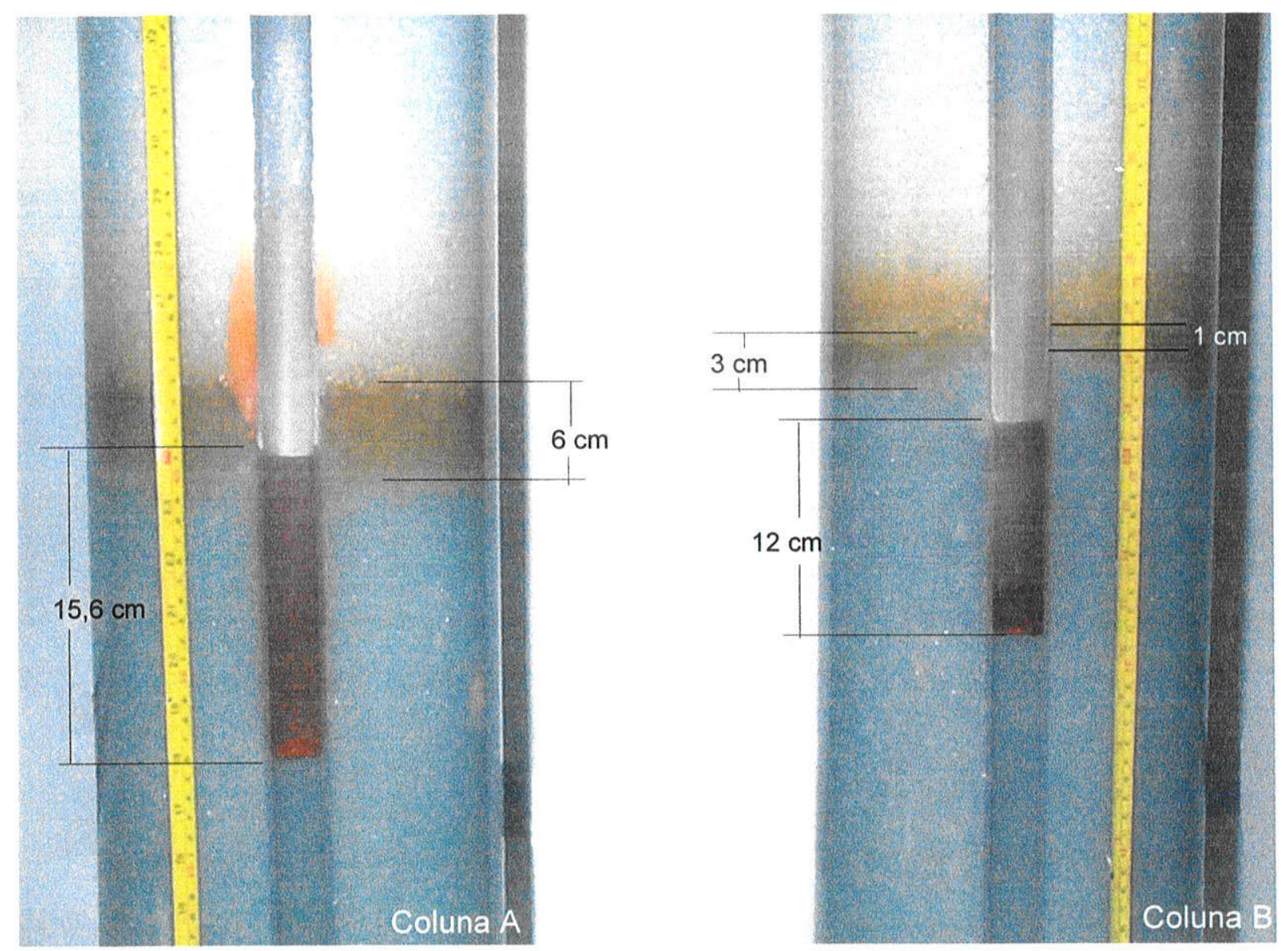

Figura 4.15 - Diferença entre as espessuras dos combustíveis no poço de monitoramento e meio poroso. 


\begin{tabular}{|c|c|c|}
\hline Coluna 1 & \multicolumn{1}{|c}{} \\
\hline $\mathrm{x}$ & $\mathrm{y}$ & $\mathrm{y}^{\prime}$ \\
\hline tempo(dias) & $\mathrm{P.M}$ & Franja Capilar \\
\hline 0,13 & 0,01 & 1,3 \\
\hline 0,19 & 11,1 & 3 \\
\hline 1 & 13,7 & 4,05 \\
\hline 2 & 14,8 & 4,05 \\
\hline 3 & 15 & 4,05 \\
\hline 4 & 14,9 & 4,05 \\
\hline 5 & 14,75 & 4,1 \\
\hline 6 & 14,9 & 4,1 \\
\hline 11 & 15,75 & 5,5 \\
\hline 14 & 15,8 & 5,6 \\
\hline 20 & 14,8 & 5,5 \\
\hline 21 & 14,95 & 5,5 \\
\hline 24 & 14,7 & 5,5 \\
\hline 26 & 15,4 & 5,5 \\
\hline 28 & 15,5 & 5,5 \\
\hline 33 & 14,85 & 6 \\
\hline 38 & 15,1 & 6 \\
\hline 39 & 15,6 & 6 \\
\hline 40 & 15,9 & 6 \\
\hline 41 & 15,8 & 6 \\
\hline 42 & 15,9 & 6 \\
\hline 46 & 15,7 & 6 \\
\hline
\end{tabular}

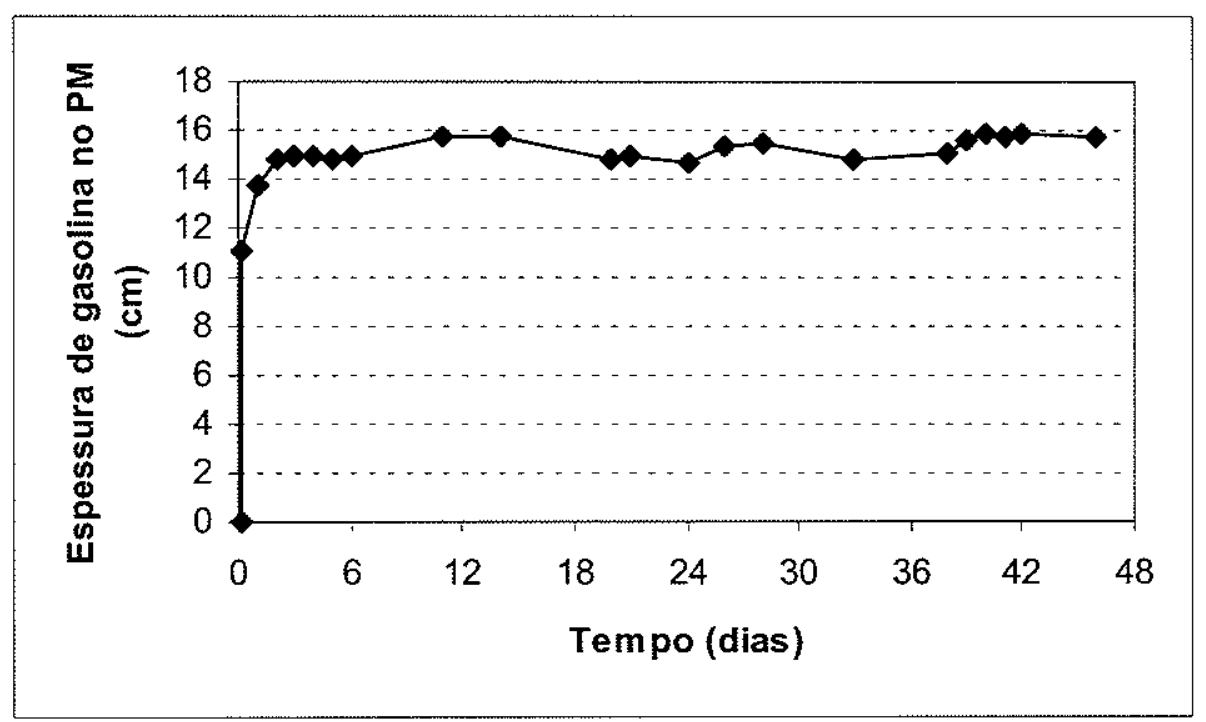

Figura 4.14a - Gráficos de acompanhamento da migração de gasolina pura. 
Coluna 2

\begin{tabular}{|c|c|c|}
\hline $\mathrm{x}$ & $\mathrm{y}$ & $\mathrm{y}^{\prime}$ \\
\hline tempo(dias) & P.M & Franja Capilar \\
\hline 0,13 & 0,02 & 1,5 \\
\hline 0,19 & 3,1 & 1,4 \\
\hline 1 & 7,1 & 2,9 \\
\hline 2 & 7 & 2,9 \\
\hline 3 & 7,1 & 2,9 \\
\hline 4 & 7,3 & 2,8 \\
\hline 5 & 7,6 & 3 \\
\hline 6 & 7,85 & 2,6 \\
\hline 11 & 9,4 & 2,8 \\
\hline 14 & 9,65 & 2,5 \\
\hline 20 & 9,7 & 2,3 \\
\hline 21 & 9,95 & 2,3 \\
\hline 24 & 10,3 & 2,3 \\
\hline 26 & 10,8 & 2,3 \\
\hline 28 & 11,5 & 2,3 \\
\hline 33 & 11,3 & 2 \\
\hline 38 & 12,3 & 2 \\
\hline 39 & 12,3 & 3 \\
\hline 40 & 12,1 & 3 \\
\hline 41 & 12,1 & 3 \\
\hline 42 & 11,9 & 3 \\
\hline 46 & 11,9 & 3 \\
\hline & & \\
\hline & & \\
\hline 14 & & 2 \\
\hline
\end{tabular}
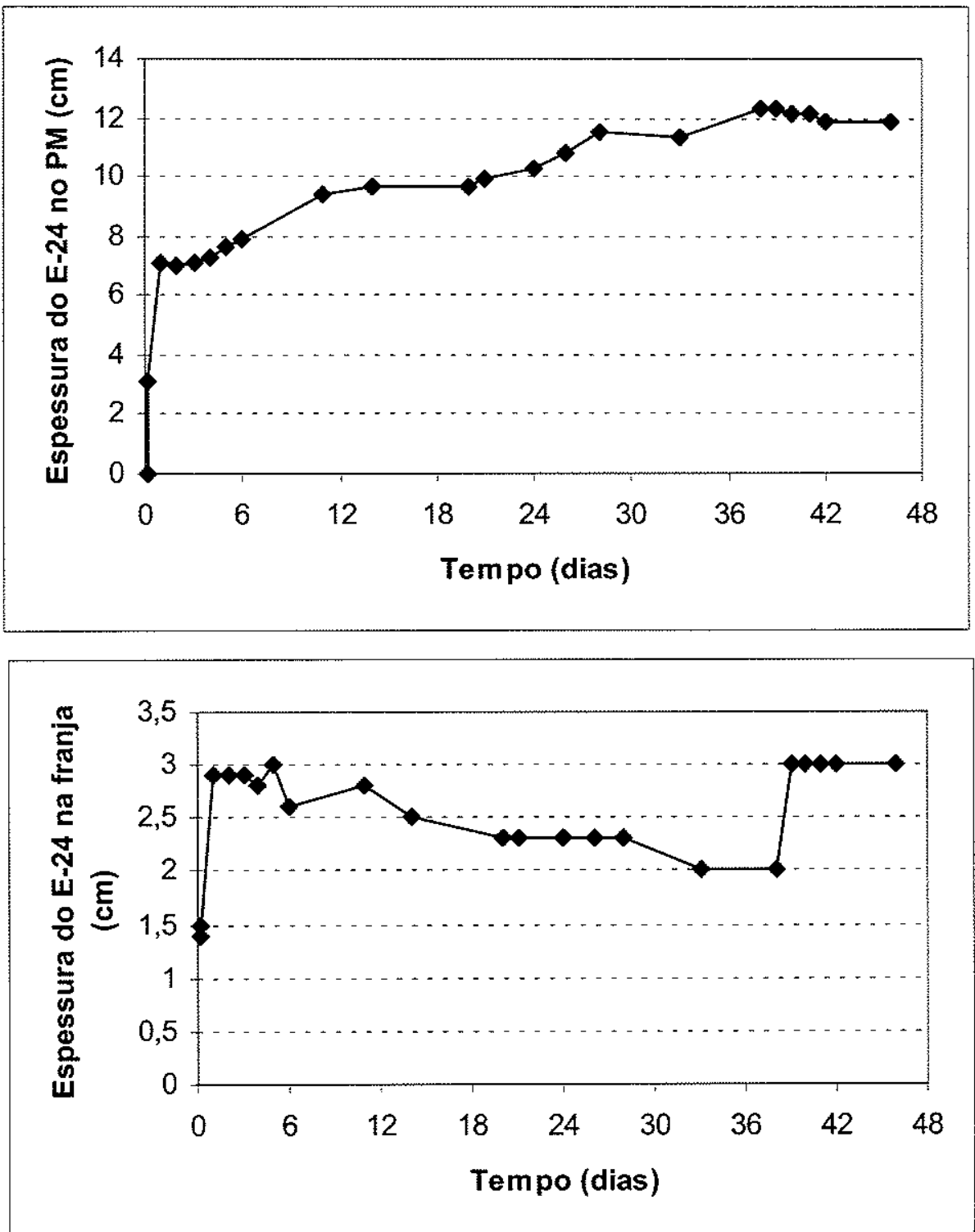

Figura 4.14b - Gráficos de acompanhamento da migração de E-24. 


\section{Capitulo 5 \\ RESULTADOS E DISCUSSÕES}

A migração dos dois tipos de combustível, gasolina pura e E-24 (24\% etanol e $76 \%$ gasolina), utilizados no experimento, foi acompanhada até ser mantido o equilibrio entre as espessuras do poço de monitoramento e da franja capilar. A comparação mostrou que o comportamento entre as gasolinas variou, mesmo que os procedimentos na construção dos sistemas, as condições do experimento e volumes injetados tenham sido idênticos.

Todo o experimento foi conduzido com observação da fase livre na área da franja capilar, com gradiente hidráulico zero e sem controle de temperatura.

Alguns pontos foram comuns aos dois combustiveis:

1) A lâmina no poço de monitoramento excedeu a espessura no meio contíguo:

A diferença entre a espessura da lâmina de combustivel no PM e no solo deve se ao resultado do balanço entre a gravidade e as forças capilares, sendo a força capilar característica do meio poroso e ausente no poço de monitoramento. No meio poroso, a gasolina migra por ação da pressão capilar, diferenças entre as tensões interfaciais e difusão, e por conseguinte conta-se com a tortuosidade do meio. Estes parâmetros não são observados no poço de monitoramento. No poço, apenas a pressão atmosférica age, sem interferência das forças capilares uma vez que o diâmetro do poço não configura um capilar.

Como a força capilar 'prende' a água nos poros formados pelos grãos do solo, a gasolina tem seu espaço reduzido pela presença da água. Mesmo empregando uma pressão maior a gasolina não consegue romper a adesão entre a água e os grãos do solo nos poros menores. No poço de monitoramento, a área superior ao nivel d'água é livre de forças ou capilares, havendo espaço para a gasolina se acumular.

Se o meio poroso fosse hidrofóbico todos os poros seriam ocupados pela gasolina e as espessuras de combustivel no PM e no solo seriam iguais. O mesmo ocorreria se o meio poroso fosse formado por sedimentos de granulometria grossa. Nos poros maiores a pressão capilar é menor, favorecendo a ocupação da gasolina.

Estes fatores descritos acima agem para ambos combustiveis, gasolina pura e E-24. Contudo para o E-24 a presença do etanol influencia também a diferença entre as espessuras da gasolina no PM e no solo.

Os hidrocarbonetos presentes na gasolina têm ligações químicas e propriedades físico-químicas distintas. A partição destes para água, vapor ou sólido do solo é regida por 
estas propriedades. No entanto a adição de etanol à composição da gasolina altera as propriedades e diminui as tensões interfaciais entre a gasolina e a água.

O efeito do etanol nas forças que agem na interface água-gasolina será explicada com observação da Figura 5.1.

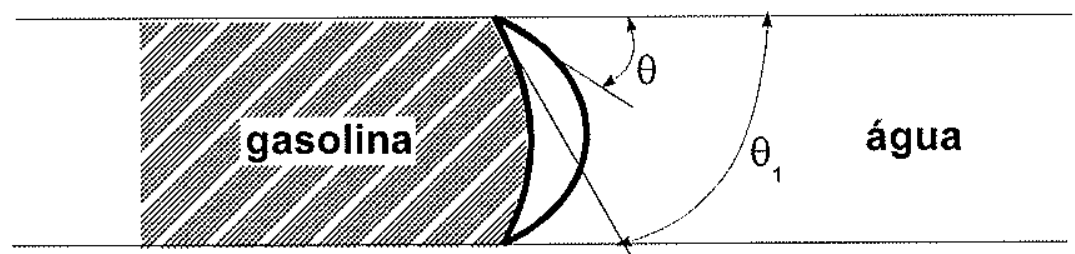

Figura 5.1 - Ângulo de contato entre gasolina pura e água $(\theta)$ no tubo capilar. Ângulo de contato modificado com adição de etanol $\left(\theta_{1}\right)$

O ângulo de contato entre a gasolina e a água é alterado, pois as forças de coesão das moléculas da gasolina sofrem com a adição do etanol. Ao partir-se para a água, após o contato do E-24 com a água, o etanol também altera as forças de coesão das moleculas da água. As ligações iônicas da água são "reorientadas", no que origina uma diminuição do menisco na interface E-24/água. Diminuição relativa ao menisco formado entre a gasolina pura e água. A atenuação das pressões internas da água e E-24 conduz a diminuição da pressão capilar.

A diluição do etanol na água resulta na diminuição do volume de E-24. Da mesma maneira há redução do volume de água presa nos poros. A água passa a formar uma fase aquosa composta de etanol e gasolina dissolvida. Isto resulta em uma menor concentração de moléculas de água nesta nova mistura (água, gasolina dissolvida e etanol). Entretanto, esta redução não é suficiente para expulsão de toda água trapeada, fazendo com que a água divida espaço poroso com a E-24. A E-24 tenderá a expandir-se sobre outros poros já que parte dos poros está ocupado por água. No poço, o combustível está concentrado sobre o NA, levando à diferença entre as espessuras do poço e solo.

$A$ adição do álcool na gasolina reduz a fração molar do BTEX na composição do combustivel. Entretanto, o etanol aumenta a solubilidade do BTEX presente na gasolina. Isto leva ao aumento de concentração destes elementos na pluma. Aliamse a presença de etanol na E-24 a maior migração do combustível para zona não saturada.

A migração do etanol para fase dissolvida foi correlacionada a menor espessura entre as lâminas na Coluna $B$ em relação a Coluna $A$. 
2) O combustivel migra para o poço de monitoramento somente depois de formada uma parte da fase livre e não imediatamente após a injeção:

$\mathrm{Na}$ Coluna $\mathrm{A}$, a gasolina pura antes de migrar para o $\mathrm{PM}$ formou $1,5 \mathrm{~cm}$ de fase livre valor equivalente a aproximadamente $170 \mathrm{~mL}$ de gasolina injetada. Isto se deve ao fluxo horizontal decorrer de áreas de mais alto potencial para potenciais mais baixos. As gasolinas, no início da injeção, acumulam-se em zona de pressão negativa e como o PM possui pressão zero não há potencial para incitar a migração. $O$ acúmulo progressivo faz desenvolver, na gasolina, pressão de carga suficiente para equilibrar a pressão negativa do meio, proporcionando pressão necessária a migração para o poço.

Em termos microscópicos, tem-se que o volume inicial de gasolina no meio tem pressão menor que a da água e maior que o do ar, fluidos preexistentes na parte superior da franja capilar. No início, a gasolina troca com o ar a condição de fluido não-molhante no meio poroso e passa a exercer na água pressão suficiente para iniciar a expulsão. $\mathrm{Na}$ interface água e gasolina cria-se uma tensão. As pressões internas de cada fluido, agindo na interface, e a pressão capilar nos poros agem de maneira a impulsionar a drenagem.

A forma adquirida pela gasolina em torno dos grãos do solo dependerá do grau de saturação entre os dois fluidos (água e gasolina), Capítulo 3. Esta forma pode ter frações pendulares desconexas ou não, que permitirá o acúmulo de maior massa de gasolina e consequentemente maior presão de carga para infiltração no poço.

Marinelli e Durnford (1996) explicaram a presença de gasolina na zona não saturada e ausência no poço de monitoramento através da análise das equações de van Genuchten e Brooks-Corey, que desprezam o efeito de histerese. Desta comparação aplicada para gradiente hidráulico zero, também característico desta dissertação, notou-se que a equação do modelo de Brooks-Corey previu que para haver migração o volume de gasolina no meio deve exceder o valor crítico Vo*. Este é o valor referente ao volume mínimo de gasolina acumulado no meio poroso para iniciar a migração do combustivel para o poço de monitoramento.

3) A razão entre as espessuras no poço de monitoramento e o meio não foi constante durante a migração:

Com o aumento gradual de pressão de carga da gasolina, tanto a franja capilar quanto o PM estavam sob recarga. O sistema não mostrava ainda um quadro de equilíbrio. A injeção gradativa de gasolinas proporcionou uma diferença pequena de espessuras entre as lâminas na franja capilar e no poço. Após a injeção notou-se que a configuração da diferença 
permaneceu sem apresentar alteração. Ou seja, na coluna A a lâmina de gasolina pura no PM era 2,6 vezes maior que a fase livre sobre a franja, e na coluna $B$ a lâmina de $E-24$ no PM era 4 vezes maior que a fase livre sobre a franja.

Em situação real, isto é similar a um vazamento não pontual, contínuo, onde o aumento da pressão de carga vai fornecendo constantemente produto para a fase livre e consequentemente para o poço. Disto se conclui que a estimativa do volume de combustível no poço somente pode ser feita quando a fonte for cessada.

\section{Os comportamentos das gasolinas diferiram quanto:}

1) As espessuras de combustivel formadas no PM e na franja capilar nas duas colunas diferiram. A lâmina de gasolina pura foi maior que a lâmina de E-24.

A diferença entre as espessuras das Colunas A e B deve-se ao efeito de co-solvência, propriedade do etanol vista no Capítulo 1. O aumento da solubilidade dos compotos solúveis da gasolina (benzeno o maior deles), promovido pelo etanol, impulsiona uma maior concentração destes para á agua. Esta migração para a fase dissolvida reduz a proporção dos compostos hidrofílicos na fase livre.

Do experimento de Oliveira (1997), a fase aquosa é composta de etanol e gasolina dissolvida e a fase gasolina é formada por etanol e água dissolvida. Pela inclinação das linhas de ligação do diagrama pseudoternário (Oliveira, 1997), tem-se que o etanol particiona-se preferencialmente para a fase água. $O$ etanol diminui a tensão interfacial entre a água e a E-24, dilui-se na água, ocupa mais poros que a gasolina pura. Isto resulta em diminuição do volume de E-24 e a consequente diminuição de espessura.

Por meio da Equação 4.2 obteve-se uma previsão da espessura da fase livre formada sobre a franja capilar a partir dos dados do poço de monitoramento. Com estes dados e observações das Colunas, não somente o cálculo pode ser realizado como pode-se comparar os resultados. Assim, tem-se

Tabela 5.1 - Espessuras da fase livre das gasolinas na franja capilar

\begin{tabular}{|l|c|c|}
\hline & Fase livre calculada & Fase livre real \\
\hline Gasolina pura & $3,9 \mathrm{~cm}$ & $6 \mathrm{~cm}$ \\
\hline E-24 & $3 \mathrm{~cm}$ & $3 \mathrm{~cm}$ \\
\hline
\end{tabular}


Verificou-se a precisão da Equação 4.2 no caso de estimativa da espessura da fase livre apenas no caso de gasolina comum (E-24).

2) $O$ fator 4, sugerido por de Pastrowisch, foi confirmado para o E-24. Para a gasolina pura este valor foi de 2,6:

O uso do fator de correção correto leva a precisão do volume de gasolina disposto como fase livre. A depender do combustivel vazado tem-se dois fatores de correção usualmente aplicados, 4 e 6 . Quando o produto for a gasolina comum o indice 4 satisfaz perfeitamente a correlação.

O cálculo da espessura verdadeira da fase livre baseada nas informações do poço de monitoramento obedeceu a taxa proposta por de Pastrowisch (1979). Foi de 4 vezes a diferença entre as espessuras da E-24 no poço de monitoramento e meio poroso contíguo. Para a gasolina pura o fator de correção foi 2,6.

A não coincidência entre os fatores para as duas gasolinas foi associada as diferentes condições de contorno que envolvem os dois sistemas. Mais condições de contorno envolvem o sistema da E-24. Além da presença dos fluidos imisciveis (gasolina e água) há o terceiro fluido, etanol, miscível tanto em água quanto em gasolina. Esta associação entre os fluidos e o meio poroso desencadeou mais relações de tensões com os grãos e redução das tensões interfaciais anteriores. Estas relações atingem o meio poroso, mas não são verificadas no poço de monitoramento, provocando a maior diferenciação na coluna $B$.

3) $\mathrm{Na}$ Coluna $\mathrm{B}$ antes e simultâneo à formação da fase livre notou-se uma ascenção de E-24 para zona não saturada:

Apesar da injeção dos combustíveis terem sido feitos diretamente sobre a franja capilar notou-se a presença de E-24 na zona não saturada durante o desenvolvimento da fase livre. Tal fato está ligado a pressão de vapor do combustível e a capilaridade.

Capilaridade: os volumes de gasolina injetados vão interagindo com a água a medida que se acumulam sobre a franja. Na migração do E-24 esta interação ocorreu antes e simultaneamente a formação da fase livre. Oliveira (1997) explica, pequenas diferenças de tensão interfacial causadas pela transferência de massa do etanol e água para a gasolina e vice-versa são responsáveis por pequenos glóbulos de gasolina moverem-se ascendentemente, contra o fluxo do fluido, mesmo para velocidades lineares acima de 2 ordens de magnitude maior que da água subterrânea. Oliveira (1997) continua suas observações com noções vistas em campo, ele observou que a diferença de densidade entre o etanol e água causaram a segregação do etanol da água com o etanol fluindo para as 
porções mais altas da zona saturada, movendo-se ascendentemente no sistema. Destas considerações pode-se inferir que o E-24 em contato com a água pode ter se despreendido desta e ter carreado os elementos miscíveis da gasolina até a zona não saturada.

Pressão: Pela lei de Raoult, a pressão total da mistura em E-24 é proporcional à soma dos produtos das pressões individuais da gasolina e etanol e suas frações molares na mistura. Assim temos:

$$
\begin{aligned}
& P_{E}-{ }_{24}=P V_{\text {gasolina }} . X_{\text {gasolina }}+P V_{\theta \text { tan ol }} . X_{t} \text { tan ol } \\
& \mathrm{PV}_{\text {gasolina }}=\text { entre } 413 \text { e } 775 \mathrm{mmHg} \\
& \mathrm{PV}_{\text {etanol }}=118,91 \mathrm{mmHg} \\
& X_{\text {etanol }}=0,24 \\
& \mathrm{X}_{\text {gasolina }}=0,76 \\
& \mathrm{P}_{\mathrm{E}-24}=342,4184 \mathrm{mmHg} \text { para } \mathrm{o} \text { valor de } 413 \mathrm{mmHg} \text { de } \mathrm{P}_{\text {gasolina }} \\
& 617,5384 \mathrm{mmHg} \text { para o valor de } 775 \mathrm{mmHg} \text { de } P v_{\text {gasolina }}
\end{aligned}
$$

Nota-se que a pressão de vapor da gasolina pura é maior que a pressão de vapor da E-24, de onde conclui-se que a concentração de combustível na zona não saturada na Coluna $A$ deve-se à pressão de vapor. No entanto, na coluna $B$ este fato está associado também ao efeito de capilaridade mais desenvolvido devido a menor tensão interfacial entre a E-24 e a água.

4) No decorrer da migração houve diferenças nas velocidades de fluxo das gasolinas.

As diferenças entre a gasolina pura e o a E-24 que explicam esta variação é a propriedade físico-química da viscosidade e a tensão interfacial entre o combustível e a água, agindo juntas em relação a mobilidade do produto.

A viscosidade da gasolina pura é menor que a da E-24. Uma maior viscosidade implica em menor mobilidade dos combustíveis líquidos no meio poroso.

O etanol presente na E-24 reduz a tensão interfacial entre a água e a gasolina. Oliveira (1997) mostra que a diminuição da tensão interfacial é proporcional a mobilidade da gasolina. A menor tensão interfacial no E-24 facilita a migração no meio poroso.

5) Estabilidade da lâmina foi alcançado para gasolina pura após 11 dias, enquanto o E-24 levou 38 dias.

A estabilidade do deslocamento é explicada através das linhas de isodensidades do diagrama pseudoternário de Oliveira (1997). 
O etanol parte-se para água carreando os compostos hidrofilicos da gasolina imediatamente após o contato e não migra de forma gradativa. $O$ refugo destes compostos permanece na gasolina e retoma sua solubilidade anterior visto que o tempo para alcance da estabilidade da lâmina da gasolina pura é menor que da E-24, implicando que os compostos misciveis continuam migrando para a água.

A lâmina de gasolina pura estacionou após 11 dias, enquanto o E-24 não alcançou equilibrio neste tempo. Tal fato pode estar aliado ao que foi visto por Oliveira (1997), Poulsen (1992) e Barker (1991), de que no tempo inicial o volume de oxigenado que parte-se para água levando o BTEX é grande. Após um tempo este valor é atenuado, o oxigenado aumenta a solubilidade do BTEX puro, produzindo uma alta concentração inicial dos BTEX para a água quando a concentração do oxigenado também é alta. Barker et al (1991) concluíram que a concentração restante do BTEX na gasolina (agora com índices baixos de oxigenados) diminui para níveis associados com gasolina pura.

Oliveira (1995) concluiu que após partição total do oxigenado para água a gasolina remanescente no aquífero terá composição diferenciada daquela injetada, principalmente quanto a presença de compostos solúveis.

7) Diferenças nas posições da lâmina de gasolina no PM em relação à franja capilar:

A correspondência entre as gasolinas em relação ao nível d'água anterior à contaminação pode ser acompanhada pela Tabela 5.2.

Tabela 5.2 - Posição das lâminas das gasolinas em relação ao nível d'água

\begin{tabular}{|l|c|c|c|c|}
\hline \multirow{2}{*}{} & \multicolumn{2}{|c|}{ Fração superior ao NA } & \multicolumn{2}{c|}{ Fração inferior ao NA } \\
\cline { 2 - 5 } & Calculado & Real & Calculado & Real \\
\hline E-24 & $27,54 \%$ & $4,17 \%$ & $72,46 \%$ & $95,83 \%$ \\
\hline Gasolina pura & $25,93 \%$ & $23,08 \%$ & $74,07 \%$ & $76,92 \%$ \\
\hline
\end{tabular}

A aplicação da Equação (4.5) foi verificada para a gasolina pura, mas distanciou-se muito das medidas reais no caso da $\mathrm{E}-24$.

Oliveira (1997) mostrou através de linhas de isodensidades plotadas em diagrama pseudoternário que as misturas gasolina, água e etanol que caem na região de fase única do diagrama são sempre mais densas que a fase original da gasolina.

Volume e densidade para substâncias antes e depois da mistura com a água, Oliveira (1997): 
A densidade "final" da mistura água e etanol torna-se maior que as densidades calculadas com base nos volumes em separado das substâncias. Da mesma maneira, o volume "final" é menor que a soma das duas fases em separado. Seguindo este raciocínio alia-se o maior rebaixamento da E-24 a maior densidade das misturas.

A posição da fase livre no meio deve levar em conta também a litologia da área para o cálculo da franja capilar, local de acumulação do combustível liberado no subsolo. Ressaltase que a posição do nível de combustível no poço também não é refletido no meio. Vale a relação de porcentagens em relação ao nível d'água (Oliveira, 1997).

A elevação da fase livre de E-24 ao redor do poço de monitoramento, Figura 4.12, deve ser descontada na estimativa da posição da fase livre. 


\section{Capítulo 6 \\ CONCLUSÕES E RECOMENDAÇÕES}

\section{1 - Conclusões}

Através da comparação entre as duas colunas pode-se ter o caráter diferencial entre o comportamento da gasolina pura e da mistura utilizada como combustivel no Brasil, o (E-24).

Por meio desta análise, resume-se (para um sistema estático e homogêneo):

Nas duas colunas, a lâmina no poço de monitoramento excedeu a espessura no meio contíguo. As espessuras de gasolina pura formadas no PM e meio poroso foram maiores que as espessuras formadas pela E-24.

A diferença entre a espessura da lâmina de combustivel no PM e no solo deve se ao resultado do balanço entre a gravidade e as forças capilares, sendo a força capilar característica do meio poroso e ausente no poço de monitoramento. Condições existentes tanto na coluna $A$, com gasolina pura, quanto na coluna $B$, com E-24.

As condições de contorno que regem o sistema de três fluidos (água/gasolina/etanol) são mais complexas que o sistema de gasolina e água. A presença do etanol influencia também a diferença entre as espessuras da gasolina no poço de monitoramento e no solo.

No decorrer da migração houve diferenças nas velocidades das gasolinas na formação da fase livre.

As diferenças entre a gasolina pura e o a E-24 que explicam esta variação é a propriedade físico-química da viscosidade e a tensão interfacial entre o combustivel e a água agindo juntas em relação a mobilidade do produto. Uma maior viscosidade implica em menor mobilidade dos combustiveis líquidos no meio. $O$ etanol presente na E-24 reduz a tensão interfacial entre a água e a gasolina, provocando também uma maior mobilidade do combustível.

Estabilidade da lâmina foi alcançada para gasolina pura após 11 dias, enquanto o E-24 levou 38 dias

O etanol parte-se para água carreando os compostos hidrofilicos da gasolina imediatamente após o contato e não migra de forma gradativa. O refugo destes compostos permanece na gasolina e retoma sua solubilidade anterior visto que o tempo para alcance da estabilidade da lâmina da gasolina pura é menor que da E-24, implicando que os compostos misciveis continuam migrando para a água. 
O combustível migra para o poço de monitoramento somente depois de formada uma parte da fase livre e não imediatamente após a injeção.

As gasolinas, no início da injeção, acumulam-se em zona de pressão negativa e como o PM possui pressão zero não há potencial para incitar a migração. $\mathrm{O}$ acúmulo progressivo de gasolina faz desenvolver no combustível pressão de carga suficiente para equilibrar a pressão negativa do meio proporcionando pressão necessária a migração para o poço.

A razão entre as espessuras no poço de monitoramento e o meio não foi constante durante a migração:

Durante a injeção de gasolina pura e E-24 as diferenças entre as espessuras do combustível no poço e solo foram menores que os valores medidos com o final da injeção, no periodo de equilíbrio. Com o aumento gradual de pressão de carga da gasolina, tanto a franja capilar quanto o PM estavam recebendo produto, o sistema não mostrava ainda um quadro de equilíbrio. A carga gradativa nos dois ambientes proporcionou uma pequena diferença de espessuras entre as lâminas no mesmo sistema

\section{2 - Recomendações}

Baseados nas diferenças existentes no poço de monitoramento e meio poroso, comprovadas nesta dissertação, recomenda-se que:

1) os dados provenientes dos poços de monitoramento devam ser corrigidos para o fator correspondente ao combustível vazado. Isto devido a não projeção da lâmina contida no poço de monitoramento para o meio poroso;

2) o volume de E-24 a ser recuperada seja calculado observando-se o efeito cosolvente do etanol, comportamento distinto de outros combustiveis;

3) para medida de profundidade e presença da fase livre no aqüifero, se considere os efeitos de pressões negativas a que a gasolina está submetida na zona não saturada;

4) para maior precisão das medidas do poço de monitoramento, deve-se conter a fonte de contaminação. Isto, visto que a recarga simultânea de gasolina para o poço de monitoramento e franja capilar não oferece o fator de correção exato. 


\section{REFERÊNCIAS BIBLIOGRÁFICAS}

Abdul, A.S.; Gillham, R.W. (1984) Laboratory Studies of Effects of Capillary Fringe on Streamflow Generation, Water Resources Research, vol. 20, $n^{\circ} 6$, pages 691-698, june

Abdul, S. A.; Kia, S. F.; Gibson, T. L. (1989) Limitations of Monitoring Wells for the Detection and Qualification of Petroleum Products in Soils Aquifers. Ground Water Monitoring Research, Spring, pp 90-99.

Adams, T. V.; Hampton, D. R. (1992) Effects of capillarity on DNAPL thickness in wells and adjacent sands. Subsurface Contamination by Immiscible Fluids , Weyer(ed.) Balkema, Rotterdam, ISBN, pp 131-138.

Al-Sulaimi, J.; Wiswanathan, M.N.; Székely, F. (1993) Effect of oil pollution on fresh grondwater in Kuwait. Environmental Geology. Vol. 22, no 3, pg. 246-256.

Barker, J. F.; Hubbard. C. E.; Lemon, L. A.; Vooro, K. A. (1991) The Influence of Methanol in Gasoline Fuels on the Formation of Dissolved Plumes, and on the Fate and Natural Remediation of Methanol and BTEX Dissolved in Groundwater, Editors Edward J. Calabrese \& Paul T. Kostecki, Hydrocarbon Contaminated Soils and Groundwater, vol. 2, Lewis Publishers

Barker, J.F.; Patrick, G.C (19) The fate and persistence of aromatic hydrocarbons dissolved in groundwater: results from controlled field experimrents

Bear, J (1972) Dynamics of Fluids in Porous Media, Dover Publications, Inc., New York, $764 \mathrm{p}$.

CETESB (1990) Compilação de Padrões Ambientais. Manual de concentrações de poluentes orgânicos e inorgânicos 
Chatzis, I e Dullien, F. A. L. (1983) Dynamic Immiscible Displacement Mechanisms in Pore Doublets: theory versus experiment. J. Colloid Interface Sci. 91, 199p.

Dakin, R. A.; Holmes A.T.; Tiplady, D. J. (1992) Practical aspects of hydrogeology studies for hydrocarbon migration in British Columbia, Subsurface contamination by immiscible fluids, K. U. Weyer editor, Proceedings of the international conference on subsurface contamination by immiscible fluids / Calgary / Canada / 18-20 abril 1990.

de Pastrovish, T. L.; Baradat, Y.; Barthel, R.; Chiarelli, A.; Fussell, D. R. (1979) Protection of Groundwater from Oil Pollution, CONCAWE, Report 3/79, Den Haag, Netherlands.

Dullien, F. A. L. (1992) Porous Media, Fluid Transport and Pore Structure $2^{\circ}$ edição. Academic Press, Inc. San Diego, California, 455p.

Fetter, C. W. (1992) Contaminant Hydrogeology. Prentice-Hall, Inc. Englewood Cliffs, New Jersey, $452 p$.

Freeze, R. A; Cherry, J A (1979) Groundwater. Prentice-Hall, Inc. Englewood Cliffs, New Jersey, 604p.

Gillham, R. W. (1984) The capillary fringe and its effect on water-table response, Journal of Hydrology, 67: 307-324.

Graham, D. N.; Schiegg, H. O.; McBride, J. F. (1992) Experimental simulation of threephase flow in porous media, Subsurface contamination by immiscible fluids, K. U. Weyer editor, Proceedings of the international conference on subsurface contamination by immiscible fluids / Calgary / Canada / 18-20 abril 1990.

Hartz, M. J.; Overcamp, T. J. (1996) The Geometry of Nonwetting Liquids in the Unsatureted Zone, Ground Water, vol. $34, n^{\circ} 5$, September-October. 
Hunt, J. R.; Sitar, N.; Udell, K. S. (1988) Nonaqueous Phase Liquid Transport and Cleanup, 1. Analysis of Mechanisms.

Lal, R.; Bridge, B. J.; Collis-George, N. (1970) The Effect of Column Diameter on the Infiltration Behaviour of a Swelling Soil, Aust. J. Soil Res., 8, 185-193.

Larson, R.G.; Davis, H. T.; Scriven, L. E. (1981) Displacement of Residual Nonwetting Fluid from Porous Media, Chemical Engineering Science, vol. 36, pp.75-85.

Larson, R.G.; Scriven, L. E.; Davis, H. T. (1981) Percolation Theory of Two Phase Flow in Porous Media, Chemical Engineering Science, vol. 36, pp-57-73.

Libardi, P.L.. (1995) Dinâmica da Água no Solo, Piracicaba. 497pp.

Mackay, D. M. \& Cherry, J.A (1989) Groundwater contamination: limitations of pump-andtreat remediation. Environmental science \& technology, vol. 23, no 6, pp. 630-636.

Marinelli, F.; Durnford, D. S. (1996) LNAPL thickness in monitoring wells considering hysteresis and entrapment, Ground Water, vol. 34, no 3, 405-414.

Morrow, N. R. (1970) Physics and Thermodynamics of Capilary. Chapter in Flow Through Porous Media. American Chemical Society Washington D.C. pg. 103-128.

Pinal et al (1990) Environmental Science and Technology, 24, pp. 639-647.

Schiegg, H. O. e McBride, J. F. (1987) Laboratory setup to study two-dimensional multiphase flow in porous media. In Proceedings of Petroleum Hydrocarbons and Organic Chemicals in Ground Water Conference, Houston, Texas, p. 371-385.

Schwille, F. (1988) Dense chlorinated solvents in porous and fractured media - model experiments. J. F. Pankow (trans.). Chelsea, Michigan. Lewis Publishers, 146p. 
Silveira, A L.da; Louzada, J.A.; Beltrame, L. (1992) Infiltração e armazenamento no solo. In Hidrologia, $1^{\text {a }}$ edição, São Paulo, Carlos Tucci ed., Editora da Universidade UFRGS/ Edusp/ABRH, pgs. 335-372.

Simmons, C.S; McBride, J. F.; Carry, J. W.; Lenhard, R. J. (1992) Organic liquid infiltration into unsaturated porous media. Subsurface contamination by immiscible fluids, K. U. Weyer editor, Proceedings of the international conference on subsurface contamination by immiscible fluids / Calgary / Canada / 18-20 abril 1990.

Stumm, W.; Morgan, J. J. (1970) Aquatic Chemistry, $2^{\circ}$ Ed., Toronto: John Wiley \& Sons.

Poulsen, M.; Lemon, L.; Barker, J. F. (1992) Dissolution of Monoaromatic hydrocarbons into groundwater from gasoline-oxygenate mixtures. Environmental science \& technology, vol. 26.

Oliveira, E. (1992) Contaminação de aqüíferos por hidrocarbonetos. São Paulo, pg.132 dissertação de mestrado, Instituto de Geociências, USP.

Oliveira, E. (1997) Ethanol flushing of gasoline residuals - microscale and field scale experiments, Tese de doutorado em Ciências da Terra, Universidade de Waterloo, Canada.

Oliveira, I. B. de (1995) Infiltration of organic liquids in unsaturated sands: comparison of experimental measurements with scaled and unscaled analytical solution. Tese de doutorado em Filosofia (Engenharia ambiental) Universidade de Michigan.

Rizzuti, L; Augugliaro, V.; LO Cascio, G. (1981) The influence of the liquid viscosity on the effective interfacial area in packed columns. Chemical Engineering Science. Vol.36, pp. 973-978. 
Teja, A S.; Rise, P. (1980) The Measurement and Prediction of the Viscosities of some Binary Liquid Mixtures Containing n-hexane. Chemical Engineering Science. Vol 36, pp.710.

Willians, M. M. (1996) Properties of Light Non-Aqueous Phase Liquids and Detection Using Commonly Applied Shallow Sensing Geophysical Techniques. Canada.

Wilson, J. L. (1992) Pore scale behavior of spreading and non-spreading organic liquids in the vadose zone, Subsurface contamination by immiscible fluids, K. U. Weyer editor, Proceedings of the international conference on subsurface contamination by immiscible fluids / Calgary / Canada / 18-20 abril 1990. 